
Not for reproduction, distribution or commercial use.

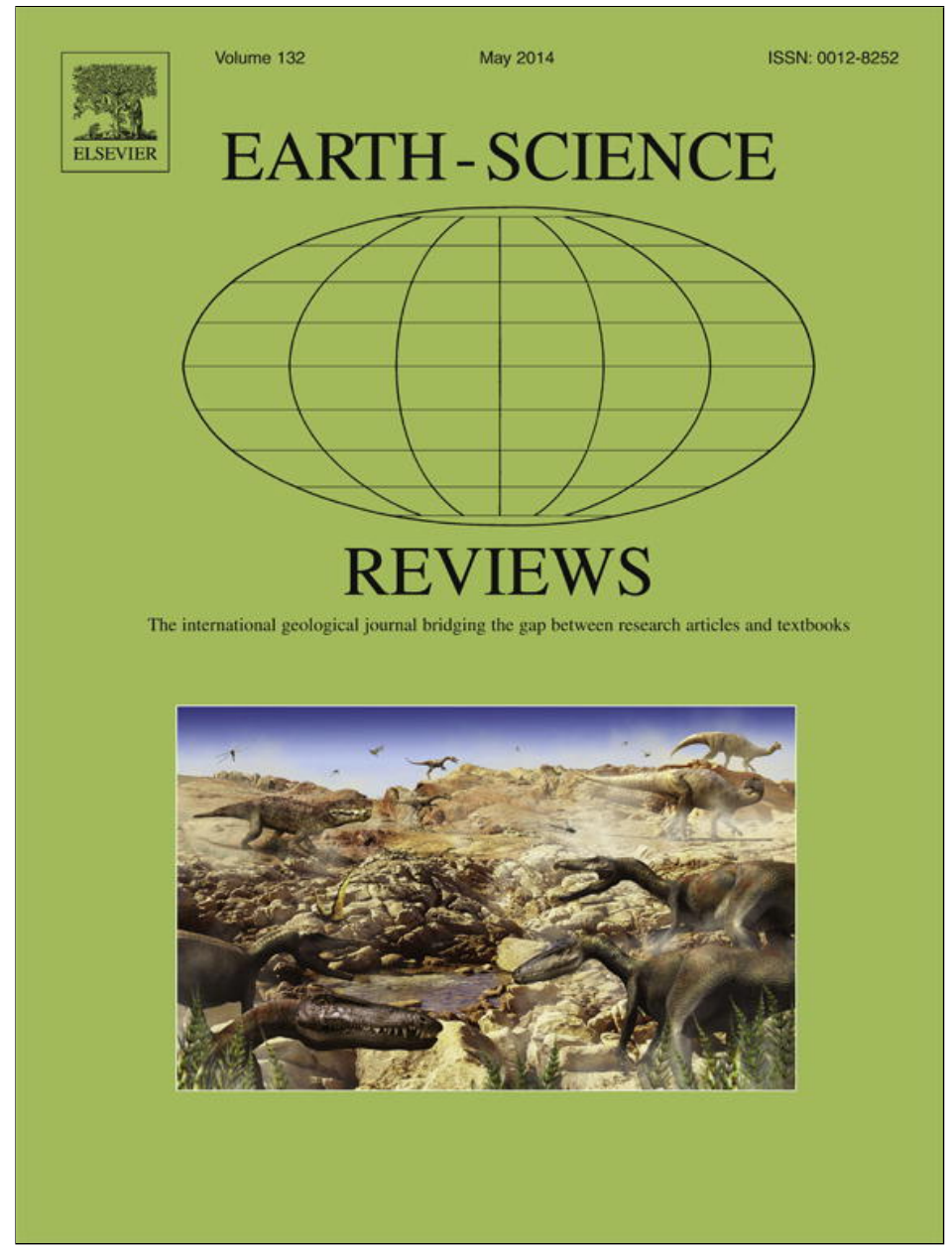

This article appeared in a journal published by Elsevier. The attached copy is furnished to the author for internal non-commercial research and education use, including for instruction at the authors institution and sharing with colleagues.

Other uses, including reproduction and distribution, or selling or licensing copies, or posting to personal, institutional or third party websites are prohibited.

In most cases authors are permitted to post their version of the article (e.g. in Word or Tex form) to their personal website or institutional repository. Authors requiring further information regarding Elsevier's archiving and manuscript policies are encouraged to visit:

http://www.elsevier.com/authorsrights 
Review

\title{
Coastal staircase sequences reflecting sea-level oscillations and tectonic uplift during the Quaternary and Neogene
}

\author{
Kevin Pedoja a,b,c,*, Laurent Husson ${ }^{\mathrm{d}, \mathrm{e}}$, Markes E. Johnson ${ }^{\mathrm{f}}$, Daniel Melnick ${ }^{\mathrm{g}}$, Cesar Witt ${ }^{\mathrm{h}}$, Stéphane Pochat ${ }^{\mathrm{e}}$, \\ Maëlle Nexer ${ }^{\mathrm{a}, \mathrm{b}, \mathrm{c}}$, Bernard Delcaillau ${ }^{\mathrm{a}, \mathrm{b}, \mathrm{c}}$, Tatiana Pinegina ${ }^{\mathrm{i}}$, Yohann Poprawski ${ }^{\mathrm{a}, \mathrm{b}, \mathrm{c}}$, Christine Authemayou ${ }^{\mathrm{j}}$, \\ Mary Elliot ${ }^{\mathrm{e}}$, Vincent Regard ${ }^{\mathrm{j}, \mathrm{k}, \mathrm{l}, \mathrm{m}}$, Franck Garestier ${ }^{\mathrm{a}, \mathrm{b}, \mathrm{c}}$
}

a Normandie Univ, France

b UCBN, M2C, F-14000 Caen, France

c CNRS, UMR 6143 M2C, F-14000 Caen, France

d CNRS UMR 6112, LPG Nantes, France

e CNRS UMR 5275, ISTerre, Grenoble, France

${ }^{\mathrm{f}}$ Geosciences Department, Williams College, MA 01267 USA

$\mathrm{g}$ Institute of Earth and Environmental Science, University of Potsdam, 14476 Potsdam, Germany

h CNRS UMR, 8217 Géosystèmes, Bâtiment SN5, Avenue Paul Langevin, 59655 Villeneuve D'Ascq Cedex, France

${ }^{\mathrm{i}}$ Institute of Volcanology and Seismology, FED RAS, Petropavlovsk-Kamchatsky 683006, Russia

${ }^{j}$ Université de Brest (UBO) and CNRS, UMR 6538, Domaines Océaniques, Institut Universitaire Européen de la Mer, 29238 Plouzané, France

k Université de Toulouse, UPS (OMP), LMTG, 14 Av Edouard Belin, F-31400 Toulouse, France

${ }^{1}$ IRD, LMTG, F-31400 Toulouse, France

m CNRS, LMTG, F-31400 Toulouse, France

\section{A R T I C L E I N F O}

\section{Article history:}

Received 17 May 2013

Accepted 24 January 2014

Available online 7 February 2014

\section{Keywords:}

Cenozoic

Coastal sequence of shorelines

Strandlines

Rasa

Geodynamic

\begin{abstract}
A B S T R A C T
Many coasts feature sequences of Quaternary and Neogene shorelines that are shaped by a combination of sealevel oscillations and tectonics. We compiled a global synthesis of sea-level changes for the following highstands: MIS 1, MIS 3, MIS 5e and MIS 11. Also, we date the apparent onset of sequences of paleoshorelines either from published data or tentatively extrapolating an age for the uppermost, purported oldest shoreline in each sequence. Including the most documented MIS 5e benchmark, we identify 926 sequences out of which 185 also feature Holocene shorelines. Six areas are identified where elevations of the MIS 3 shorelines are known, and 31 feature elevation data for MIS 11 shorelines. Genetic relationships to regional geodynamics are further explored based on the elevations of the MIS 5e benchmark. Mean apparent uplift rates range from $0.01 \pm 0.01 \mathrm{~mm} / \mathrm{yr}$ (hotspots) to $1.47 \pm 0.08 \mathrm{~mm} / \mathrm{yr}$ (continental collision). Passive margins appear as ubiquitously uplifting, while tectonic segmentation is more important on active margins. From the literature and our extrapolations, we infer ages for the onset of formation for 180 coastal sequences. Sea level fingerprinting on coastal sequences started at least during mid Miocene and locally as early as Eocene. Whether due to the changes in the bulk volume of seawater or to the temporal variations in the shape of ocean basins, estimates of eustasy fail to explain the magnitude of the apparent sea level drop. Thus, vertical ground motion is invoked, and we interpret the longlasting development of those paleoshore sequences as the imprint of glacial cycles on globally uplifted margins in response to continental compression. The geomorphological expression of the sequences matches the amplitude and frequency of glacial cyclicity. From middle Pleistocene to present-day, moderately fast $(100,000$ yrs $)$ oscillating sea levels favor the development of well identified strandlines that are distinct from one another. Pliocene and Lower Pleistocene strandlines associated with faster cyclicity (40,000 yrs) are more compact and easily merge into rasas, whereas older Cenozoic low-frequency eustatic changes generally led to widespread flat-lying coastal plains.
\end{abstract}

\section{Contents}

1. Introduction . . . . . . . . . . . . . . . . . . . . . . . . . . . . . . . . . . . . . . . 14

2. The "sea-level barcode" . . . . . . . . . . . . . . . . . . . . . . . . . . . . . . . . . . . 14

\footnotetext{
* Corresponding author at: UMR M2C / Université de Caen2-4 rue des Tilleuls, 14000 Caen, France. Tel.: +332315657.
}

E-mail address: kevin.pedoja@unicaen.fr (K. Pedoja). 


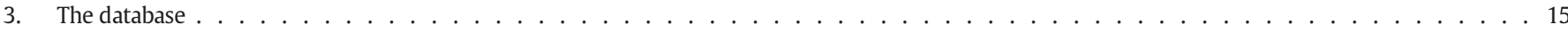

4. Sequences of strandlines through space and time $\ldots \ldots \ldots \ldots \ldots$

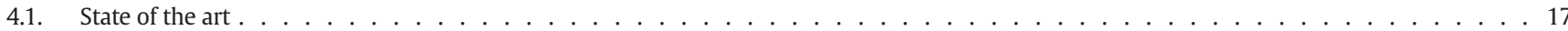

4.2. Geographical distribution . . . . . . . . . . . . . . . . . . . . . . . . . . . . . . . . . . . . . . . . . . . . . . . . . . . . . . 21

4.3. The lower part of the sequences, Holocene to Middle Pleistocene, MIS 1 to MIS 19 . . . . . . . . . . . . . . . . . . . . . . . . 21

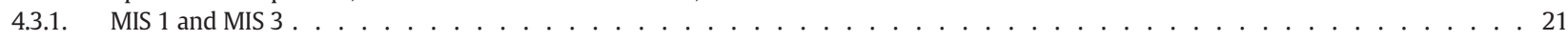

4.3.2. Last interglacial, MIS $5 \mathrm{e} \ldots \ldots \ldots \ldots \ldots \ldots$

4.3.3. Middle Pleistocene, MIS 7 to MIS $19 \ldots \ldots \ldots \ldots \ldots$

4.4. The upper part of the sequences: Lower Pleistocene-Eocene . . . . . . . . . . . . . . . . . . . . . . . . . . . . . . 26

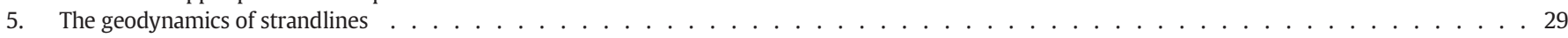

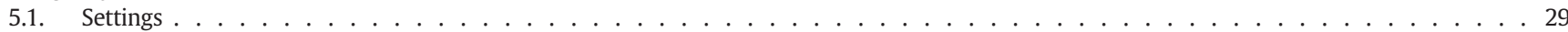

5.2. $\quad$ Results . . . . . . . . . . . . . . . . . . . . . . . . . . . . . . . 29

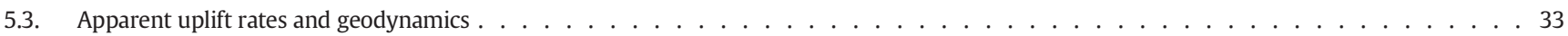

6. Places for future refinements $\ldots \ldots \ldots \ldots \ldots \ldots$

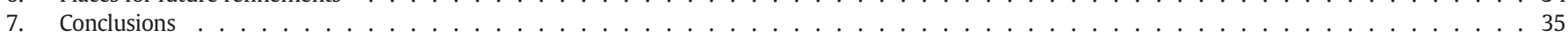

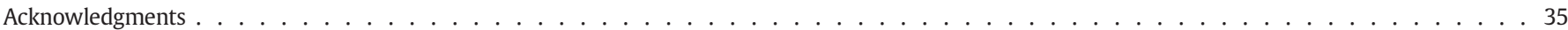

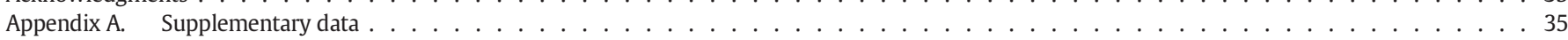

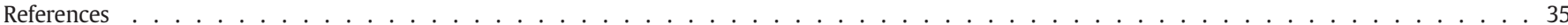

\section{Introduction}

Ever since the seminal contribution of Lajoie (1986), geomorphologists have gained a better understanding on the relationship between late Pliocene and Quaternary sea-level fluctuations and marine strandlines (i.e. abandoned or relict marine shorelines). The latter are widespread tectonic markers recorded by upper Cenozoic geomorphology. Preserved on a regional to global scale, coastal geomorphology often mirrors regional patterns (Inman and Nordstrom, 1971) and even global tectonic patterns (Pedoja et al., 2011). The major aim of the present work is to further disentangle these relationships in time and space. We have compiled a database (reference for real-time updated online version at the end) for sequences that entail elevation data on paleoshorelines associated with the interglacial highstands that bracket the last interglacial maximum - Marine Isotope Stage (MIS) 5e (updated from Pedoja et al., 2011). We have added the elevations of MIS 1 , MIS 3 and MIS 11 shorelines to the analysis and further tried to delimit the sequences in order to find the age of the older and higher strandlines in the succession. Thus, we have collected additional data on elevations and ages of Neogene and Paleogene shorelines from the literature. For the most poorly constrained sequences, we propose an age based on the maximum elevation of the sequence by crudely extrapolating a constant uplift rate derived from the elevation of the MIS 5e datum. A byproduct of our work is an exploration of the regional geodynamic settings of shorelines undergoing vertical ground motion. As a starting point, we updated our primary database on MIS 5e benchmarks (see Pedoja et al., 2011). Then, we analyzed our results with respect to the long-term relevance of observed uplift rates, location of long-lasting sequences of paleocoasts, and geographic setting.

\section{The "sea-level barcode"}

Sequences or flights of strandlines or paleoshorelines (e.g. marine terraces, coral reef terraces, notches), generally running parallel to the present-day shoreline, shape the majority of coasts worldwide (Pedoja et al., 2011). Similarly to their modern counterparts, three main types of paleoshorelines can be differentiated: erosional (e.g. marine terraces, notches), depositional (e.g. beach-ridges) and constructional (e.g. coral reef terraces). See supplementary material in Pedoja et al. (2011) for geomorphic descriptions and examples.

Several processes generate emerged sequences of ancient shorelines (see Fig. 1 for a graphical synthesis of geomorphic factors that include number of levels, heights, etc.). During each sea-level stand (successive highstands in particular), multiple processes may be active at the same time but their ability to efficiently and persistently shape the landscape is variable. Consequently, these processes are unevenly preserved or recorded in the past. Although noticeable at human time scales, storms are short-term events. As in the case of any seasonal cycle, their effects on coastlines are generally erased from the geological record almost instantaneously. In turn, co-seismic uplift might be more pervasive. In light of the stabilization of modern sea level (Ota and Yamaguchi, 2004), paleocoasts associated with co-seismic uplift are well recognized for the last 5-6 ka (i.e. since the mid-Holocene). Of course, co-seismic deformation of strandlines is not associated only with sea-level highstands, as opposed to postglacial rebound (sometimes referred to as glacio-hydro-isostatic adjustment GIA), the rhythm of which is dictated by sea-level oscillations due to ice melting. Sea-level highstands associated with glacial/interglacial cycles are well recognized at least during the Quaternary. Indeed, such cycles were initially identified as part of the most recent geological period affected by glacial events and bracketed at $\sim 2.6 \mathrm{Ma}$, but possibly may extend further into the past in association with the onset of earlier glaciations during the Cenozoic (as for instance during the buildup of the ice sheet in East Antarctica, e.g. Stocchi et al., 2013). Such sea-level oscillations interact with tectonic uplift that promotes the preservation of emerged fossil strandlines.

Only tectonic uplift in concert with sea-level oscillations can shape the staircase geometry to produce coastlines with steps of coeval ages. Regardless of its duration, tectonic uplift lends itself to the preservation of well-developed sequences of geomorphic markers associated with past shorelines (e.g. notch, shoreline angle, reef crest, beach deposits, etc.). For previous authors (Lajoie, 1986; Pirazzoli, 1994), the interplay between glacio-eustatic sea-level oscillations and coastal vertical uplift operated from the late Pliocene onwards, but current knowledge about Cenozoic sea-level history and coastal sequences improved since these fundamental contributions and the onset of the phenomenon remain unclear.

For at least sixty years (e.g. since Zeuner, 1952), emerged coastal sequences were interpreted as having formed during separate highstands of interglacial stages that correlate to Marine Isotopic Stages (MIS) (e.g. James et al., 1971; Chappell, 1974; Bull, 1985; Lajoie, 1986; Ota, 1986). Where positive vertical ground motion (i.e. uplift) is sufficiently fast ( > 1.2 mm/yr, see below), interstadial oscillations (e.g. MIS 3) may emerge at present-day, even if sea level positions stand tens of meters below present-day sea level (e.g. $50 \mathrm{~m}$ in Waelbroeck et al., 2002). The timing and duration of the last interglacial maximum (MIS 5e) is better known than those of other interglacial periods (e.g. Winograd et al., 1997; Waelbroeck et al., 2002; Siddal et al., 2006; Dutton et al., 2009; Rohling et al., 2009). Yet, commonly preserved paleoshorelines in worldwide sequences include those related to MIS 7, 9 and 11 (e.g. Imbrie et al., 1984; this study). MIS 11 is generally regarded as the best analog for the Holocene, because insolation during MIS 11 was similar to that of the recent past (Berger and Loutre, 2002). Uncertainties on 


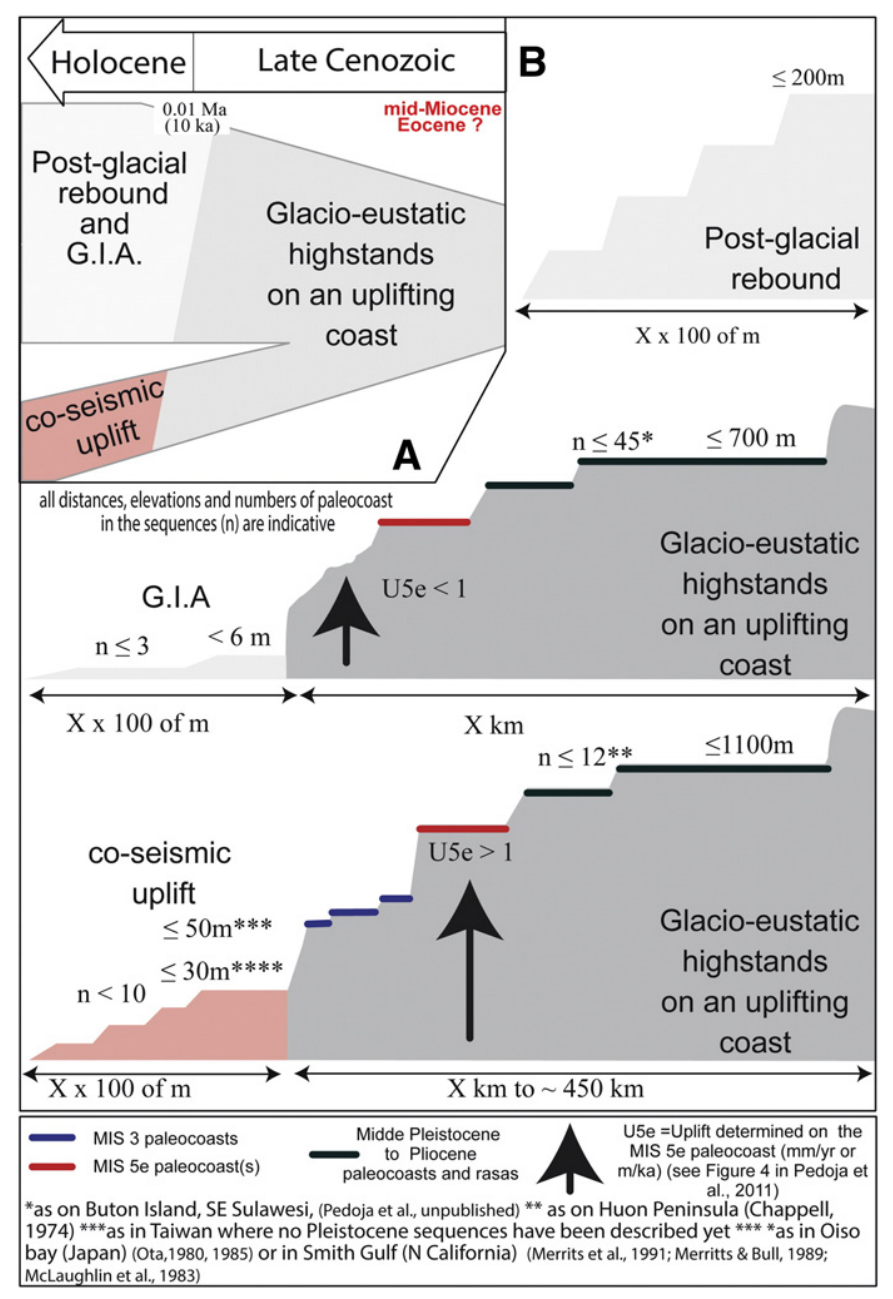

Fig. 1. Coastal tectonics revisited. A) Mode of formation of a Cenozoic sequence of paleoshorelines. B) Synthetic transects across composite sequences. For example, the Holocene sequence is co-seismic, whereas Pleistocene (and older) sequences correspond to the geomorphic record of interglacial highstands (stage and substage) on uplifting coastlines. All values come from our dataset (see Supplementary data). G.I.A. = Global Isostatic Adjustment. Note 1) that we exclude Holocene shorelines and strandlines due to major storm events, 2) for clarity we described shorelines associated with post-glacial rebound as Holocene, whereas their formation starts in the Late Pleistocene (after the last glacial maxima), 3) we separated coastal sequences due to post-glacial rebound (former glaciated coast) from G.I.A. but the first is just part of the latter concerning mechanics. Finally, note that such processes (co-seismic, G.I.A., glacio-eustatic highstand superimposed against a rising coastline are effective during each highstand (see text for more details).

estimates of past interglacial sea level from the isotopic record are typically $10 \mathrm{~m}$ (see for instance Siddal et al., 2006, for a review). In this study, we assume that the Middle Pleistocene to Holocene interglacials are polyphased, and spatially diachronic. We assume that the last four interglacials are polyphased under the following constraints: MIS 5 includes the three relative highstands MIS 5a ( $85 \pm 10 \mathrm{ka}), 5 \mathrm{c}(105 \pm$ $10 \mathrm{ka}$ ) and $5 \mathrm{e}$ (the latter highstand lasted from $128 \mathrm{ka}$ to $\sim 116 \mathrm{ka}$; e.g. Stirling et al., 1998) for which we use a composite age of $122+/-6$ ka; MIS 7 lasted from 230 to $190 \mathrm{ka}$ (i.e. $210 \pm 20 \mathrm{ka}$ ); MIS 9 lasted from 330 to $310 \mathrm{ka}$ (i.e. $320 \pm 10 \mathrm{ka}$ ); MIS 11 lasted from 420 to $380 \mathrm{ka}$ (i.e. $400 \pm 20 \mathrm{ka}$ ). Less frequent are shorelines correlated to MIS 3 that lasted from 24 to 59 ka (Martinson et al., 1987) though the interval is most often bracketed between $20 \mathrm{ka}$ and $60 \mathrm{ka}$.

Although Middle and Upper Pleistocene as well as Holocene shorelines (MIS 11 onwards) are well documented, little attention has been devoted to the upper parts of these sequences, in particular, with respect to the genesis of compound paleocoasts (as for example in
Keskin et al., 2011), rasas (see Guilcher, 1974; Pedoja et al., 2006a,b; Regard et al., 2010) and strandflats (Guilcher et al., 1986) (Fig. 2). Rasas can be defined as sequences of rocky paleocoasts wherein shoreline angles are not discernible (Guilcher, 1974; Pedoja et al., 2006a,b; Regard et al., 2010). Their formation was promoted before and during early Pleistocene times, during periods of faster oscillations and lower amplitudes in sea-level fluctuations than since the Middle Pleistocene. See examples from Spain described by Alvarez-Marrón et al. (2008) and western Scotland by Dawson et al. (2013). Strandflats are sequences of strandlines formed in glacial or periglacial environments (Guilcher et al., 1986; this study). Strandplains are due to multiple occupations during former sea levels, and are consistent with sedimentary cannibalization (e.g. beach ridges) (e.g. eastern USA, southern Australia, see above).

The relationships between coastal morphodynamics, sea-level fluctuations and tectonics may be deciphered from the vertical superposition of strandlines, the sequence whose geometry and shape (spacing between two successive strandlines, width of each level) chiefly reflect the succession of highstands (as "weak" vs "strong" interglacial stages and substages). The overall confluence of these factors is akin to a barcode, variably stretched by local tectonics, and sometimes refolded by non-uniform or low vertical ground motions as well as local faulting. That first-order pattern of the barcode is understood in principle but the details remain elusive (see Waelbroeck et al., 2002; Siddal et al., 2006; Rohling et al., 2009). This plexus of factors strikes a challenge to disentangle individual strandlines. Information on older sea-level histories is naturally even more speculative, in spite of the current knowledge of the global isotopic trend (e.g. Lisiecki and Raymo, 2005) (Fig. 3). The Cenozoic onset of the sea-level barcode remains an open question that we thereafter address.

The overlap in standards may be misleading. For example MIS 1 frequently is equated with the Holocene Series, although it is approximately $4 \mathrm{ka}$ longer than the Holocene and therefore includes part of the Upper Pleistocene. In this work, we conform to the version of the geological time scale edited by Gradstein et al. (2012) for the name and duration of Erathem, System, Series and Stages. A majority of studies on coastal sequences use the isotopic scale. In this study, we follow the timing and durations of Siddal et al. (2006).

\section{The database}

We base our analysis on an updated synthesis of sea-level change indicators for MIS 1, MIS 3, MIS 5e, MIS 11 and the ages of upper strandlines that belong to long-lasting sequences. We further subdivided the data in order to account for major geodynamic settings, including passive, transform and active margins, as well as hotspots.

Our database on Cenozoic sequences of paleoshorelines is expanded from Pedoja et al. (2011). More particularly, for the sequences where elevation of MIS 5e strandlines are known (now 935 sites based on 988 references), we added, when available, the elevation of MIS 1 (185 sites), MIS 3 ( $\sim 12$ sites), MIS 11 (31 sites) and age and elevation data for the uppermost strandline of the sequence. This entailed 135 "extrapolated" sites and 52 sites from the literature on Paleogene and Neogene shorelines. All these data were compiled in tables following the main geodynamic settings for each site, including the location, geography, and elevation of strandlines (see Supplementary data). Supplementary data are summarized in Table 1. Regarding coastal geography, we distinguished three kinds of uplifted coastal segments: 1) linear coastal segments subdivided into straight and en echelon portions, 2) concave and convex coastal segments (capes, bays, fjords, peninsula, caves) that form complex geographies (continuous or not with succession of capes and bays), and 3) circular coastal segments: islands and archipelagos.

Holocene and Late Pleistocene ( MIS 1) shorelines and more particularly those younger than $6 \mathrm{ka}$ (Mid-Holocene and onward) are the most frequently described (Pirazzoli, 1991). In this paper, we only 


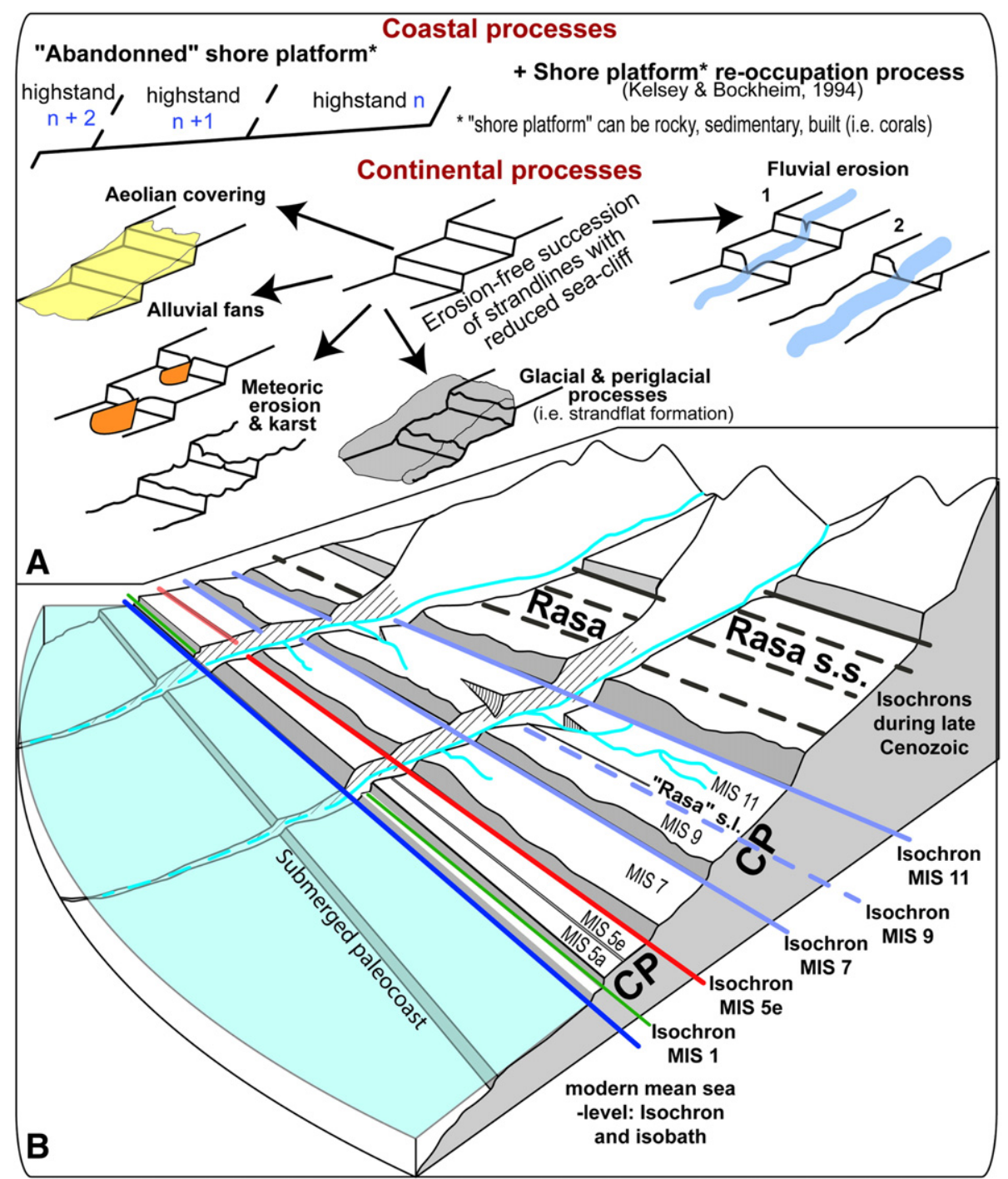

Fig. 2. Rasas, compound paleocoasts, strandflats and uplifted coastal plains. A) Processes involved in the formation of such morphologies, B) Morphology of rasas and compound coast. The vast majority of compound paleocoasts are frequently Middle and Upper Pleistocene in relative position (re-occupation of stage $5 \mathrm{e}$ by $5 \mathrm{a}$ for example), whereas the rasas (sensu stricto) are early Pleistocene or older in age.

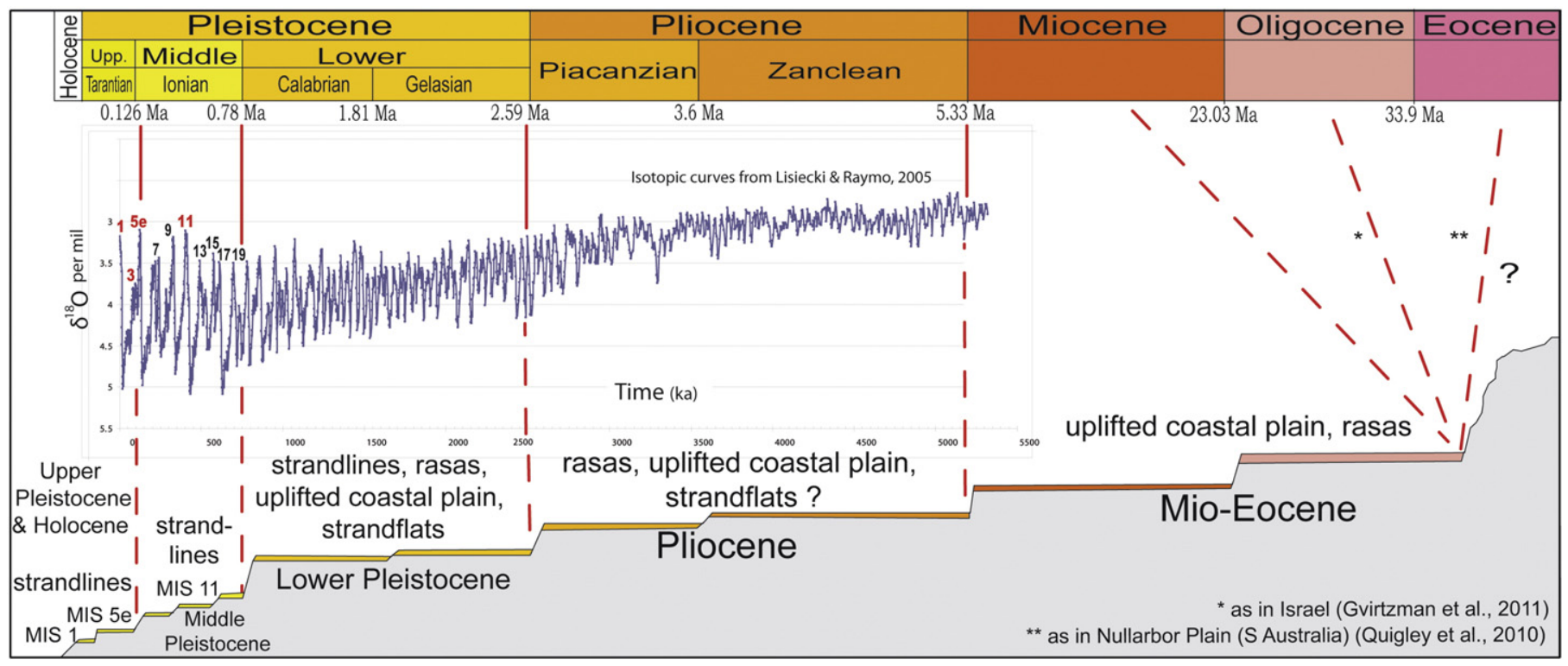

Fig. 3. Relationship between sea-level variation (as represented by isotopic curves) and geomorphic record on uplifting coasts. 
retain Holocene shorelines that are embedded in sequences including the MIS 5e coastal benchmark.

MIS 3 is considered an interstadial which corresponds to an intermediate climate state between full interglacial and glacial conditions. Sea level during this period was well below its current position and varied considerably from 40 to $80 \mathrm{~m}$ below modern sea level according to different estimates (e.g. Chappell, 1974; Chappell and Veeh, 1978; Chappell et al., 1996; Cabioch and Ayliffe, 2001; Yokoyama et al., 2001a,b,c; Waelbroeck et al., 2002; Siddal et al., 2006; Rohling et al., 2009). The number and ages of the sea-level highstands are still discussed but the high variability of sea-level fluctuations during this period is associated with catastrophic and episodic collapse of ice sheets in the North Atlantic region during Heinrich events (Siddal et al., 2006). Similarly to MIS 1, the poor constraints on sea level during MIS 3 led us to ignore uplift rates based on shoreline elevations for this interval of time.

Paleocoasts correlated with MIS 5e are extremely frequent. Conflicting hypotheses or disagreements on the elevation of MIS 5e shorelines are found in the literature at seven sites: Santa Cruz and Palos Verdes Hills (California, USA), Kubyshevski and Cape Van der Lind, respectively on Iturup and Urup islands (Kurils, Russia), Al Hoceima (Morocco), Valdivia (Chile) and Luwuk, north Sulawesi island (Indonesia). Details can be found in the Supplementary data.

During the last decades, strandlines and paleocoasts associated with MIS 11 have been the subject of two regional syntheses: in Japan (Masuda, 2007) and in Northern Chile (Ortlieb et al., 1996). More recently, a global synthesis was provided by Bowen (2010), wherein 11 sites with MIS 5e and MIS 11 strandlines are dated. We included all the sites provided by Bowen (2010) except two. Regarding the Sabatini site in Italy, we considered that the MIS 5e shorelines in the area (Pedoja et al., 2011) stand at $37 \pm 8 \mathrm{~m}$ whereas Bowen (2010) only considered a local shoreline angle at $20 \pm 1 \mathrm{~m}$. We chose to ignore the elevation measurements of the MIS 11 strandline in West Sussex, because the relationship between this terrace and the MIS 11 highstand was unclear (Bowen, 2010).

Our uplift rates (based on MIS 5e and MIS 11 benchmarks) reject any a priori eustatic correction (as in Pedoja et al., 2011), and therefore correspond to the actual, apparent uplift rates. We simply calculated $\mathrm{V}=\mathrm{E} / \mathrm{A}$ where $\mathrm{E}$ is the current elevation of the paleoshoreline relative to current local sea level and $\mathrm{A}$ is the age of the considered highstand (MIS 5e, 11). The resulting uplift rates can vary by as much as $50 \%$, depending on 1) the correction for eustasy, 2) the time-range considered for the sea level permanency, (i.e. duration of the highstands), and 3) the reference level for the elevation measurements: i.e. the local tidetime table or geoid 0 for differential GPS data or the "morphological" modern sea level. In other words, modern shoreline angles of rockyshore platforms are often above the geoid or the reference of the tidetime tables. See general discussions in Jardine (1981) or van de Plassche (1986). The source of uncertainty in our attempt to decipher past sea level is increasingly important when coastal indicators are recent (MIS 1, 3, 5e) and low-standing $(\sim<15 \mathrm{~m})$.

Overall, the literature dealing with descriptions of Neogene and Paleogene strandlines is scarce. Working on intertidal biotas through Phanerozoic times, Johnson and Baarli (2012) recorded 102 articles dealing with fossil shorelines for the Neogene (either rocky, muddy or sandy). In this study, out of 32 references we list 52 sites where shorelines dating back to the Pliocene (5.3 to 2.6 Ma) and even older (e.g. up to Eocene) have been described. Because of this lack of data, we extrapolated a minimum age of onset for the sequence at 527 sites (based on MIS 5e uplift rates). We then retained only Lower Pleistocene and older sites (135 sites) to better decipher the onset of formation of coastal sequences. This calculation crudely assumes that a constant uplift rate prevailed throughout, which is not necessarily the case (e.g. Saillard et al., 2009). It is also assumed that the uppermost fingerprint of the sequence formed during a sea-level highstand similar to MIS5e. Therefore, these estimates are regarded as indicative speculations and by no means as facts.
Our work is mainly based on the compilation of previous works and we recognize that our database is not exhaustive and that we may have made incorrect assumptions regarding some sites. If our readers find any unwarranted errors in these data, we will appreciate learning about them. Our findings are provisional as they depend on published sources of variable quality. Consequently ours conclusions need to be bolstered by chronometric, geophysical, seismic and geodetic data.

\section{Sequences of strandlines through space and time}

\subsection{State of the art}

Sequences of Cenozoic shorelines stacked by sea-level oscillations and tectonic uplift are common features worldwide (Pedoja et al., 2011). This occurs regardless of the geodynamic settings, but not identically (see below). The correlation between modern coastal geomorphology and tectonic settings on both global and regional scales was established more than 40 years ago (Inman and Nordstrom, 1971). Most striking are the coastlines along passive continental margins and the rugged coastlines along convergent plate boundaries. Coastlines on passive continental margins typically exhibit broad coastal plains bordered offshore by wide continental shelves and gentle continental slopes. Such coastlines, and therefore strandlines, are chiefly depositional and shaped by broad sandy beaches and offshore barriers and/or broad coral reefs at low latitudes (see Supplementary data). In contrast, coastlines near active continental margins generally consist of coastal hills or mountains bordered offshore by narrow continental shelves and deep subduction trenches. These active margins are characterized by rugged erosional landforms such as steep sea cliffs and rocky headlands, islands and sea-stacks (e.g. Inman and Nordstrom, 1971; Lajoie, 1986). This general law of physical geography applies to many coasts (i.e. eastern vs. western coasts of North America), but is not inviolate. For instance, the coasts of Western Europe (i.e. Portugal, Spain, France, and England) are more rocky than predicted (Johnson and Libbey, 1997).

At a global scale, another counterintuitive result is that geographically extended and long-lasting (in terms of age) coastal sequences are present mainly in areas where apparent uplift rates are very low to moderate (Pedoja et al., 2011; this study). We infer that results from the tradeoff between uplift rates and the construction/abrasion capacity, that increases under low uplift rates as the relative sea level remains stationary long enough during the formation of a strandline, and offsets the destruction capacity of erosion once emerged. As suggested by the results of our compilation, the maximum number of strandlines in a sequence is seemingly independent of uplift rates. To our knowledge, the most developed continuous sequences include those from southern Australia, central Indonesia, and southern Peru. Late Cenozoic sequences from southern Australia (Sandiford, 2007) record up to 150 shorelines on a slowly uplifting passive margin setting $(0.06 \pm 0.01 \mathrm{~mm} / \mathrm{yr}$ for MIS 5e at Cape Nelson/Warrnambool; see Supplementary data) related to sea-level fluctuations dating as far back as the Miocene. Extensive Plio-Quaternary strandlines (45 successive coral reef terraces) are located in SE Sulawesi, Indonesia, where uplift rates do not exceed $0.5 \mathrm{~mm} / \mathrm{yr}$ (Pedoja et al., unpublished). Likewise, Chala bay in Peru is imprinted by a sequence of 27 marine terraces (e.g. Gabert et al., 1970; Goy et al., 1992; Zazo, 1999; Regard et al., 2010) with an uplift rate of $0.54 \pm 0.03 \mathrm{~mm} / \mathrm{yr}$. On the other hand, fast uplifting areas do not necessarily include many levels. Only 5 first-order Pleistocene marine terraces are found on the Kamchastky Peninsula, where coastal uplift rates are higher than $2 \mathrm{~mm} / \mathrm{yr}$ (Pedoja et al., 2013a). Overall, long-lasting sequences from the Neogene (locally Paleogene) are preferentially found in regions of low to moderate coastal uplift such as passive margins (e.g. South Africa, northwestern Spain, Brittany, Argentina), hotspot chains (e.g. Lanzarote, in the Canary Islands) or transform boundaries (Gvirtzman et al., 2011). 
Table 1

Coastal uplift rates as a function of the geodynamic setting. Given values are apparent uplift rates, because we did not account for any a priori eustatic change in sea level. The average values that are provided are only indicative of trends, because they equally weight all areas regardless of spatial extent or data density.

\begin{tabular}{|c|c|c|c|c|c|c|c|c|c|c|c|c|c|c|}
\hline \multirow[b]{2}{*}{ Case } & \multirow[b]{2}{*}{ Domain } & \multirow{2}{*}{$\begin{array}{c}\text { (based } \\
n^{\circ} \\
\text { on MIS } \\
5 \mathrm{e} \text { ) }\end{array}$} & \multicolumn{2}{|c|}{ MIS 1} & \multicolumn{4}{|c|}{ MIS 5e } & \multicolumn{4}{|c|}{ MIS 11} & \multicolumn{2}{|c|}{ "Old shorelines" } \\
\hline & & & E & $\mathrm{MoE}$ & E & MoE & Uplift & Moe & $\mathrm{E}$ & MoE & Uplift & Moe & Age & "Method" \\
\hline & ND & 31 & 5.53 & 1.25 & 25.56 & 2.38 & 0.21 & 0.02 & $*$ & * & * & * & $\begin{array}{c}\text { Early } \\
\text { pleistocene }\end{array}$ & Extrapolated \\
\hline
\end{tabular}

\begin{tabular}{|c|c|c|c|c|c|c|c|c|c|c|c|c|c|c|}
\hline \multirow{2}{*}{$\mathrm{H}$} & Lord Howe & 1 & 1.50 & 1.00 & 4.00 & 1.00 & 0.03 & 0.01 & $*$ & $*$ & $*$ & $*$ & $*$ & $*$ \\
\hline & $\begin{array}{l}\text { Gambier - } \\
\text { Society }\end{array}$ & 6 & 1.35 & 0.10 & 6.83 & 1.75 & 0.06 & 0.01 & $*$ & $*$ & $*$ & $*$ & * & $*$ \\
\hline \multirow{2}{*}{ o } & Trinidad & 2 & * & $*$ & 17.50 & 1.00 & 0.14 & 0.01 & * & $*$ & * & * & * & * \\
\hline & Reunion & 2 & $*$ & * & 5.00 & 1.00 & 0.04 & 0.01 & * & $*$ & $*$ & $*$ & * & $*$ \\
\hline $\mathrm{t}$ & $\begin{array}{l}\text { Santa } \\
\text { Elena }\end{array}$ & 1 & 3.00 & 1.00 & 9.00 & 1.00 & 0.07 & 0.01 & * & $*$ & $*$ & $*$ & Zanclean & Dated \\
\hline S & $\begin{array}{l}\text { Cocos- } \\
\text { Keeling }\end{array}$ & 2 & 0.50 & 0.10 & -2.50 & 1.50 & -0.02 & -0.01 & $*$ & $*$ & $*$ & $*$ & * & $*$ \\
\hline $\mathrm{p}$ & $\begin{array}{l}\text { Chagos - } \\
\text { Maldives }\end{array}$ & 5 & $*$ & $*$ & -16.00 & 2.50 & -0.13 & -0.02 & $*$ & $*$ & $*$ & $*$ & * & $*$ \\
\hline 0 & $\begin{array}{l}\text { Samoa - } \\
\text { Caroline }\end{array}$ & 2 & $*$ & * & -9.50 & 5.25 & -0.08 & 0.04 & * & $*$ & $*$ & $*$ & * & $*$ \\
\hline $\mathrm{t}$ & $\begin{array}{l}\text { Cape } \\
\text { Verde }\end{array}$ & 1 & $*$ & * & 2.50 & 1.00 & 0.02 & 0.01 & * & $*$ & $*$ & $*$ & Piacenzian & Extrapolated \\
\hline C & Hawaii & 10 & $*$ & * & -3.20 & 2.75 & -0.03 & 0.01 & * & $*$ & $*$ & $*$ & $\begin{array}{c}\text { Early } \\
\text { pleistocene }\end{array}$ & Extrapolated \\
\hline h & Daitao & 2 & * & * & 9.50 & 1.00 & 0.08 & 0.01 & $*$ & $*$ & $*$ & $*$ & $*$ & $*$ \\
\hline \multirow[t]{4}{*}{$\mathrm{i}$} & Canary & 4 & $*$ & $*$ & 4.20 & 0.40 & 0.03 & 0.00 & 35.00 & 1.00 & 0.09 & 0.01 & $\begin{array}{c}\text { Miocene, } \\
\text { zanclean, } \\
\text { piacenzian }\end{array}$ & Dated \\
\hline & Bermuda & 2 & $*$ & * & 4.00 & 1.00 & 0.03 & 0.01 & 21.00 & 1.00 & 0.05 & 0.00 & $*$ & $*$ \\
\hline & Cook & 8 & 1.70 & 1.00 & 0.53 & 2.98 & 0.00 & 0.01 & * & $*$ & $*$ & $*$ & * & $*$ \\
\hline & Azores & 3 & $*$ & * & 17.67 & 2.33 & 0.14 & 0.02 & $*$ & $*$ & $*$ & * & $*$ & $*$ \\
\hline \multicolumn{2}{|c|}{ Sum/mean } & 51 & 1.61 & 0.64 & 1.30 & 2.11 & 0.01 & 0.01 & 26.75 & 1.00 & 0.07 & 0.01 & Mean on th & of site \\
\hline
\end{tabular}

\begin{tabular}{|c|c|c|c|c|c|c|c|c|c|c|c|c|c|c|}
\hline \multirow[b]{2}{*}{$\mathrm{P}$} & $\begin{array}{l}\text { Africa } \\
\text { West \& South }\end{array}$ & 33 & 3.50 & 0.91 & 6.41 & 1.13 & 0.05 & 0.01 & * & * & * & * & Zanclean & Dated \\
\hline & Africa East & 16 & 3.17 & 0.50 & 6.55 & 1.06 & 0.05 & 0.01 & * & * & * & * & $\begin{array}{c}\text { Early } \\
\text { pleistocene }\end{array}$ & Extrapolated \\
\hline S & $\begin{array}{l}\text { East South } \\
\text { America }\end{array}$ & 33 & 6.33 & 1.19 & 13.06 & 1.73 & 0.11 & 0.01 & 49.50 & 4.00 & 0.12 & 0.010 & Piacenzian & Dated \\
\hline $\mathrm{S}$ & Australia & 23 & 2.00 & 1.00 & 7.66 & 1.10 & 0.06 & 0.01 & 26.00 & 1.00 & 0.07 & 0.004 & $\begin{array}{l}\text { Eocene, } \\
\text { miocene, } \\
\text { pliocene }\end{array}$ & Dated \\
\hline V & $\begin{array}{l}\text { East North } \\
\text { America }\end{array}$ & 22 & * & * & 6.48 & 1.16 & 0.05 & 0.01 & 15.00 & 1.00 & 0.04 & 0.003 & $\begin{array}{l}\text { Miocene, } \\
\text { pliocene? }\end{array}$ & Dated \\
\hline & $\begin{array}{l}\text { Asia } \\
\text { mainland }\end{array}$ & 17 & 4.70 & 1.10 & 14.44 & 2.32 & 0.12 & 0.02 & * & * & * & * & Piacenzian & Extrapolated \\
\hline $\mathrm{m}$ & $\begin{array}{l}\text { New } \\
\text { Caledonia }\end{array}$ & 16 & $*$ & $*$ & -2.28 & 1.09 & -0.02 & 0.01 & * & * & * & * & Piacenzian & Dated \\
\hline $\mathrm{r}$ & $\begin{array}{l}\text { West } \\
\text { Europe }\end{array}$ & 90 & * & $*$ & 6.80 & 2.00 & 0.06 & 0.02 & 31.00 & 1.00 & 0.08 & 0.005 & $\begin{array}{l}\text { Miocene, } \\
\text { Pliocene }\end{array}$ & Dated \\
\hline & $\begin{array}{l}\text { North } \\
\text { Mediterranean }\end{array}$ & 67 & $*$ & $*$ & 3.87 & 1.90 & 0.03 & 0.01 & 43.33 & 1.00 & 0.11 & 0.01 & Piacenzian & Dated \\
\hline
\end{tabular}


Table 1 (continued)

\begin{tabular}{|c|c|c|c|c|c|c|c|c|c|c|c|c|c|c|}
\hline \multirow{2}{*}{ Case } & \multirow{2}{*}{ Domain } & \multirow{2}{*}{\begin{tabular}{|c} 
(based \\
$n^{\circ}$ \\
on MIS \\
$5 \mathrm{e}$ ) \\
\end{tabular}} & \multicolumn{2}{|c|}{ MIS 1} & \multicolumn{4}{|c|}{ MIS 5e } & \multicolumn{4}{|c|}{ MIS 11} & \multicolumn{2}{|c|}{ "Old shorelines" } \\
\hline & & & E & $\mathrm{MoE}$ & E & $\mathrm{MoE}$ & Uplift & Moe & E & MoE & Uplift & Moe & Age & "Method" \\
\hline \multirow{5}{*}{$\begin{array}{l}\mathrm{g} \\
\mathrm{i} \\
\mathrm{n}\end{array}$} & India & 6 & 4.25 & 0.75 & 6.03 & 1.08 & 0.05 & 0.01 & $*$ & $*$ & $*$ & $*$ & $*$ & $*$ \\
\hline & Svalbard & 1 & 37.00 & 1.00 & 15.00 & 2.50 & 0.12 & 0.02 & $*$ & $*$ & $*$ & $*$ & $*$ & $*$ \\
\hline & Arabia & 5 & 2.00 & 1.25 & 7.40 & 2.00 & 0.06 & 0.02 & * & $*$ & $*$ & * & $\begin{array}{c}\text { Early } \\
\text { pleistocene }\end{array}$ & Extrapolated \\
\hline & Alaska & 7 & * & $*$ & 8.61 & 1.64 & 0.07 & 0.01 & 23.00 & 1.00 & 0.06 & 0.004 & * & * \\
\hline & Antarctica & 1 & $*$ & $*$ & 26.00 & 5.00 & 0.21 & 0.04 & $*$ & * & * & * & * & * \\
\hline \multicolumn{2}{|c|}{ Sum/mean } & 337 & 5.34 & 1.04 & 6.88 & 1.67 & 0.06 & 0.01 & 36.00 & 1.67 & 0.09 & 0.01 & \multicolumn{2}{|c|}{ Mean on the total $n^{\circ}$ of site } \\
\hline
\end{tabular}

\begin{tabular}{|c|l|l|l|l|l|l|l|l|l|l|l|l|l|l|l|l}
\hline $\begin{array}{l}\mathrm{R} \\
\mathrm{i}\end{array}$ & $\begin{array}{l}\text { Baja } \\
\mathrm{f}\end{array}$ & 27 & $*$ & $*$ & 15.39 & 1.24 & 0.13 & 0.01 & $*$ & $*$ & $*$ & $*$ & Piacenzian \\
\cline { 2 - 10 } & Red Sea & 29 & 0 & 1 & 11.70 & 1.14 & 0.10 & 0.01 & 30.00 & 5.00 & 0.08 & 0.01 & $*$ \\
\hline
\end{tabular}

\begin{tabular}{|c|c|c|c|c|c|c|c|c|c|c|c|c|c|c|}
\hline $\mathrm{T}$ & $\begin{array}{l}\text { Peninsula } \\
\text { Antarctica }\end{array}$ & 4 & 17.00 & 1.00 & 47.50 & 6.50 & 0.39 & 0.06 & * & * & * & * & $*$ & $*$ \\
\hline r & Caribbean & 23 & 3.25 & 0.75 & 10.06 & 1.78 & 0.08 & 0.01 & 24.50 & 4.50 & 0.06 & 0.01 & $\begin{array}{c}\text { Early } \\
\text { pleistocene }\end{array}$ & Extrapolated \\
\hline a & East Medit. & 26 & 2.37 & 1.00 & 10.62 & 1.53 & 0.09 & 0.01 & 49.00 & 3.00 & 0.12 & 0.01 & $\begin{array}{c}\text { Miocene, } \\
\text { pliocene }\end{array}$ & Dated \\
\hline s & Anatolia & 5 & 3.00 & 1.00 & 17.60 & 1.70 & 0.14 & 0.02 & 73.00 & 5.20 & 0.18 & 0.02 & $\begin{array}{c}\text { Early } \\
\text { pleistocene }\end{array}$ & Extrapolated \\
\hline 0 & NW Sicily & 12 & * & * & 13.67 & 2.50 & 0.11 & 0.02 & * & * & * & * & Piacenzian & Extrapolated \\
\hline r & $\begin{array}{l}\text { South New } \\
\text { Zealand* }\end{array}$ & $10^{*}$ & 3.50 & 1.00 & 58.15 & 3.15 & 0.48 & 0.04 & * & * & * & * & Piacenzian & Extrapolated \\
\hline & Californias & 41 & $30^{* *}$ & 1.00 & 51.63 & 3.19 & 0.42 & 0.04 & 121.67 & 8.33 & 0.30 & 0.03 & Zanclean & Extrapolated \\
\hline \multicolumn{2}{|c|}{ Sum/mean } & 121 & 6.66 & 0.96 & 30.50 & 2.55 & 0.25 & 0.02 & 76.13 & 5.93 & 0.19 & 0.02 & \multicolumn{2}{|c|}{ Mean on the total $n^{\circ}$ of site } \\
\hline
\end{tabular}

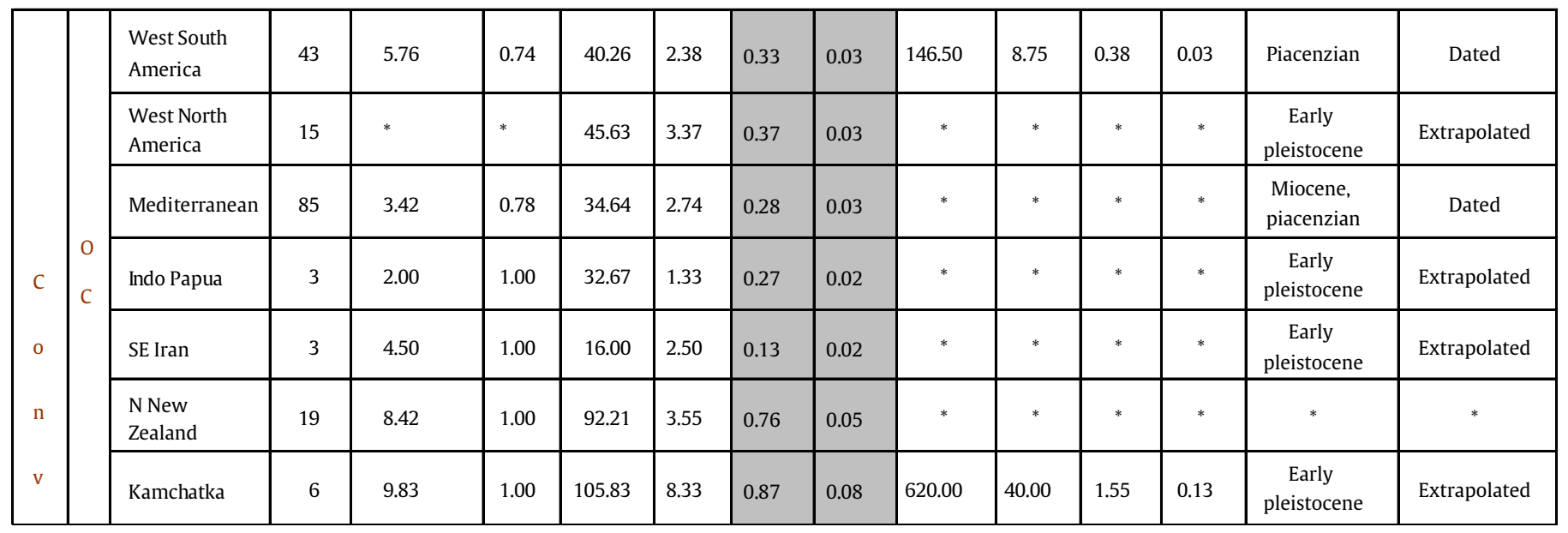


Table 1 (continued)

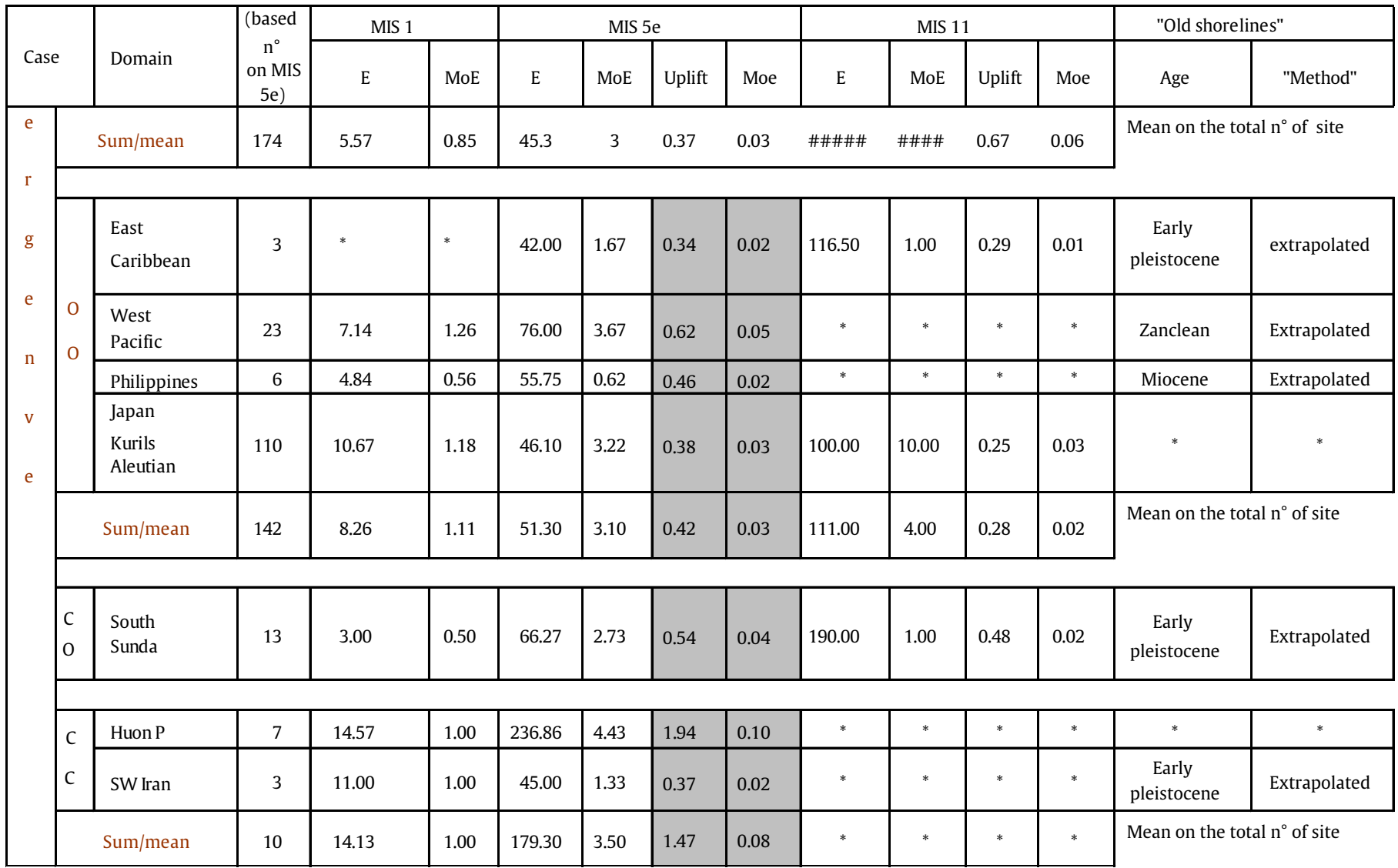

*Site Franz Joseph excluded from mean.

${ }^{* *}$ Only one site (Smith Gulf) with holocene co-seismic shorelines.

Geographically continuous sequences over long coastal stretches are found principally on passive margins like the Atlantic coasts of South America (Fig. 4A). Along this coasts, sequences are disrupted only by fluvial systems. This observation holds at the continental scale but also at a local scale: fluvial destruction and/or tapping in coastal embayments. Along active margins, segmentation delimits blocks with distinct

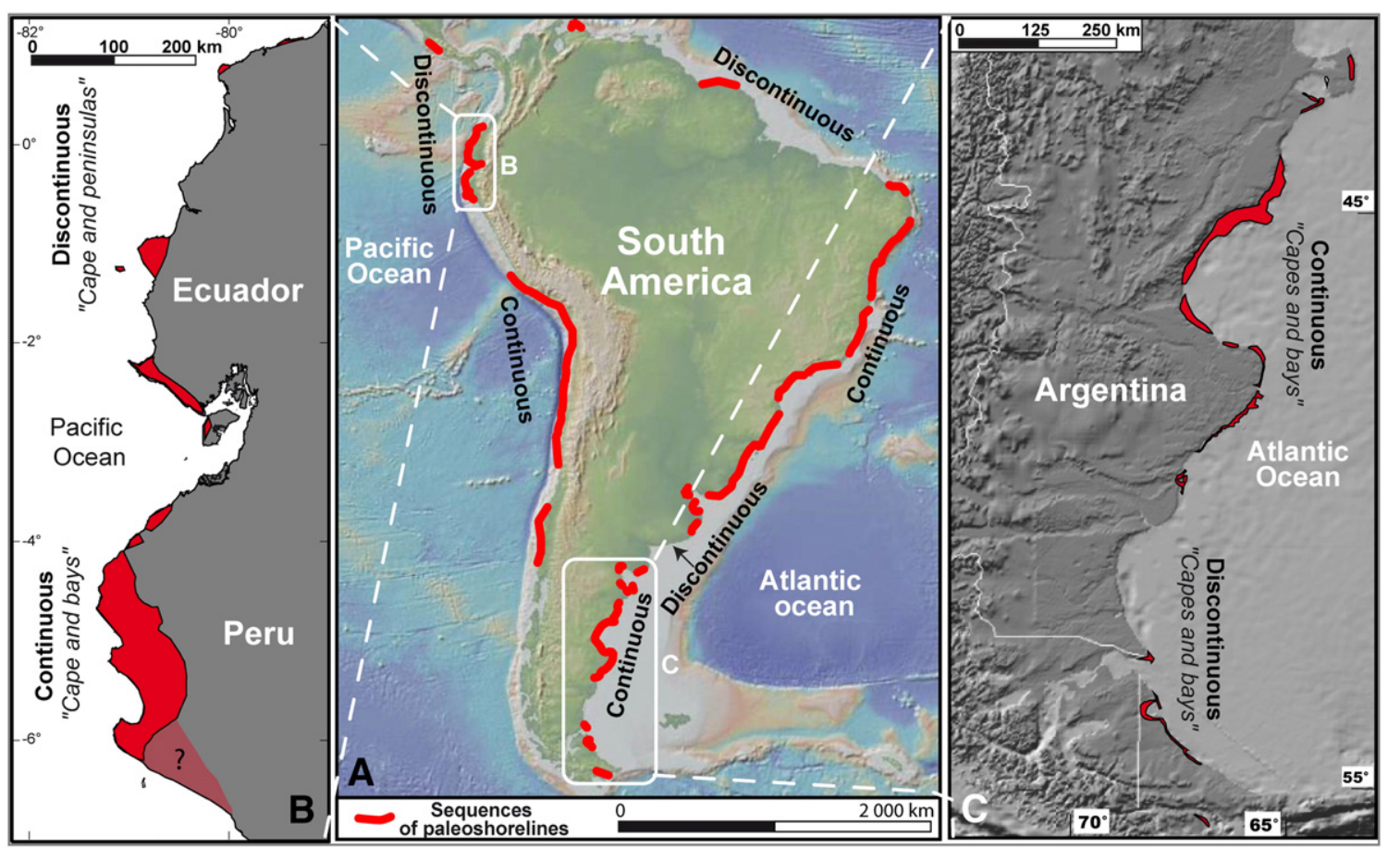

Fig. 4. Continental and regional repartition of Cenozoic coastal sequences. A) South America, B) Active margin, Nazca subduction, Ecuador and northern Peru, C) Passive margin, Argentina. 
tectonic behaviors. Some blocks lack emerged coastal sequences, possibly due to subsidence or stability. Consequently, the uplifted coastal segments are less continuous than in less active coastal areas. A good example to illustrate differences in the geographical partition of sequences is demonstrated by the coastal sequences of South America (Fig. 4A). This profound contrast was identified through the pioneering work of Darwin (1846), who described an asymmetry in their nature and partition between the east (mainly Brazil and Argentina) and the west (Ecuador, Peru, Chile). The Plio-Quaternary sequences of paleocoasts in South America, as characterized also by modern shorelines, are 1) predominantly rocky, though disrupted by sedimentary systems to the West (Pacific side) and 2) predominantly sedimentary, disrupted by rocky shores to the East (Atlantic margin). To the East, the coastal sequences are extensively well developed and present along very long continuous coastal stretches. Sequences in Brazil are described along more than $3000 \mathrm{~km}$ of coast, and the coastal stretch in eastern Patagonia (Argentina) is covered by $2000-\mathrm{km}$-long coastal sequences. In turn, along the western coasts of South America, preserved coastal sequences are more discontinuous (e.g. described sequences are lacking in central Peru between $7^{\circ} \mathrm{S}$ and $\left.15^{\circ} \mathrm{S}\right)$.

\subsection{Geographical distribution}

At a global scale, most coastlines are bordered by coastal sequences with the exception of large rivers mouths (Pedoja et al., 2011). At least $30000 \mathrm{~km}$ of worldwide coastlines are covered by emerged coastal sequences that can include tens of stacked paleoshorelines.

At a smaller continental scale, coastal segments covered by sequences of strandlines either are continuous, discontinuous or lacking
(Fig. 4A). Closer inspection (i.e. at a regional scale) shows that in some cases, the spacing of paleocoastal sequences may be enhanced on capes or peninsulas (Fig. 4B) though not systematically (capes and bays on Fig. 4C).

About $70 \%$ of the coastal sequences are located on concave and convex segments.

Among these, 33\% correspond to sequences located on headlands, points and peninsulas, and $14 \%$ on embayments, bays or fjords (Fig. 5). Sequences of strandlines located on linear segments of coastlines are less frequent (12\%, Fig. 6), while insular sequences amount to $18 \%$ (Fig. 7). A common paleogeographic evolution corresponds to the emergence of an island, followed by its connection to the adjacent mainland (either a continent or another island in the case of an archipelago (Fig. 8)) as evidenced for longer periods of time (Martin et al., 2003).

4.3. The lower part of the sequences, Holocene to Middle Pleistocene, MIS 1 to MIS 19

For this time range $(0-781 \mathrm{ka})$ covering the Holocene as well as the Ionian (Middle Pleistocene) and the Tarantian (Late Pleistocene) stages, we focused on the MIS 1, MIS 3, MIS 5e and MIS 11 highstands preserved as paleocoasts and discuss their conditions for preservation and apparent uplift rates.

\subsubsection{MIS 1 and MIS 3}

We identified 185 sites where elevations of the highest Holocene and MIS 5e paleoshorelines are known (Fig. 9 and Table 1). These sites are present in all kinds of geodynamic settings. The elevation of the

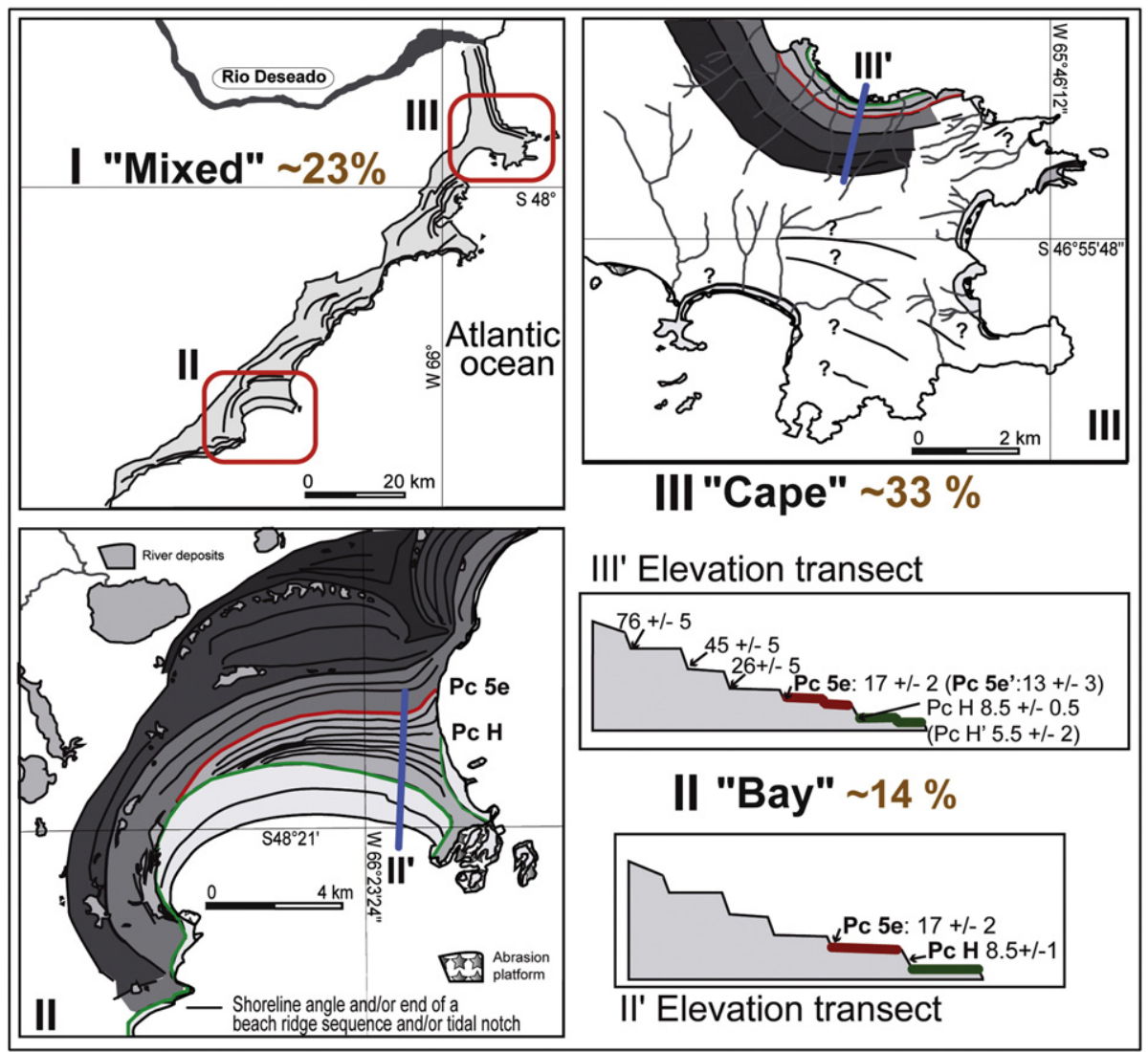

Fig. 5. Convex and concave segments ( 70\% dataset) I) "Mixed": example of a regionally continuous uplifted coastal segment with capes and bays or fjords (23\% dataset) from the southern part of the Deseado Peninsula, Eastern Patagonia (Pedoja et al., 2011b), II) example of a locally continuous uplifted coastal segment along a bay ( 14\% dataset)from Bahia Laura, Eastern Patagonia (Pedoja et al., 2011b), and III) example of a locally continuous uplifted coastal segment on a cape or point ( $33 \%$ dataset)from Punta Guanaco, Eastern Patagonia (Pedoja et al., 2011b). Note that in order to express the problem we faced while trying to geographically define the coastal sequences, we present a mixed coastal stretch (Argentina) from which we "extract" one peninsula and one bay. The size of observation informs the classification. 


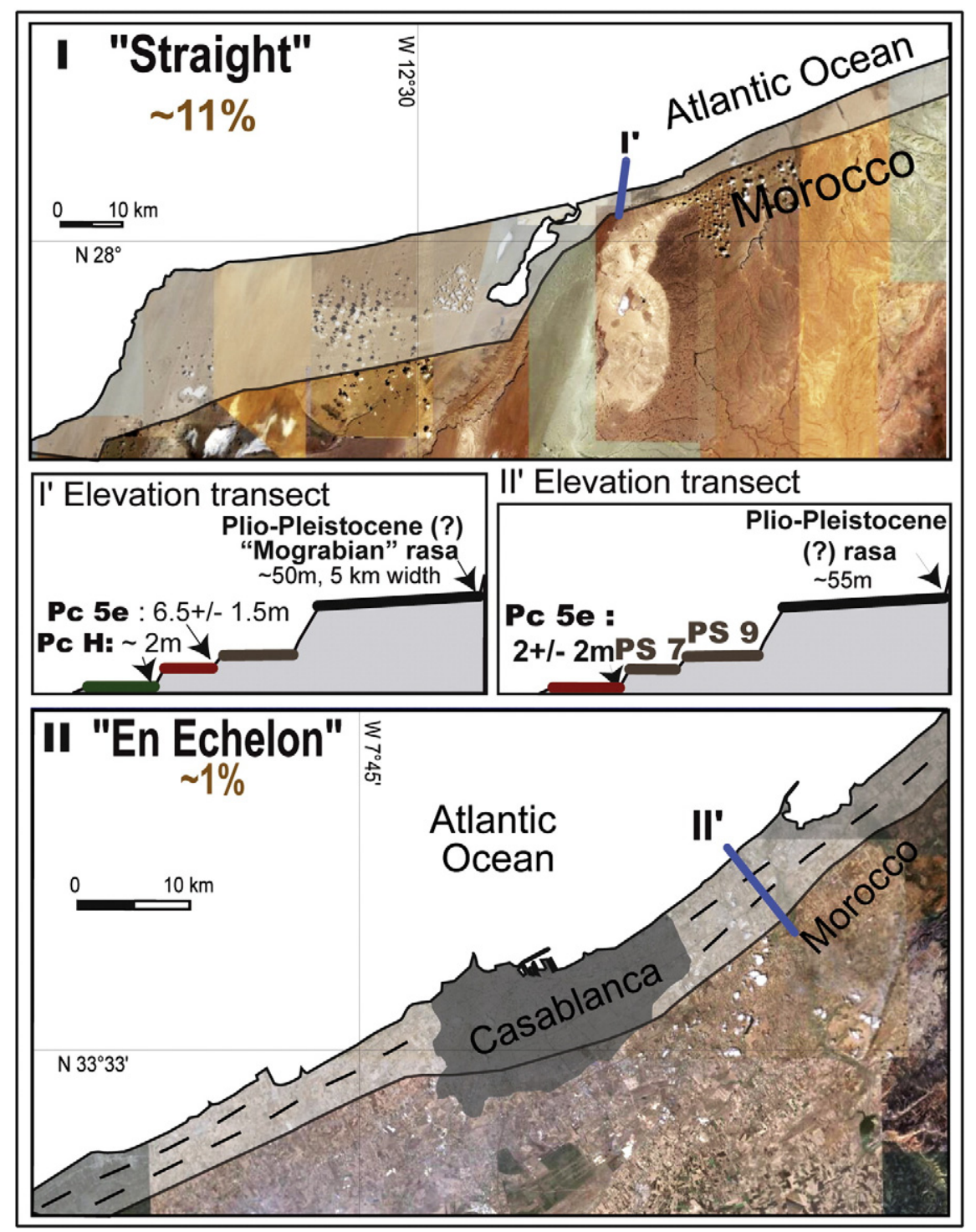

Fig. 6. Linear segments ( 12\% dataset) I) Example of a straight coastal segment (11\% dataset) from Tarfaya, Southern Morocco (Ortlieb, 1975; Brebion and Ortlieb, 1976; Hoang et al., 1978), II) Example of En echelon coast from Casablanca, Morocco (Coque and Jauzein, 1965; Texier et al., 1994; Lefèvre and Raynal, 2002; Occhietti et al., 2002; Texier et al., 2002; Chabli et al., 2005; Rhodes et al., 2006). Pc: paleocoast. Pc H: paleocoast correlated to MIS 1 (Holocene); Pc 5e: paleocoast correlated to MIS 5e.

Holocene sequences ranges from $0 \pm 1 \mathrm{~m}$ to $37 \pm 1 \mathrm{~m}$ (Svaalbard) with a mean of $6.3 \pm 1 \mathrm{~m}$. Most emergent Holocene strandlines (depositional, erosional or constructional) conform to their Pleistocene counterparts but are typically smaller, less marked, and better preserved (e.g. Lajoie, 1986; van de Plassche, 1986; Pirazzoli, 1994). Such morphological differences allow for a first-order distinction between Holocene and Pleistocene coastal sequences (see Pedoja et al., 2013a for a regional example).

Except at high latitudes where post-glacial rebound is extremely fast (Fig. 9), all sites (28) where the elevation of the highest shoreline is equal or higher than $12 \mathrm{~m}$ are located at very active margins where co-seismic episode raises Holocene sequences by a few tens of centimeters to a few meters (e.g. Pirazzoli, 1994). Holocene staircase sequences can include up to ten strandlines and the mean elevation of the highest shoreline angle is at $16+/ 1 \mathrm{~m}$, although maximum elevation locally reaches as much as 30-40 m (e.g. Smith Gulf, USA or Kamchastky peninsula, Russia).

MIS 3 paleocoasts are frequently inferred and discussed in the literature, for example in Algeria (Maouche et al., 2011, 2013; Pedoja et al., 2013b) or Eastern Turkey (Bekaroglu, 2012; Dogan et al., 2012a,b).
Sometimes MIS 3 paleocoasts are described independently from the MIS 5e benchmark (e.g. Isla Santa Maria, Chile, Melnick et al., 2006; Burica peninsula, Costa Rica, Morell et al., 2011). MIS 3 paleocoasts also are most likely to be well represented on coasts where post-glacial rebound is fast (e.g. Billefjorden and Svalbard, Alexanderson et al., 2011), although relative sea level during interstadials is particularly difficult to predict a priori. Yet, identifications of MIS 3 paleocoasts often remain ambiguous. Out of all purported MIS 3 sites, highstands remain only from fast uplifting coastlines, as found on the Mahia Peninsula in New Zealand (Berryman, 1992, 1993a,b), or islands of the Vanuatu archipelago such as Santo (Jouannic et al., 1980; Taylor et al., 1980; Jouannic et al., 1982; Taylor et al., 1982, 1987; Galipaud and Pineda, 1998), Malekula (Cabioch and Ayliffe, 2001) and Torres (Taylor et al., 1985), and Kikai island in the Ryukyus archipelago (Konishi et al., 1970; Ikeya and Ohmura, 1983; Ikeda et al., 1991; Ota and Omura, 1992; Sasaki et al., 2004; Maejima et al., 2005; Inagaki and Omura, 2006).

The first recognized paleocoasts formed during the MIS 3 highstands are coral reef terraces from the Huon Peninsula dated between $~ 30$ and $\sim 60$ ka (Bloom et al., 1974; Chappell, 1974). In Kanzarua (Fig. 10), the MIS 3 sequence was described as constituted by four terraces situated 


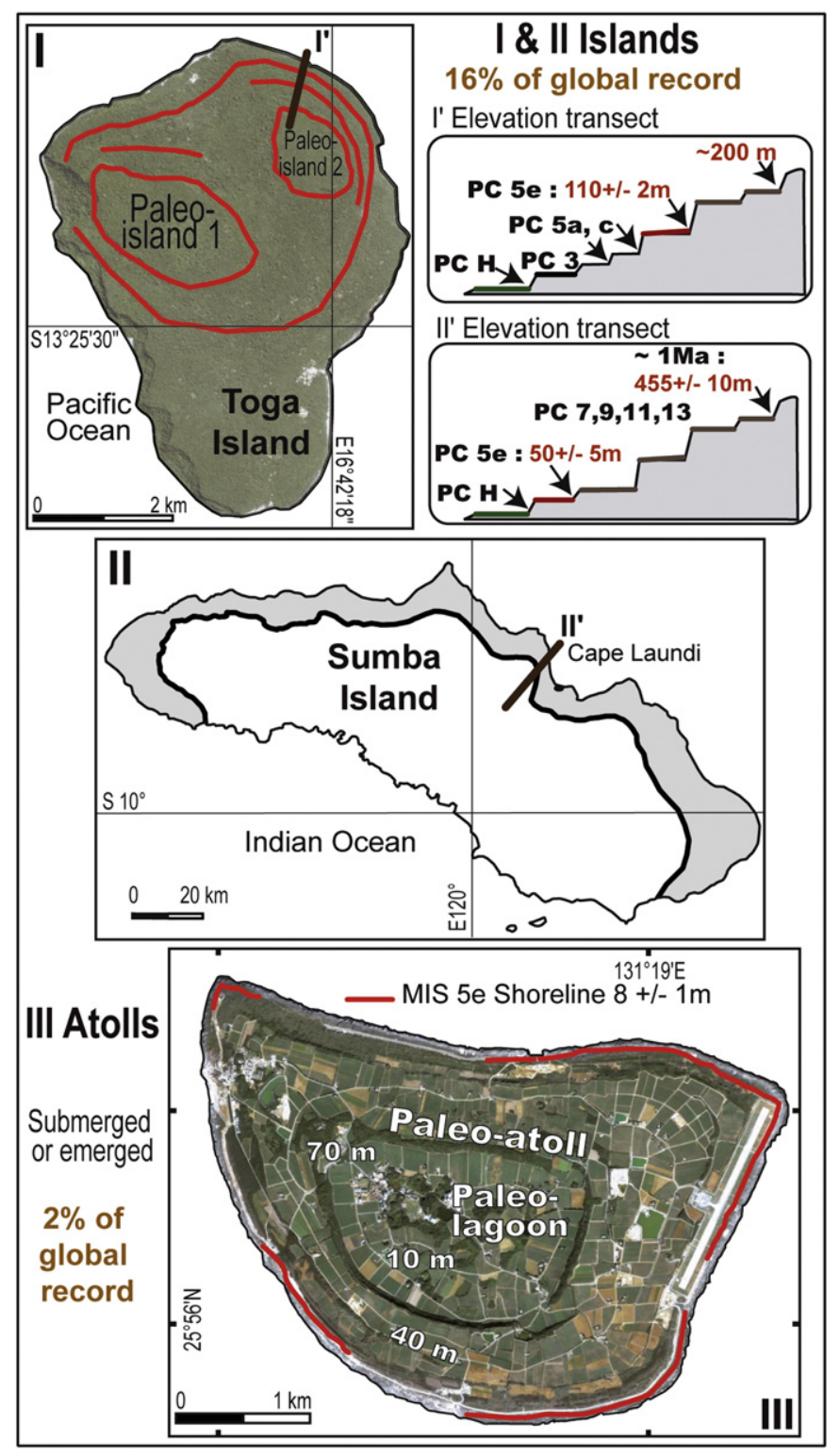

Fig. 7. Islands and atolls ( $18 \%$ dataset), I) Entire circumference of the island from Toga island (Torres Islands, Vanuatu, after Taylor et al., 1985) and II) coastal segment from Sumba island (Indonesia, after Hantoro, 1992; Pirazzoli et al., 1993). (16\% dataset), III) Atolls, (2\% dataset). Atolls can be re-emerged ex Kita Daito, Daito Islands Japan (Ota and Omura, 1992) or submerged, ex South Malé (Maldives), Diego Garcia (Chagos archipelago) (Woodroffe, 2005) Pc: paleocoast. Pc H: paleocoast correlated to MIS 1 (Holocene); Pc 5e: paleocoast correlated to MIS 5e;

at elevations of $\sim 30,60,90$, and $125 \mathrm{~m}$ and which were dated (U/Th on coral) as $31 \mathrm{ka}, 40 \mathrm{ka}, 51 \mathrm{ka}$ and $60 \mathrm{ka}$ (see margin of errors from Aharon and Chappel, 1986 on Figure 7B). The late Quaternary sea levels defined by coral terraces on the Huon Peninsula have been reconciled with deep-sea oxygen isotopes (Chappell et al., 1996), which rectified the misleading interpretation. More recent studies in the area (Yokoyama et al., 2001; Chappell, 2002) describe a MIS 3 sequence including at least 6 major terraces reaching $140 \mathrm{~m}$ in altitude and spanning a period from 60 to $38 \mathrm{ka}$. But, indeed, the early chronostratigraphy established at the Huon peninsula was used to interpret other records where the dating of coastal indicators led to the identification of strandlines related to MIS 3.

In terms of morphologies, the MIS 3 interstadial sea levels resulted in the formation of reduced (reefal or marine) terraces. Except in New Zealand, these are reefal terraces. In general, they overlook a Holocene coastal sequence of co-seismic origin (HS on Fig. 10), and are dominated by high-standing ( $>150 \mathrm{~m}$ ) Upper Pleistocene levels (MIS 5a, c, e as in Kikai island or Huon peninsula).

Most discussions about the two most recent benchmarks (Holocene and MIS 3 ) are driven by two factors. First, Holocene and MIS 5e uplift rates are widely discrepant in some zones affected by deformation associated with great earthquakes (e.g. Lajoie, 1986; Ota and Yamaguchi, 2004; Pinegina et al., 2010, 2013, this stud). Second, only a few paleocoasts have been correlated to the MIS 3 interval. Both issues are localized in fast uplifting coasts deduced from the elevation of MIS $5 \mathrm{e}$ (Figure 4A in Pedoja et al., 2011 and Fig. 1B this study).

In the vast majority of the areas affected by co-seismic uplift, Holocene and Upper Pleistocene paleocoasts are present. The Holocene uplift rates are usually 2-3 times higher than Pleistocene rates (see Lajoie, 1986, his Figure 6.11), and at some sites even an order of magnitude higher (Pinegina et al., 2010; Pedoja et al., 2013a; Pinegina et al., 2013). However, such changes are not so apparent in other areas (e.g. from New Zealand, Papua New Guinea, Japan, Chile) (Ota and Yamaguchi, 2004; Bookhagen et al., 2006; McSaveney et al., 2006; Melnick et al., 2006). However, in some areas, uplift rate determinations might be biased because elevations and ages need to be precisely determined for those recent, mostly low-lying indicators, as uplift rates are inferred from those measurements. In addition, accuracy is exposed to uncertainties in sea-level reconstruction from considered geomorphic indicators (e.g. beach ridges in New Zealand, McSaveney et al., 2006). Finally, the eustatic sea levels have apparently varied strongly during the Holocene. Modelling studies based on field observations suggest elevations for the peak mid-Holocene highstand of up to $5 \mathrm{~m}$ above the present level (Milne et al., 2005). These elevations are at odds with reconstructions from the isotope record (Waelbroeck et al., 2002; Rohling et al., 2009). The eustatic bias over the glacial cycle can be readily exposed by considering postglacial rebound and glacio-hydro-isostasy (e.g. Peltier, 2004; Paulson et al., 2005). The time scales of viscous relaxation compare to that of the glacial cycle itself and relative sea-level change during the glacial cycle may vary dramatically from one site to another. For lowlying, recent sea-level indicators, the associated error is primordial, when only considering the absolute, uniform sea-level response to glacial cycles. For this reason, eustasy may bias the estimates of uplift rates (e.g. Briggs et al., 2008; Yildirim et al., 2013). Unfortunately, this effect will be very difficult to quantify until precise models are available at all scales based on local rheology derived from geophysical data.

Rapidly uplifting coastlines are usually associated with convergent tectonic boundaries (subduction and collision), which are commonly affected by great earthquakes. Coastal areas along such boundaries experience fast and non-uniform uplift. In a variable sense, such deformations may result from abrupt co-seismic uplift or subsidence that may be of metric-scale amplitude, in addition to transient fault after-slip, postseismic rebound, and interseismic strain buildup. Seismic cycles have various recurrence periods that range from decades to millennia. This leads to the notion that earthquakes might cluster in supercycles (Sieh et al., 2008). Indeed, variable recurrence intervals for earthquakes of different magnitudes have been deduced from paleoseismic and historical data in Chile (Cisternas et al., 2005), Sumatra (Jankaew et al., 2008) and Japan (Sawai et al., 2012), and apparently constitute a hallmark of subduction zones worldwide (e.g.: Satake and Atwater, 2007). The depth of plate-boundary slip during great subduction earthquakes is variable and may range from the trench to $>50 \mathrm{~km}$ depth (Lay et al., 2012). The locus of slip release at depth with respect to the coast dictates the sense of coseismic land-level change. Earthquakes that tend to rupture the shallow part of the megathrust, such as the M9 2011 Tohoku event, result in coastal subsidence (Sawai et al., 2012). In turn, events that rupture deeper, such as the M8.8 2010 Maule earthquake, also lead to coastal uplift (Melnick et al., 2012). Shallow and deeper earthquakes appear to have different recurrence periods. Plate coupling leading to interseismic strain accumulation usually results in reversed vertical coastal land-level changes than during coseismic strain release. 


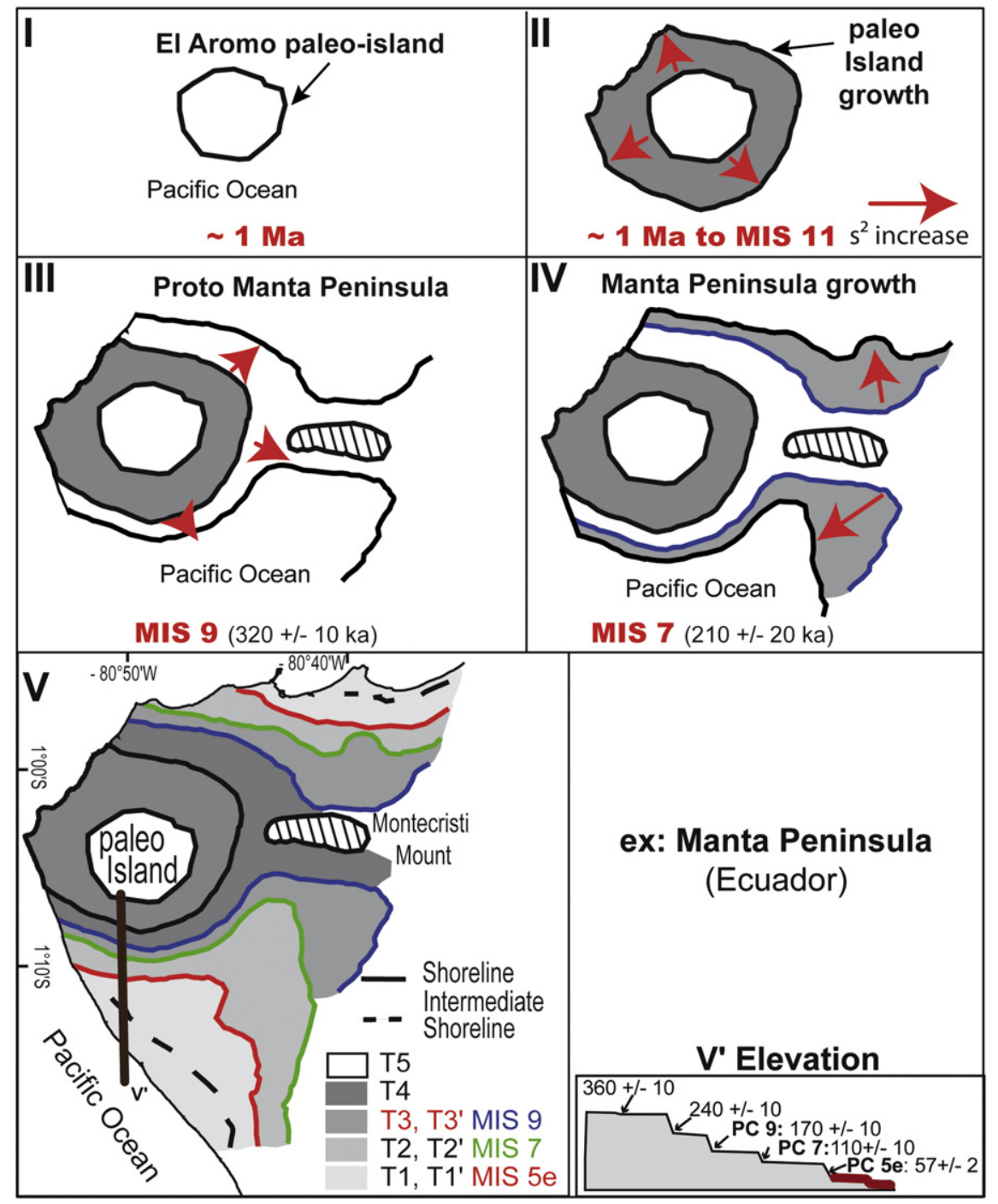

Fig. 8. From island to peninsula; example from the Manta Peninsula (Pedoja et al., 2006a,b, 2009). $S^{2}$ increase: increase in reclaimed land. Similar evolution is known in Palos Verdes Hills, California, US (Szabo and Vedder, 1971; Lajoie et al., 1991; Ludwig et al., 1992; Muhs et al., 1992; Ward and Valensise, 1994; Orme, 1998).

However, interseismic plate coupling usually occurs over a restricted depth range limited to the seismogenic zone (e.g., Wang, 2007). Therefore, in such tectonic settings the rate of Holocene uplift will be strongly influenced by the stage of the earthquake supercycle during which measurements have been made. At a local scale, the short-term Holocene vertical rate may include noise from individual seismic events, whereas the Pleistocene rate is more representative of the regional net rate of uplift that integrates many seismic supercycles as well as long-term crustal deformation (e.g. Pinegina et al., 2010, 2013). In short, we suggest that the discrepancies in Holocene-MIS 5e uplift rates may be associated with different stages of the earthquake supercycle, particularly at many sites around the seismogenic Pacific rim.

MIS 3 strandlines rarely are described along rapidly uplifting coastlines. In fact, their preservation requires both high uplift rates to overcome the fact that this highstand occurred at a deeper sea-level (with respect to today) than other episodes, and suitable materials to preserve the signal (e.g. fringing coral reef terrace). Such sequences (embedded in more complete upper and middle Pleistocene sequences) are only found in 6 areas of the circum-pacific region. All records, except for the Mahia Peninsula (New Zealand) correspond to fringing coral reef terraces. The minimum MIS 5e coastal uplift rate associated with a MIS 3 sequence of shorelines is $1.18 \pm 0.08 \mathrm{~mm} / \mathrm{yr}$ (Mahia Peninsula, New Zealand). But the relationship is not reciprocal: MIS 5e coastal uplift can be fast but MIS 3 paleocoasts are not preserved (e.g. Smith Gulf, north California or Kamchatsky Peninsula in Kamchatka). The nature of the preserved paleocoast could partly explain this, because MIS 3 terraces are narrower than MIS 5 terraces, most likely due to the short duration of the sea-level stand. Another explanation is the fact that in order to become subsequently emerged, MIS 3 strandlines had to survive some vicissitudes in lower sea level and that is a highly destructive process.

\subsubsection{Last interglacial, MIS 5e}

The most reliably dated Pleistocene strandlines along most emergent coastlines correlate with the highstand(s) during the last Interglacial maximum (MIS 5e). These constitute a significant benchmark discussed in an earlier paper (Pedoja et al., 2011). The elevation of the MIS 5e shorelines ranges from $-360 \pm 5 \mathrm{~m}$ (Hawaii Island) to $403 \pm$ $1 \mathrm{~m}$ (at site Huon Peninsula, Papua New Guinea) or $991 \pm 5 \mathrm{~m}$ (at site Franz Joseph, South Island of New Zealand, but this value as been discussed) with a mean of $27.2 \pm 2.3 \mathrm{~m}$ (updated herein, site Franz Joseph excluded from calculation). It corresponds to a mean apparent coastal uplift rate of $0.22 \pm 0.02 \mathrm{~mm} / \mathrm{yr}$. At a global scale, sequences are very rarely described in the absence of MIS $5 e$ (e.g. Ramalho et al., 2010). Sequences including all MIS 5a, 5c, 5e paleoshorelines are, together, found in rapidly uplifting areas and/or under conditions of low erosion. Such pristine sequences are described, among others, in the Vanuatu islands, in New Zealand (e.g. at Mahia peninsula for example), 


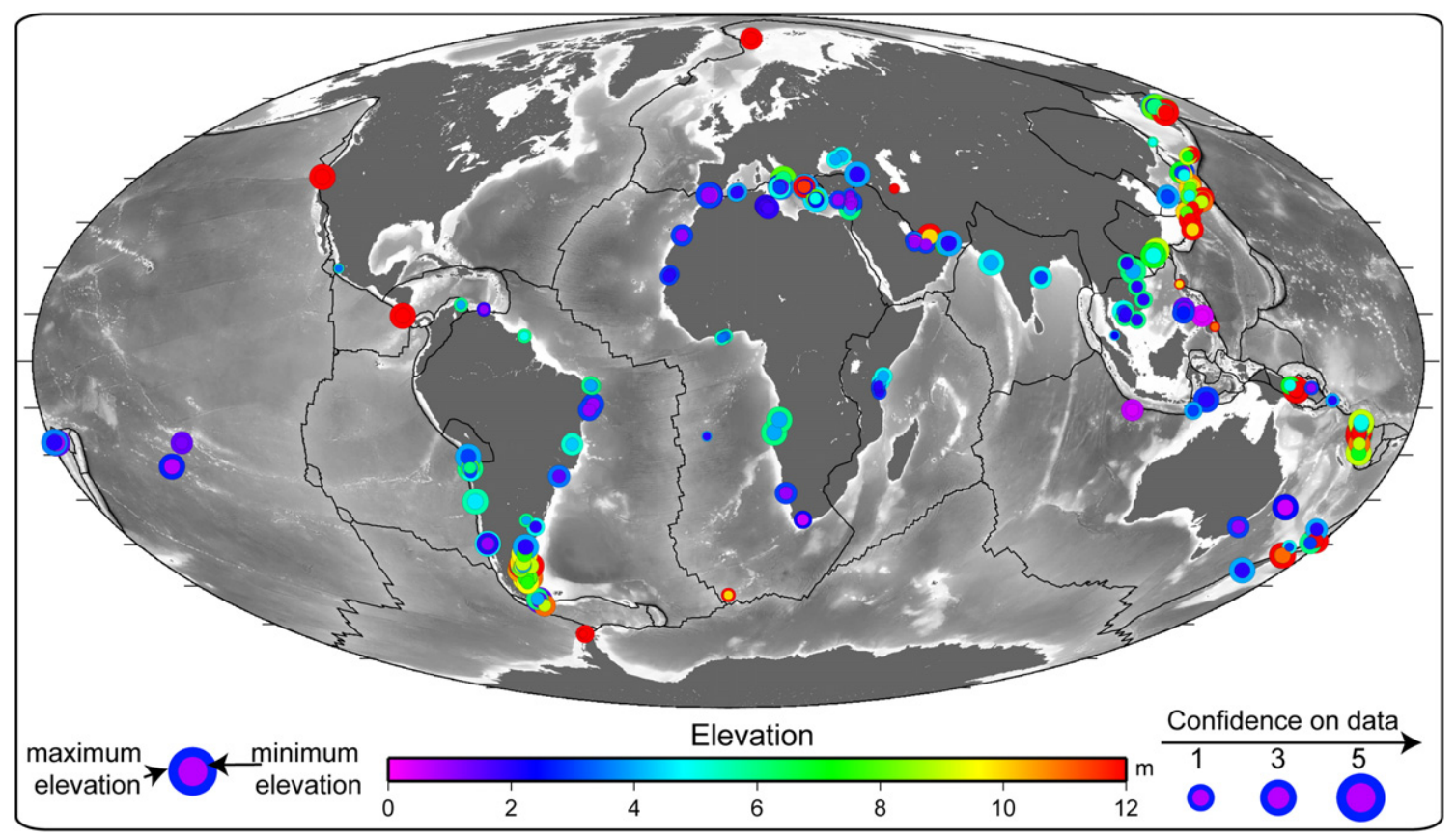

Fig. 9. Elevation of the highest Holocene shorelines from sequences that also include MIS 5e shorelines.

in northwestern US (Oregon and California), in Japan (at Kamikita), or in Italy (at Crotone and Sibari). MIS 5e coastal uplift rates as a function of the respective geodynamical settings are presented below (i.e. Section 5.3).

\subsubsection{Middle Pleistocene, MIS 7 to MIS 19}

Coastal sequences including Middle Pleistocene strandlines are extensively preserved. Best represented are the strandlines correlated with MIS 7, MIS 9, and MIS 11 . Older isotopic stages $(13,15,17,19)$ are in some cases dated or correlated to individual paleocoasts in coastal sequences. Contrary to the general belief (e.g. Zazo, 1999) that occasionally caused misinterpretation of sequences of marine terraces (e.g. Pedoja et al., 2006c), MIS 7 appears as a well-developed interglacial stage worldwide. For instance, the fact that MIS 7 was not a minor event has been suggested in Bermuda (Hearty, 2002). Locally, such as in the Gulf of Corinth (Greece) two strandlines are associated with two relative highstands during MIS 7.

MIS 11 strandlines (31 sites, Fig. 11) are less frequently described. They belong to sequences on the southern coast of Sinai (Nir, 1971; Pickett et al., 1989; Gvirtzman et al., 1992; Strasser et al., 1992;

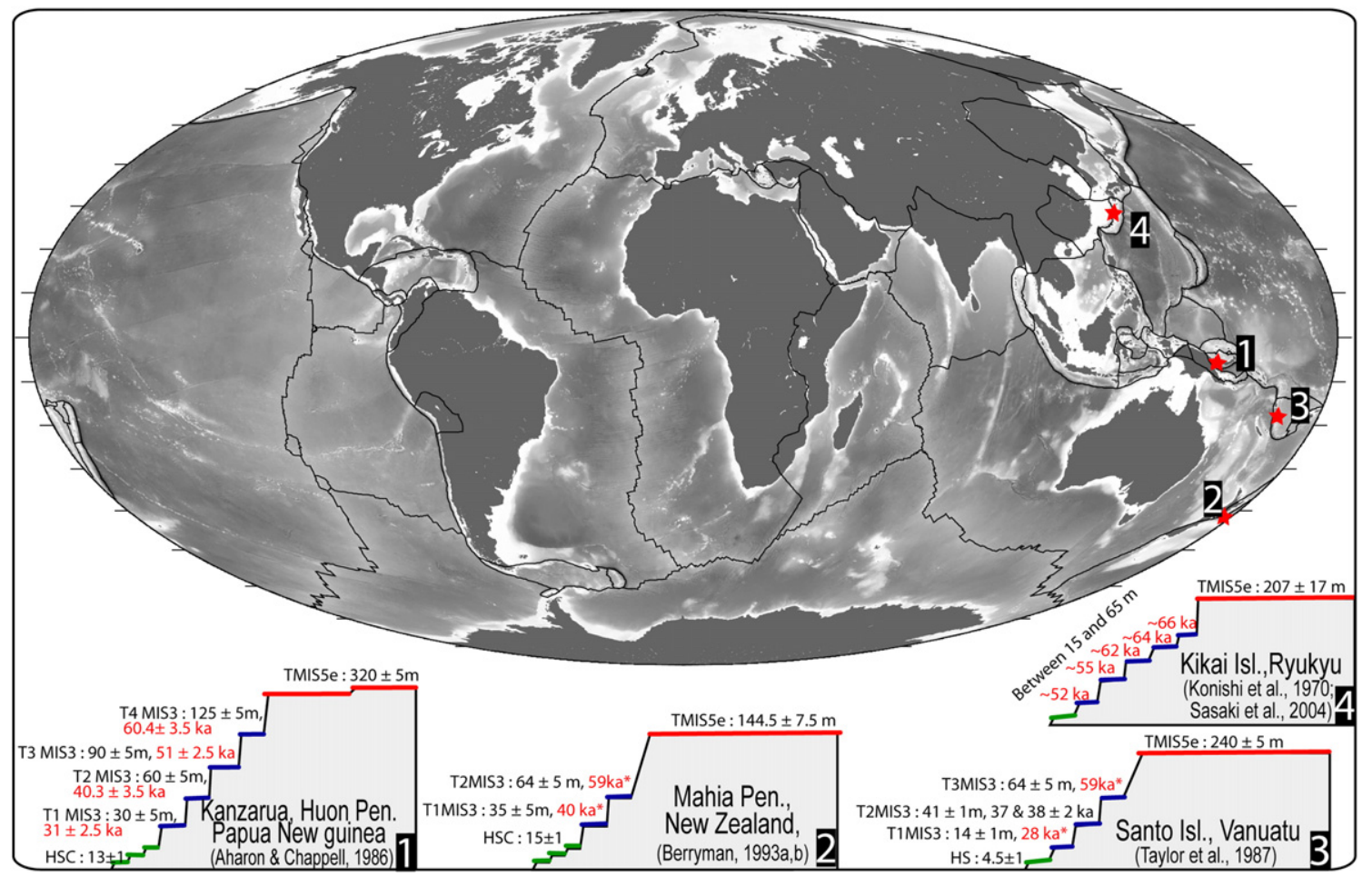

Fig. 10. Elevation of the highest MIS3 shorelines from the sequences that also include MIS 5e shorelines. Insets show the corresponding elevation profiles. 


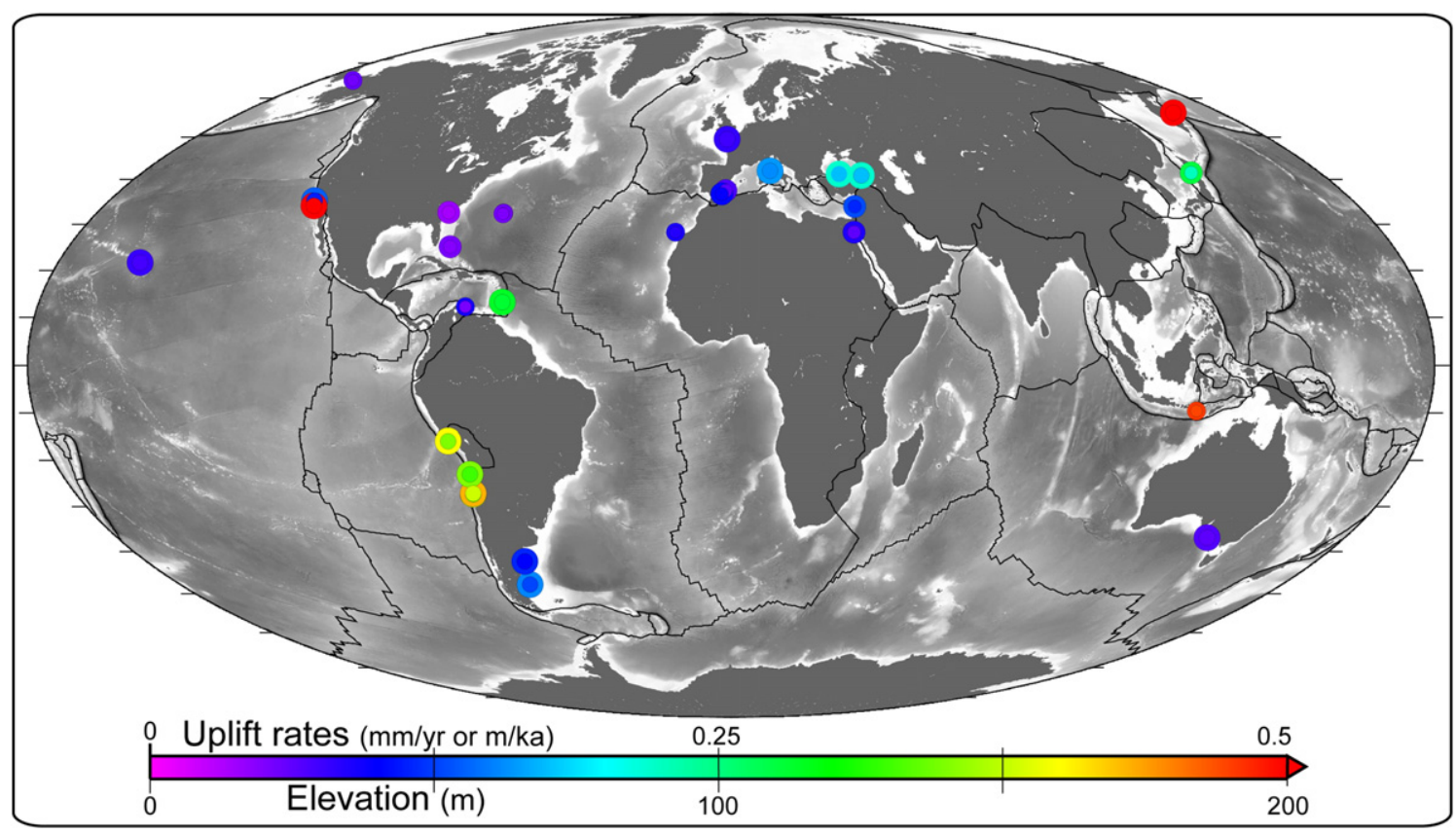

Fig. 11. Elevation of the highest MIS11 shorelines, and corresponding uplift rate, from sequences that also include MIS 5e shorelines.

El Asmar, 1997), on the coast of Peru and Ecuador (Pedoja et al., 2006b,c; Regard et al., 2010), Barbados (e.g. Muhs, 2001), on the south coast of the Black Sea in eastern Turkey (Keskin et al., 2011), on the island of Sumba in Indonesia (Boekschoten et al., 1989; Pirazzoli et al., 1993; Bard et al., 1996) in Southern Spain (e.g. Zazo et al., 2003), the Azores, on the island of Flores (Azevedo and Portugal Ferreira, 1999), on the west coast of North America (e.g. North California Hampton, 2000 and Southern California, Pinter and Sorlien, 1991; Pinter et al., 1998), the Canary Islands (Meco et al., 2002, 2007), on the island of Eleuthera in the Bahamas (e.g. Hearty and Neumann, 2001), Bermuda (e.g. Muhs et al., 2002a,b; Hearty et al., 2007), on the southern coast of England and western France (e.g. Bates et al., 1997, 2003; Coutard et al., 2006) and on the Lebanese coast (Issar and Picard, 1969; Fleisch and Sanlaville, 1974; Copeland, 2003), among others. The elevation of the MIS 11 shorelines ranges from $21 \pm 1 \mathrm{~m}$ (Grape Bay, Bermuda) to $660 \pm 60 \mathrm{~m}$ (Kamchatsky peninsula, Kamchatka) with a mean of $90.3 \pm 5.1 \mathrm{~m}$. This corresponds to a mean apparent coastal uplift rate of $0.22 \pm 0.01 \mathrm{~mm} / \mathrm{yr}$. Taking into account the margin of errors, MIS 11 uplift rates are similar to those determined from the MIS 5e benchmark (Table 1) in the tectonic context of hotspot chains, passive margins and rift zones. They differ in the context of ocean-to-ocean $(\mathrm{OO})$ plate boundaries and ocean-to-continent (OC) plate boundaries. However, the discrepancy may be easily explained by the smaller amount of data available and the higher uncertainties of age determinations for old shorelines (i.e. $400 \mathrm{ka}$, MIS 11) compared to the younger, better preserved shorelines such as those from the MIS 5e benchmark.

Regardless of the geodynamical settings, Holocene Upper and Middle Pleistocene sequences are extremely abundant relicts that record a succession of sea-level highstands. Following Chappell (1974), we clearly agree that these morphologies constitute excellent sites to study the evolution of subaerial drainage systems (Fig. 2). Such crossrelated studies (i.e. growth and incision of drainages on sequences of paleocoasts) conducted locally (Duvall et al., 2004; Rehak et al., 2010; Pedoja et al., 2013a) should be performed more systematically. Identifiable geomorphic surfaces (i.e. "terraces") provide a reference frame, allowing for tectonic uplift to be estimated from markers that control coastal landscape evolution. Thus, an organized program may 1) recognize random changes in lithology affecting the drainage system (for example coral reef terraces are formed by homogeneous limestone), 2) compare morphometric factors (asymmetry of watersheds, steepness indexes, hypsometric integral, etc.) among coastal basins sharing the same base level (sea level in these cases), and 3) correlate between morphometric parameters and tectonic uplift rates as deduced by the age and altitude of paleoshorelines (Merritts and Vincent, 1989; Snyder et al., 2000; Duvall et al., 2004; see Pedoja et al., 2013a for example of a cross-related study). Moreover, as each strandline corresponds to 1) a known isochron (timing of the seastand), 2) an isohypse, and 3) a flat surface, it seems possible to gain insight into the development of aerial drainage on these reclaimed lands. Lastly, such cross-related studies will help to quantify recent landscape evolution of the coastal fringe - one of the most densely populated areas.

\subsection{The upper part of the sequences: Lower Pleistocene-Eocene}

This large interval of time corresponds to the end of the Quaternary system (Calabrian and Gelasian stages) as well as the Neogene and a part of the Paleogene. It encompasses the highstand from MIS 21 and backward in time. The majority of the Neogene and Paleogene strandlines are described at elevations higher than $20 \mathrm{~m}$. In some cases like in Spain (Balearic Islands, Johnson et al., 2011) and Portugal (Santos et al., 2008, 2010), five Miocene shorelines are described at elevations lower than $10 \mathrm{~m}$ above modern sea level, which suggests that they are totally "disconnected" from the (possible) nearby more recent coastal sequence. Consequently, they do not seem to belong to a staircase sequence. In this geographical context, the decoupling could be linked to the Messinian crisis. Second, we used 527 extrapolated ages for the upper part of the sequences where elevations are provided. Out of these data, 388 markers suggest an initial formation age that range from the Late or Middle Pleistocene. We retained only the data that are indicative of early Pleistocene or older ages. Out of the 135 remaining sites, 104 yield lower Pleistocene ages, 12 upper Pliocene (Piacenzian, 3.6-2.6 Ma) and 10 lower Pliocene (Zanclean 5.3-3.6 Ma). Eight sites provided ages older than the Pliocene, out of which seven are Miocene (Fig. 12). In summary, only one extrapolated terrace age is seemingly older than Miocene ( $>23 \mathrm{Ma}$ ) (southern Cyprus). Again, because of the underlying hypothesis on the uplift rates and relative sea level stand at the time of formation of the uppermost terrace, these estimates should be regarded only as plausible indicators.

The results of our extrapolated ages generally fit well with published data on Neogene and Paleogene shorelines (see Supplementary data 


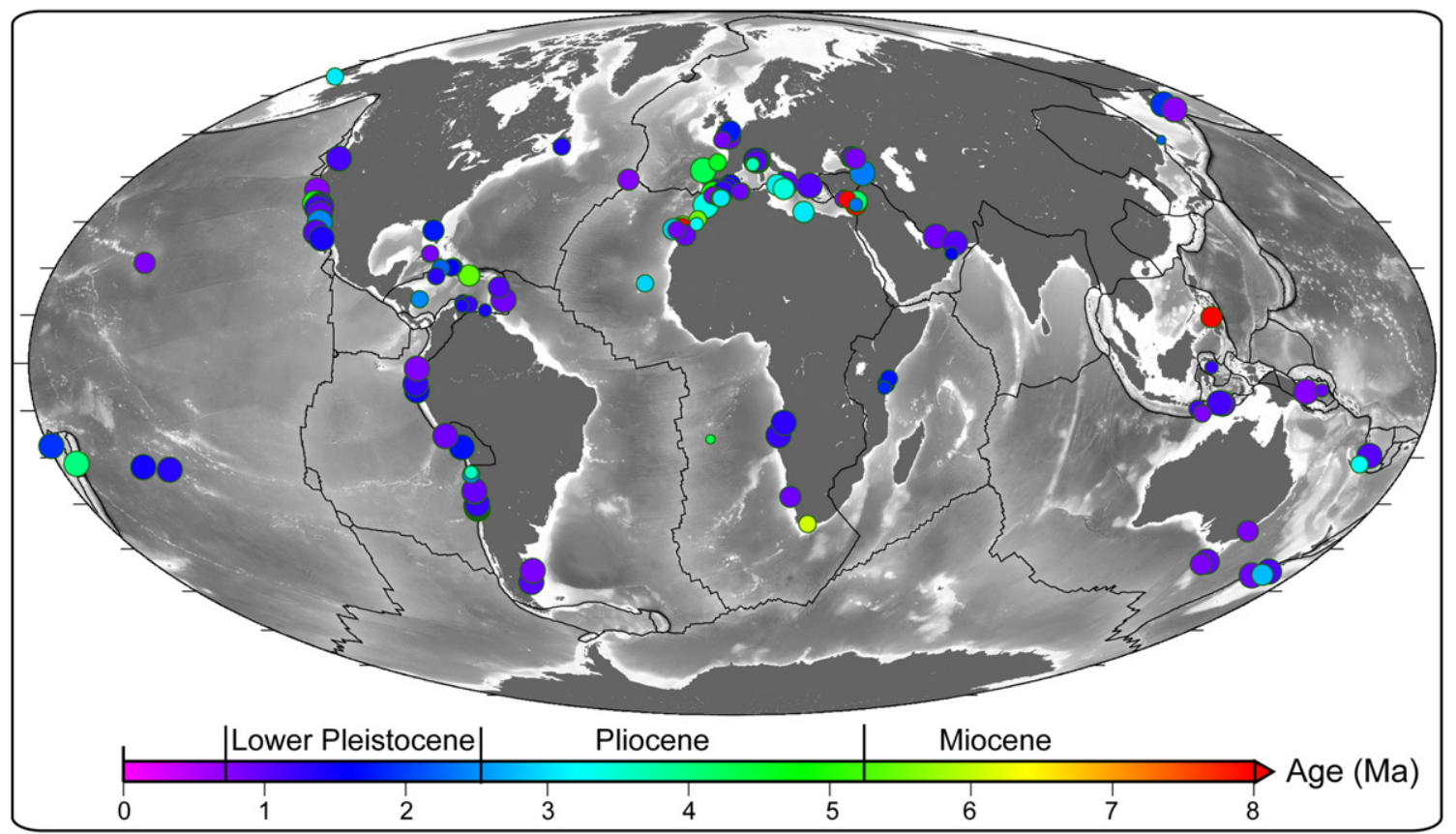

Fig. 12. Extrapolated age of the uppermost shorelines of the sequences based on MIS 5e uplift rates.

and compare Figs. 12 and 13). A good example demonstrating the plausibility of our extrapolation is at the Mare Atoll (Loyalties island) where we found an extrapolated age of 3.2 Ma and where an age of 2.6 to $3 \mathrm{Ma}$ was obtained by magneto-stratigraphic methods (Guyomard et al., 1996). When there is a discrepancy between our data and the published source, it appears that our estimates are generally younger than published ages. This is the case in northern Spain (Asturias) where our extrapolation gives an early Pleistocene age for the upper rasa at $225 \mathrm{~m}$ above mean sea level, whereas 1) it is described as Miocene (Mary, 1983), and 2) a Lower Pleistocene rasa was identified below the upper one and dated to 1-2 Ma by cosmogenic methods (Alvarez-Marrón et al., 2008) (Fig. 14).
By combining published data with our extrapolated ages for the upper shorelines in staircase sequences, we observe at a global scale in total: 1) 106 sites where the highest shoreline in the sequences correlate to the Lower Pleistocene, 2) 44 sites where the upper shoreline is Pliocene or where a Pliocene shoreline is described in a sequence, 3) 23 sites where the highest shoreline in the sequence is Miocene or where a Miocene shoreline is described in a sequence, 4) 3 sites where the highest shoreline of the sequence is Oligocene or where an Oligocene shoreline is described in a sequence, and 5) one site where the upper shoreline is Eocene.

Recent studies reveal particularly long-lasting coastal sequences that span tens of Myrs (Figs. 13 and 14): Eocene-Pliocene in the Nullarbor

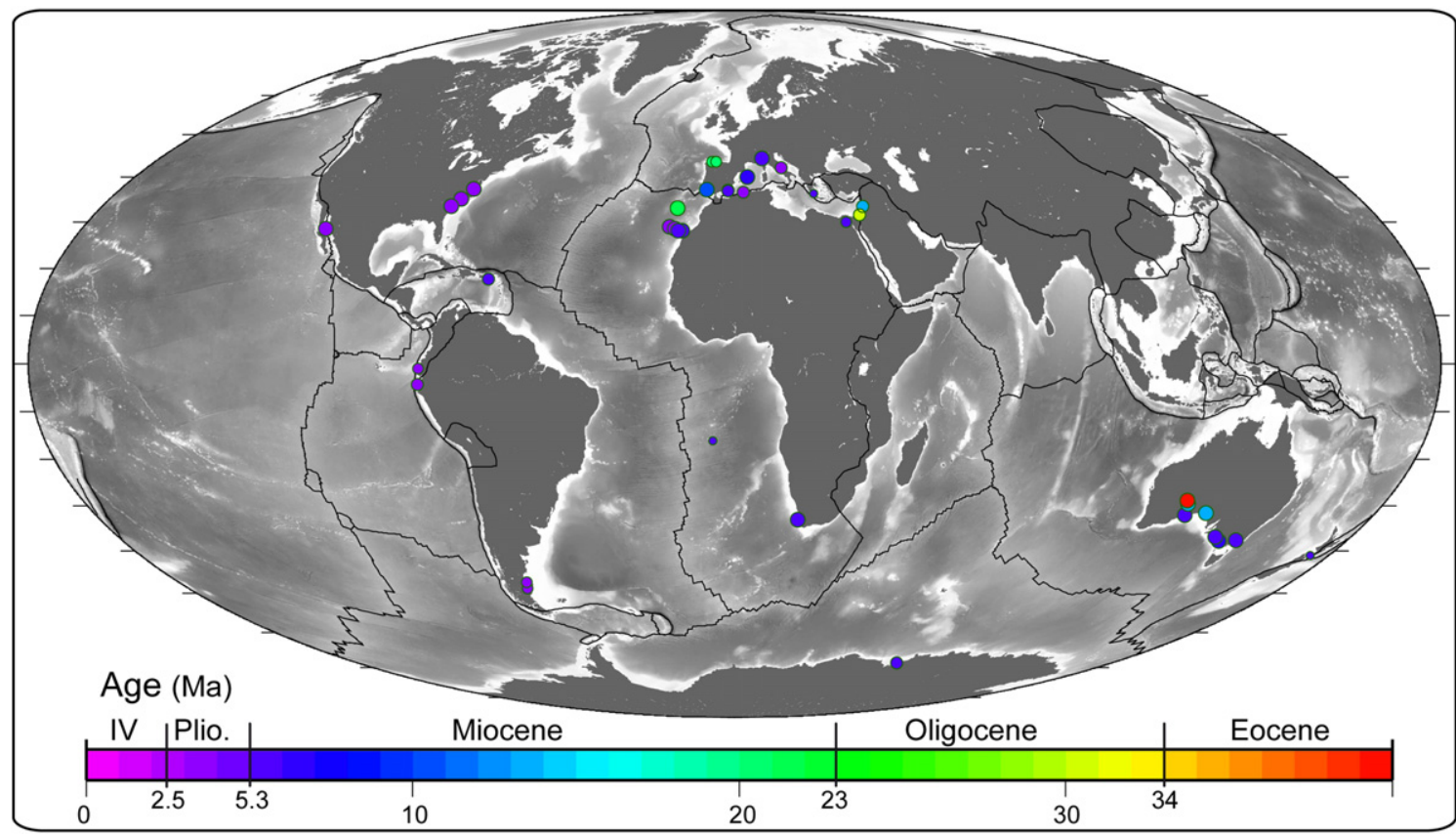

Fig. 13. Age of the oldest (i.e. older than MIS11) reported sequences, except in 5 sites (in Menorca, Madeira \& Southern Spain) all the shorelines ( 44 sites) correspond to the upper shorelines of long-lasting coastal sequences. IV: Quaternary; Plio: Pliocene. 


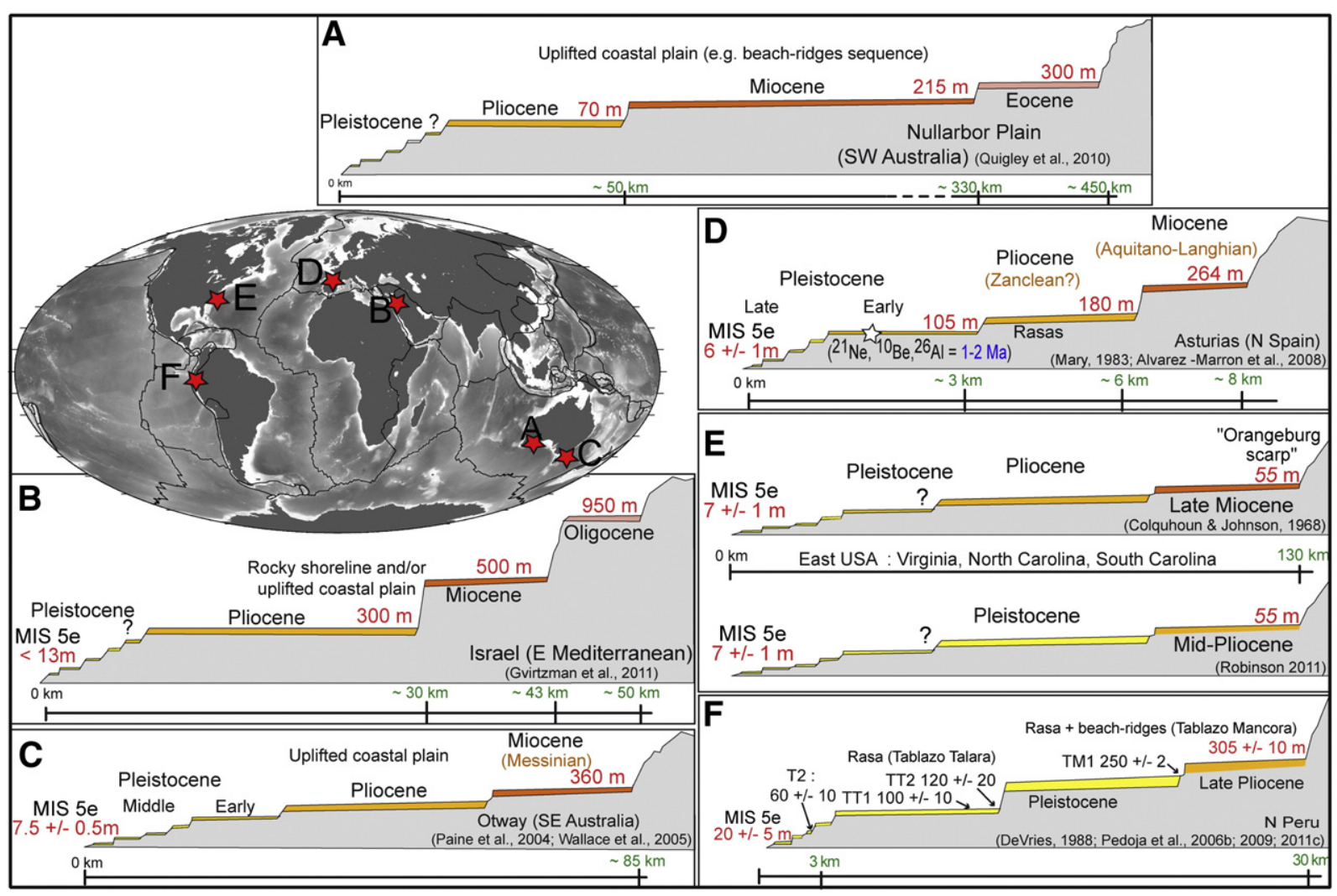

Fig. 14. Ages and topographic profiles of selected coastal sequences.

and Roe plains, SW Australia (Quigley et al., 2010); Oligocene-Upper Pleistocene in southeastern Israel, (Gvirtman et al., 2011); and Late Miocene-Holocene in the Murray Basin, Australia, (Paine et al., 2004; Wallace et al., 2005) and in southern Patagonia, Argentina (del Rio et al., 2013). In the sense they may record a single process of formation, the existence of those long-lasting sequences (i.e. older than Pliocene) are supported by two criteria. The first of these entails description and dating of Eocene to Pliocene shorelines (or sequences of shorelines) in different parts of the world such as Australia (e.g. Sandiford, 2007), Loyalties island (e.g. Guyomard et al., 1996), Canarias (Meco et al., 2007), Italy (Carobene and Cevasco, 2011), South Africa (Franceschini and Compton, 2004; Roberts et al., 2011), and Eastern Antarctica (Pickard et al., 1988). The second criteria enlists the results of extrapolations we ran in which 135 coastal sequences are supposed to be early Pleistocene or older (up to Oligocene). The extrapolation yielded Pliocene (32 data, 22 extrapolated) or Miocene (15 data, 8 extrapolated) ages. Oligocene shorelines (one datum and one extrapolation) and Eocene (one datum) shorelines are more rarely described (Figs. 13 and 14). This result is unlikely to be related to erosion.

Instead, we propose that the formation of coastal sequences was likely operative since at mininima the middle-late Miocene at a global scale and locally (regionally) since the Eocene (as in SW Australia, Sandiford, 2007; Quigley et al., 2010). Such a development was likely to have occurred during the onset of the ice sheet in Antarctica, the impact of which is currently being verified in terms of sea level (e.g. Stocchi et al., 2013). The staircase shaping of coasts increased during the Pliocene and Pleistocene as a consequence of the intensification of eustatic sea-level oscillations, as inferred from the isotopic record (Lisiecki and Raymo, 2005). Morphologically, there is nearly always a slight difference between the lower part of the sequence that formed during the Holocene to middle Pleistocene as individualized strandlines and/or compound paleocoasts as compared to the upper part (rocky or sedimentary rasa).
Changes in sea level are closely linked to the effect of Cenozoic ice sheet fluctuations (e.g. Bartek et al., 1991; Abreu and Anderson, 1998; DeConto and Pollard, 2003). However, the timing and magnitude of global sea-level changes remain controversial for the Neogene and Paleogene and more particularly during the Miocene (John et al., 2011). Recent studies demonstrate that the long-term cooling trend in the Miocene was superimposed over several punctuated periods of glaciations (named Mi-events) characterized by oxygen isotopic shifts that have been related to the waxing and waning of the Antarctic ice-sheet and bottom water cooling (e.g. Vidal et al., 2002; Holbourn et al., 2004; Westerhold et al., 2005). For example, analyzing both seismic reflections lines and sediment cores recovered from the Marion plateau (offshore Australia, ODP leg 194) John et al. (2011) identified eight individual siliciclastic-carbonate sequences between $18.0 \mathrm{Ma}$ and $11.9 \mathrm{Ma}$ and demonstrated that they are controlled by glacio-eustasy. These sequence boundaries are marked by an increase in $\delta{ }^{18} \mathrm{O}$. Westerhold et al. (2005) present a high-resolution benthic stable-oxygen isotope record for the middle to late Miocene from ODP site 1085 located in the eastern south Atlantic that reveals four $\delta{ }^{18} \mathrm{O}$ excursions between 13.8 and $10.4 \mathrm{Ma}$. The spectral analysis of the benthic $\delta{ }^{18} \mathrm{O}$ records shows strong emphasis in the $400 \mathrm{ka}$ and $100 \mathrm{ka}$ bands that reveal eccentricity-modulated variations in precession (Westerhold et al., 2005). Boulila et al. (2011) proposed that Mid-Eocene, third-order sequences are glacio-eustatically driven in response to the $1.2 \mathrm{Ma}$ obliquity cycle, suggesting that the presence of significant ice sheets precedes previous estimates (i.e. Early Eocene).

The older Eocene to Oligocene glacio-eustatic fluctuations (e.g. Abreu and Anderson, 1998; DeConto and Pollard, 2003) are rarely recorded on coasts at a global scale. The construction and preservation of a staircase sequence of strandlines requires the joint effects of sea level oscillations and tectonic uplift. Because such movements adjust at the plate tectonic time-scale, this condition is available for many tens of millions of years, only waiting for the onset of the glacial cycle. 
A comprehensive survey of Cenozoic eustasy is beyond the scope of the present paper, but we suggest that glacio-eustasy began to profoundly shape coastlines since the Middle to Late Miocene and regionally since the Eocene.

\section{The geodynamics of strandlines}

\subsection{Settings}

At a global scale, plate tectonics provide the kinematic model that best describes the response of the Earth's surface to internal dynamics. It assumes that lithospheric plates, either continental or oceanic, move over the surface of the Earth without deforming. The lithospheric plates ride on the asthenosphere and move respective to one another along three main types of plate boundaries: convergent, divergent, and transform. In practice, the definition of a geodynamic setting is rendered problematic by the fact that the transition from one regime to another is rather continuous, and that they furthermore can evolve through time. For example, passive margins can be reactivated and become active margins. Divergent plate margins tend to produce passive margins on their edges, etc. We nevertheless distinguish 8 main geodynamic settings, either intraplate or located at plate margins. In addition, a supplementary class of undefined settings (referred to as ND) was included for 31sites where MIS 5e elevations are known and 12 sites where elevation of Holocene strandlines are known. Because of the idiosyncrasies at many sites, the distinction is subjective and could not be performed automatically.

Intraplate settings encompass passive margins PM and hotspots HS. Passive margins are defined as the transition between oceanic and continental crust that was originally created by rifting. Hotspots are volcanic regions fed by the underlying hot mantle remote from plate boundary zones. Plate motion over the hotspot source (presumed stationary in the mantle) results in the creation of hotspot volcanic chains. At plate boundaries, the relative motions between lithospheric plates can be classified as divergent, transform and convergent. Divergent plate margins occur where two tectonic plates are either separated by continental rifts (CR) or by mid-oceanic spreading ridges. Of course, ridges lie below sea level and only one site is documented in the Azores, where the interaction with the hotspot explains its aerial exposure. Divergences in continental areas result in the construction of a continental rift that transitions into two opposite passive margins separated by oceanic crust. A transform margin (TR) forms where two plates move alongside each other. Convergent boundaries, or active margins, are often actively deforming coastal regions. Earthquakes and volcanoes are common near convergent boundaries. We distinguished among oceanic plates that subduct underneath oceanic plates (00, Mariana type), continental plates that subduct underneath oceanic plates (CO, Banda type), oceanic plates that subduct underneath continental plates (OC, Nazca type) and lastly, collision of two continental plates (CC).

\subsection{Results}

Here we present the coastal uplift rates derived from the elevation of the MIS 5e paleoshoreline as a function of the geodynamic setting (Figs. 15, 16 and 17). Those values are apparent uplift rates due to the fact that we do not account for any a priori eustatic change in sea level. The average values provided are only indicative, because they are equally weighted for all areas regardless of spatial extent or data density.

Classic cases of sequences of paleoshorelines located in hotspot (HS) settings are found among 15 hotspot chains (e.g. Hawaii, Reunion, Kiribati, Cape Verde, Canary...) (Fig. 15). MIS 5e markers are present in 51 sequences. Our benchmarks range from $-360 \pm 5 \mathrm{~m}$ (Hawaii island, Site NW Hawaii) to $155 \pm 15 \mathrm{~m}$ (crater on Lanai Island, Hawaii archipelago, site Lanai Crater) with a mean of $1.3 \pm 2.1 \mathrm{~m}$. Consequently, Late Pleistocene rates average $0.01 \pm 0.01 \mathrm{~mm} / \mathrm{yr}$. Holocene strandlines are present at 5 sites located in HS settings and the mean elevation of the highest Holocene shoreline is found at $1.6 \pm 0.6 \mathrm{~m}$. MIS 11 shorelines ( 4 sites) have a mean of $26.7 \pm 1 \mathrm{~m}$ and a consequent meanuplift rate of $0.07 \pm 0.01 \mathrm{~mm} / \mathrm{yr}$ for the last $400 \mathrm{ka}$.

Passive margins (PM) are the setting where Quaternary coastal sequences are most often described in the literature. We identified 14 coastal areas with 337 sequences including MIS 5e. Among these sequences, 62 also include MIS 1 paleoshorelines and 9 MIS 11 paleoshorelines (Figs. 9, 11, 15 and 18). For the MIS 5e marker, only 20 sites correspond to submerged sites and this coastal benchmark ranges between $-116 \pm 6 \mathrm{~m}$ (site Emilia-Romagna, Italy) to $88 \pm 4$

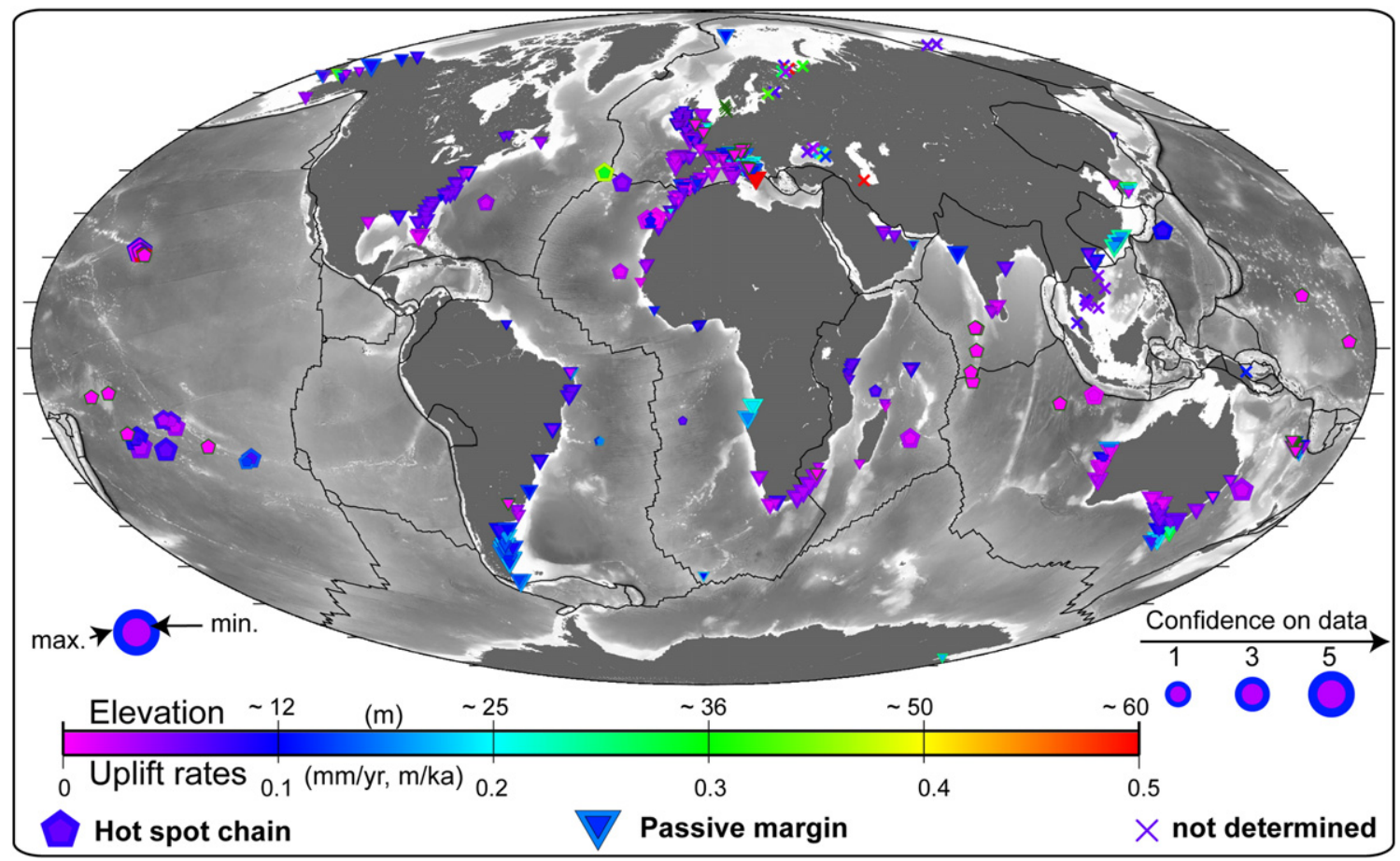

Fig. 15. Mean elevation of MIS5e paleoshorelines and coastal uplift rate since Upper Pleistocene as a function of geodynamics for hot spots, passive margins and not determined. 


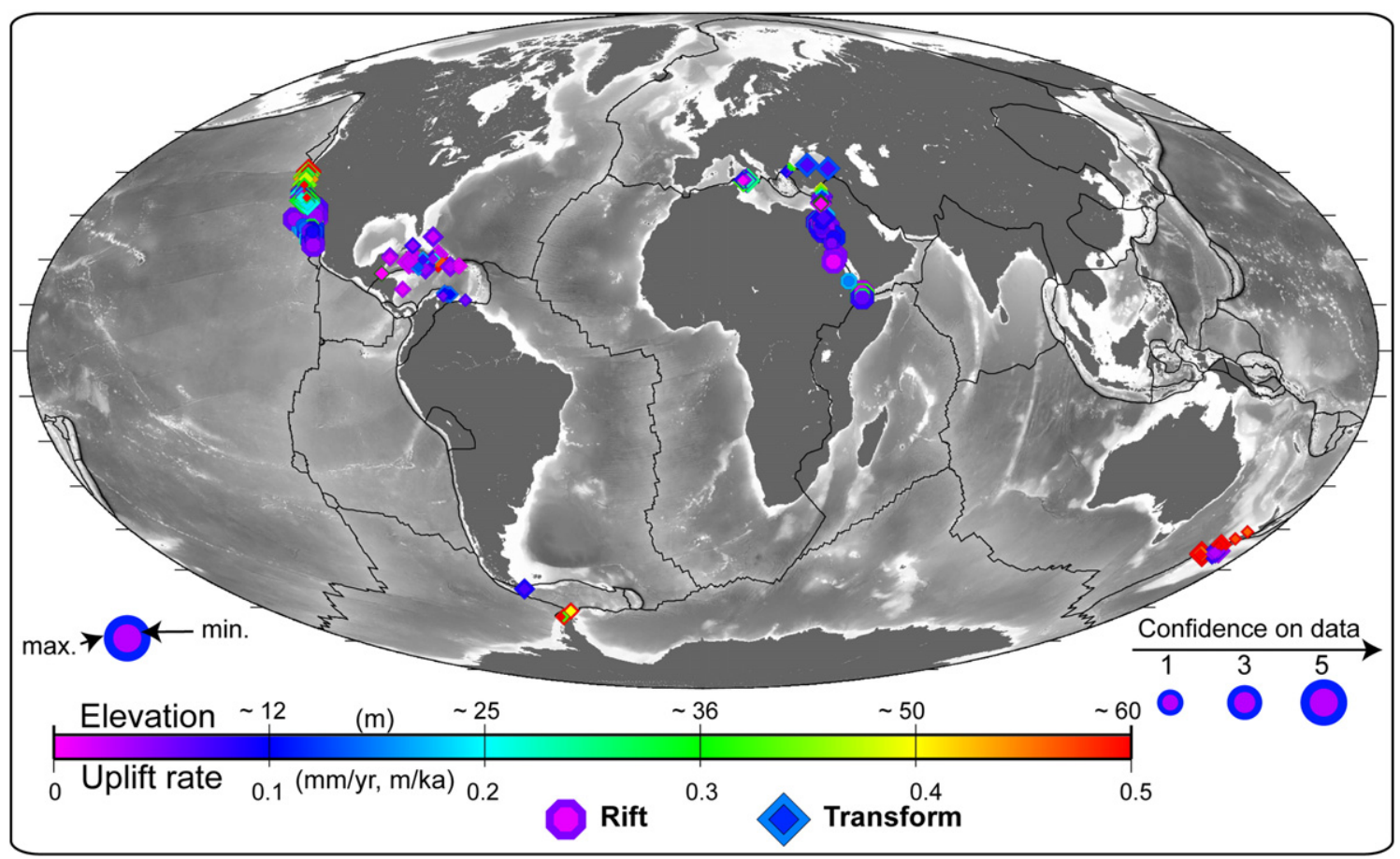

Fig. 16. Mean elevation of MIS5e paleoshorelines and coastal uplift rate since Upper Pleistocene as a function of geodynamics for transform plate boundaries and continental rifts.

$\mathrm{m}$ ( site Locri, Italy) with a mean of $\sim 6.9 \pm 1.7 \mathrm{~m}$. The mean late Pleistocene uplift rate is $0.06 \pm 0.01 \mathrm{~mm} / \mathrm{yr}$. Holocene strandlines associated with their Pleistocene counterparts show elevations ranging between 1.5 and $37 \mathrm{~m}$ yielding a mean elevation of $5.3 \pm 1 \mathrm{~m}$. The highest Holocene shoreline ( $37 \mathrm{~m}$ ) associated with a MIS 5e shoreline is found in Svalbard where post-glacial rebound is extremely efficient. MIS 11 shorelines ( 9 sites) range from $15 \pm 1 \mathrm{~m}$ to $63 \pm 1 \mathrm{~m}$ with a mean of $36 \pm 1.7 \mathrm{~m}$ and a mean uplift rate of $0.09 \pm 0.01 \mathrm{~mm} / \mathrm{yr}$ for the last
$400 \mathrm{ka}$. Older shorelines (i.e. from early Pleistocene to Eocene) are preferentially found at passive margins.

Staircase sequences of paleoshorelines on continental rifts (CR) are exemplified by the East African Rift and the Baja California rift zones (Fig. 16). These two continental rifts (CR) exhibit a total of 56 sites where the elevation of MIS 5e is known. Paleoshoreline elevations range from $0.5 \pm 1 \mathrm{~m}$ to $43 \pm 1 \mathrm{~m}$ with a mean of $13.5 \pm 1.2 \mathrm{~m}$, yielding a mean apparent uplift rate of $0.11 \pm 0.01 \mathrm{~mm} / \mathrm{yr}$. More precisely the

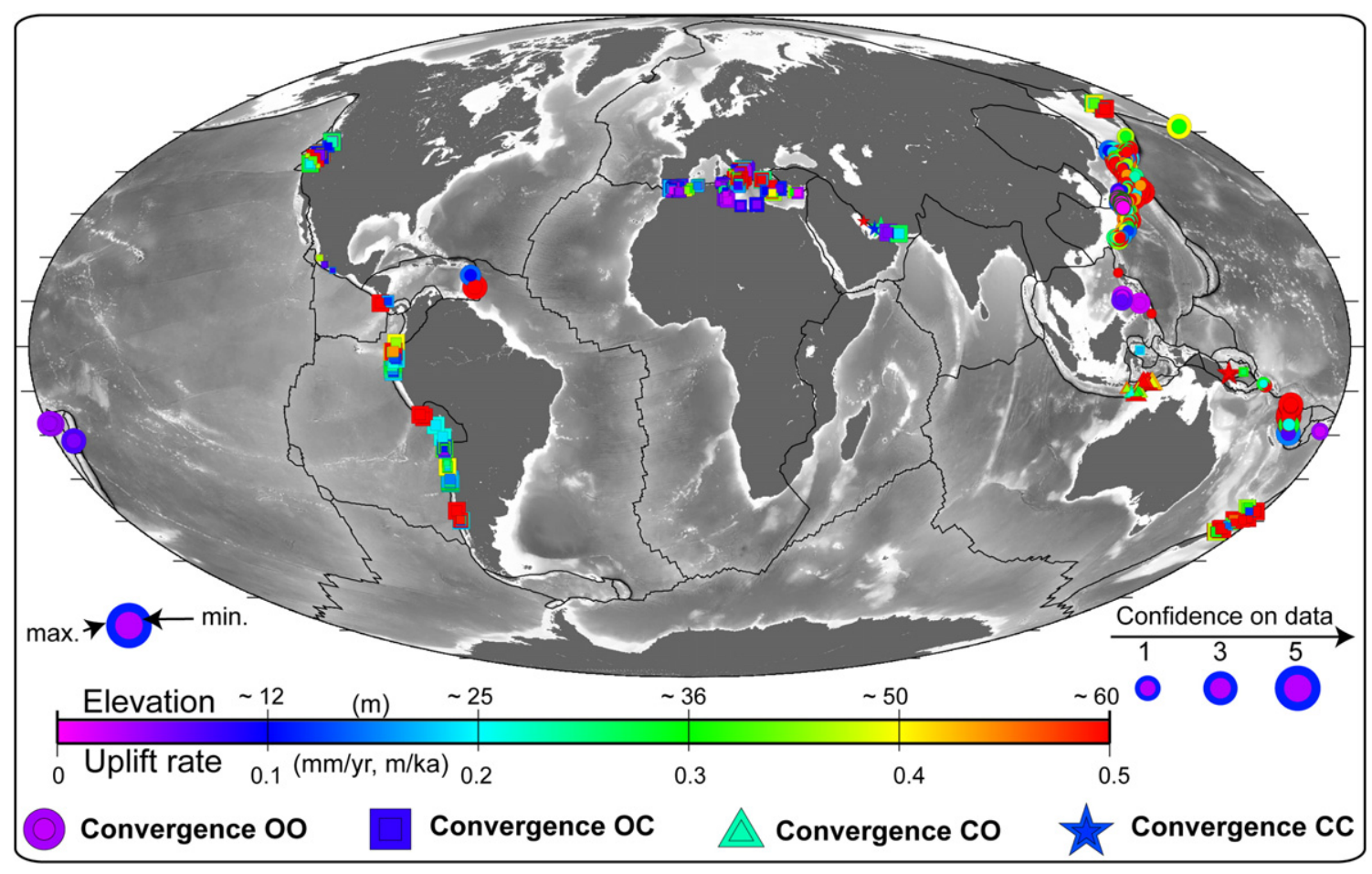

Fig. 17. Mean elevation of MIS5e paleoshorelines and coastal uplift rate since Upper Pleistocene as a function of geodynamics for ocean-ocean (OO), ocean-continent (OC), continentocean (CO) and continent-continent (CC) convergent zones. 


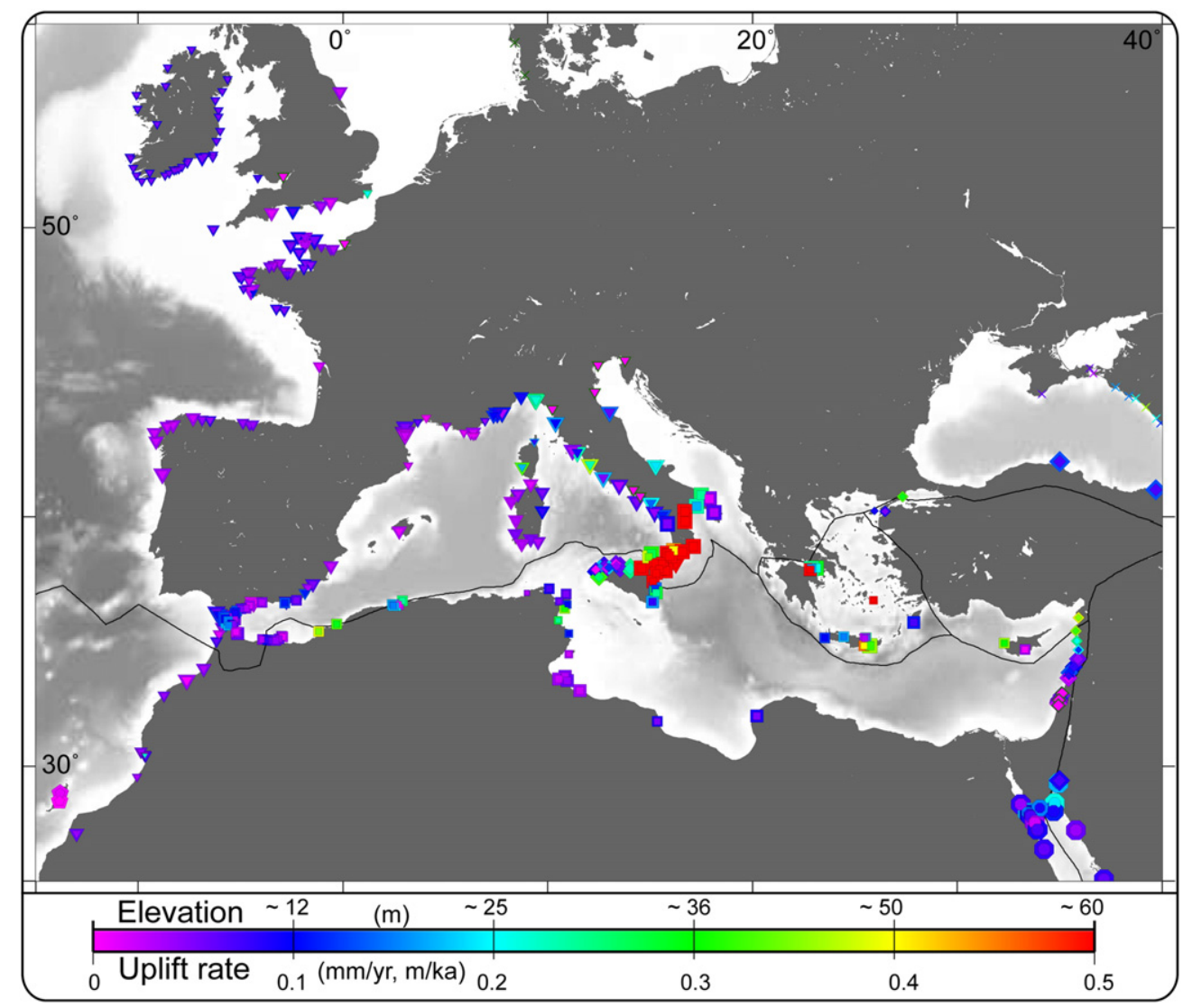

Fig. 18. Mean elevation of MIS 5e paleoshorelines and coastal uplift rate since Upper Pleistocene as a function of geodynamics in Europe. See Figs. 15,16 and 17 for symbols.

MIS 5e benchmark is identified in 29 sites along the coast of the Red Sea. They vary from $0.5 \pm 1 \mathrm{~m}$ (site Tawila SE) to $36 \pm 1 \mathrm{~m}$ (site Obock in Djibuti) with a mean of $11.7 \pm 1.1 \mathrm{~m}$. Coastal sequences also extensively are present on both sides of the Sea of Cortez, to the west on the Baja California peninsula and to the east on the coast of Sonora (Figs. 16 and 19). In this area, coastal sequences including the MIS 5e benchmark

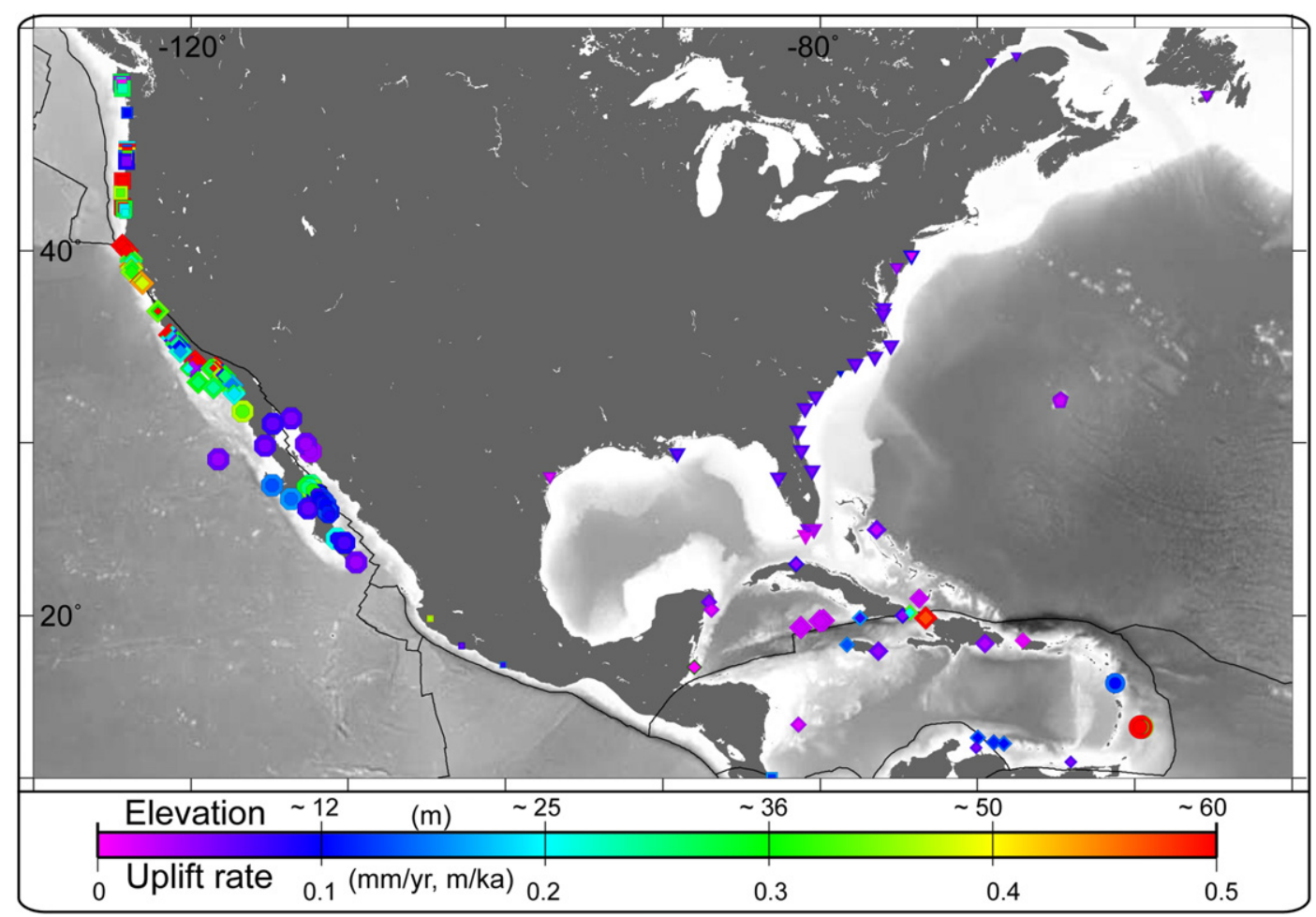

Fig. 19. Mean elevation of MIS 5e paleoshorelines and coastal uplift rate since Upper Pleistocene as a function of geodynamics in North America. See Figs. 15 , 16 and 17 for symbols. 
are described from 27 sites with elevations ranging from $4.5 \pm 0.5 \mathrm{~m}$ (site Puerto Lobos-Kino) to $43 \pm 1 \mathrm{~m}$ (at Punta Banda) with a mean of $15.3 \pm 1.2 \mathrm{~m}$. Holocene strandlines in a rift setting have been described at one site in the Sinai, where it is present at an elevation of $0 \pm 1 \mathrm{~m}$. The MIS 11 shoreline is identified at one site (Red Sea) at an elevation of $30 \pm 5 \mathrm{~m}$, which implies a consequent mean apparent uplift of $0.08 \pm 0.01 \mathrm{~mm} / \mathrm{yr}$ for the last $400 \mathrm{ka}$.

The San Andreas Fault in California is the most famous example of a transform boundary ( $\mathrm{Tr}$ ), but six other transform boundaries exhibit coastal sequences (e.g. southern Island of New Zealand, Eastern Mediterranean Sea, central Carribean...). The MIS 5e coastal benchmark is found at 121 sites, out of which 3 are submerged (Fig. 16). Note that, as in Pedoja et al. (2011), we excluded the Franz Joseph site on the South Island of New Zealand, because of the controversial elevation of the MIS 5e shoreline (Bull and Cooper, 1986, 1988; Ward, 1988). MIS 5e coastal elevations range from $-5 \pm 5 \mathrm{~m}$ (Belize Island) to $275 \pm$ $25 \mathrm{~m}$ (at Smith Gulf, California) with a mean of $\sim 30.5 \pm 3 \mathrm{~m}$. Consequently, the mean Late Pleistocene apparent uplift rate is $0.25 \pm$ $0.02 \mathrm{~mm} / \mathrm{yr}$. Holocene strandlines are present at 17 sites on coasts located in a transform or strike slip context. The mean elevation of the highest Holocene shoreline is $6.6 \pm 1.0 \mathrm{~m}$. MIS 11 shorelines ( 7 sites) range from $20 \pm 1 \mathrm{~m}$ to $230 \pm 10 \mathrm{~m}$ with a mean of $76.1 \pm 6 \mathrm{~m}$ and a consequent mean apparent uplift rate of $0.19 \pm 0.02 \mathrm{~mm} / \mathrm{yr}$ for the last $400 \mathrm{ka}$

We distinguished four main types of convergent zones depending on the nature of converging plates (Fig. 17).

On coasts located in front of oceanic plates where subduction occurs underneath continental plates (OC, Nazca type), we distinguish 7 domains (e.g. South West America, NW America, Kamchatka), from which 174 sequences include an emerged MIS 5e benchmark. The elevation of these MIS 5e shorelines ranges from $0 \pm 1 \mathrm{~m}$ to $330 \pm 20 \mathrm{~m}$ with a mean of $\sim 45.3 \pm 3 \mathrm{~m}$. Consequently, the mean Late Pleistocene coastal uplift rate is $0.37 \pm 0.03 \mathrm{~mm} / \mathrm{yr}$. Holocene strandlines are present at 41 sites and the mean elevation of the highest Holocene shoreline is $5.6 \pm 0.9 \mathrm{~m}$. MIS 11 shorelines ( 5 sites) are found at a mean elevation of $241 \pm 15$, yielding a consequent mean apparent uplift rate of $0.67 \pm$ $0.06 \mathrm{~mm} / \mathrm{yr}$ for the last $400 \mathrm{ka}$.

On coasts located in front of oceanic plates that are subducting underneath oceanic plates (OO, Mariana type) (Figs. 17 and 20), we distinguish 4 domains (east Caribbean, West Pacific, Philippines, Japan-Aleutian) where 142 sequences include the MIS 5e benchmark. Eleven sites correspond to submerged shorelines and the elevation of MIS 5e shorelines range from $-85 \pm 2.5 \mathrm{~m}$ to $240 \pm 3 \mathrm{~m}$ with a mean of $\sim 51.3 \pm 3.1 \mathrm{~m}$. Consequently, the mean Late Pleistocene coastal uplift rate is $0.42 \pm 0.03 \mathrm{~mm} / \mathrm{yr}$. Holocene strandlines are present at 35 sites and the mean elevation of this highest Holocene shoreline is $8.2 \pm$ $1.1 \mathrm{~m}$. MIS 11 shorelines ( 3 sites) are found at a mean altitude of $111 \pm$ $4 \mathrm{~m}$ and a lower mean apparent uplift rate of $0.28 \pm 0.02 \mathrm{~mm} / \mathrm{yr}$ for the last $400 \mathrm{ka}$.

On coasts located in front of continental plates subducting underneath oceanic plates ( $\mathrm{CO}$, Banda type), we distinguish one domain (South Sunda) where 13 sequences include the MIS 5e benchmark (Fig. 17). MIS 5e shorelines emerge at elevations ranging from $10 \pm 1$ $\mathrm{m}$ to $180 \pm 3 \mathrm{~m}$ with a mean of $\sim 66 \pm 2.7 \mathrm{~m}$. with a mean Late Pleistocene coastal apparent uplift rate of $0.54 \pm 0.04 \mathrm{~mm} / \mathrm{yr}$. Holocene strandlines are present at 2 sites and the mean elevation of the highest Holocene shoreline is $3 \pm 0.5 \mathrm{~m}$. A MIS 11 shoreline is found on Sumba Island at an altitude of $190 \pm 1 \mathrm{~m}$, giving a consequent mean apparent uplift rate of $0.48 \pm 0.02 \mathrm{~mm} / \mathrm{yr}$ for the last $400 \mathrm{ka}$.

On coasts located in front of the collision of two continental plates (CC), we distinguish 2 domains (i.e. Huon Peninsula in Papua New Guinea and South Iran) where 10 sequences include an emerged MIS 5e benchmark (Fig. 17). The elevation of MIS 5e shorelines range from $15 \pm 1 \mathrm{~m}$ to $403 \pm 1 \mathrm{~m}$ with a mean of $179.3 \pm 3.5$ and a mean Late Pleistocene coastal apparent uplift rate of $1.47 \pm 0.08 \mathrm{~mm} / \mathrm{yr}$. Holocene strandlines are present at 8 sites and the mean elevation of the highest Holocene shoreline is $14.1 \pm 1 \mathrm{~m}$. MIS 11 shorelines have not been identified in such settings.

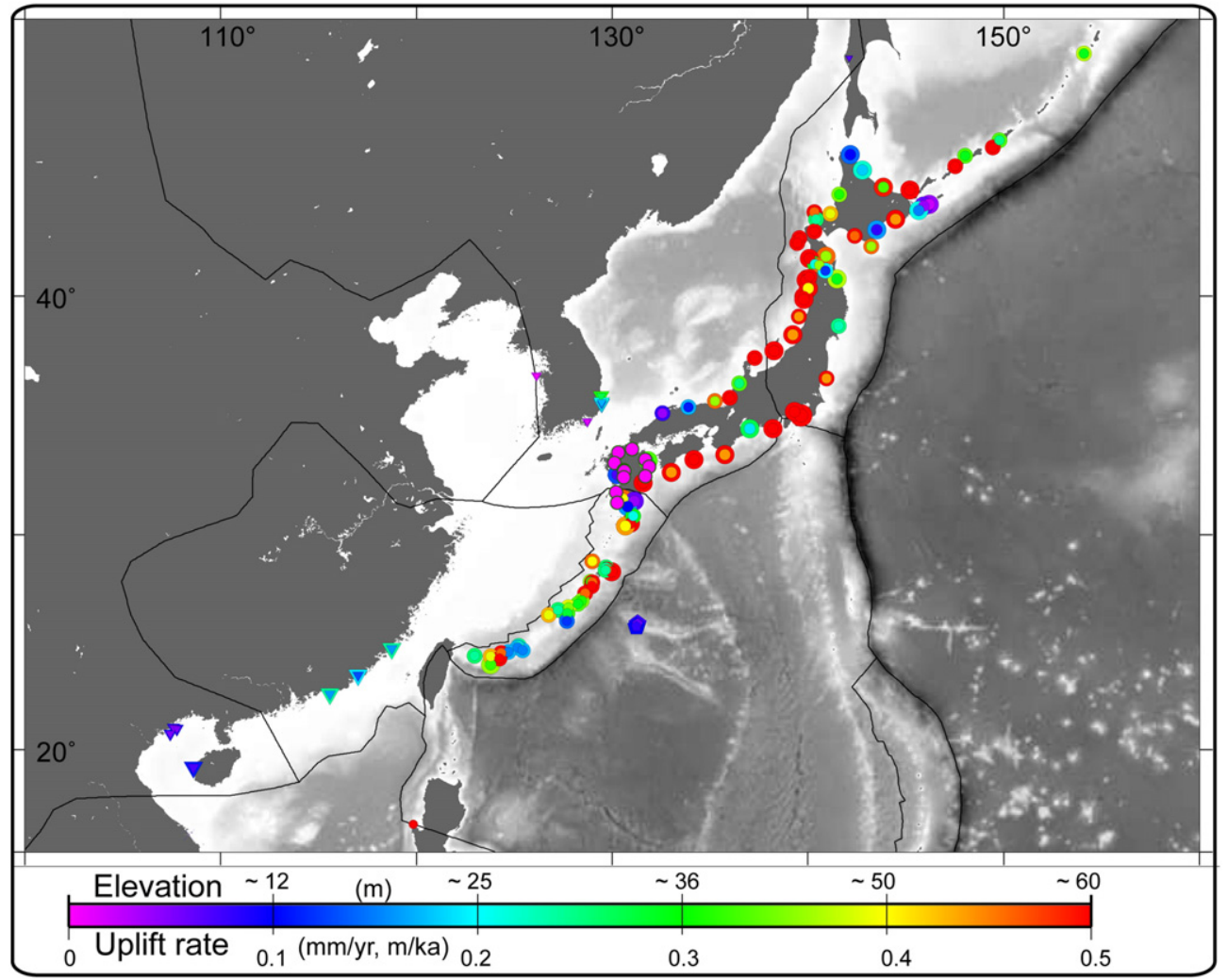

Fig. 20. Mean elevation of MIS 5e paleoshorelines and coastal uplift rate since the late Pleistocene as a function of geodynamics in Asia. See Figs. 15,16 and 17 for symbols. 


\subsection{Apparent uplift rates and geodynamics}

All coastlines feature an apparent coastal uplift during the Quaternary and Neogene, regardless of the geodynamic settings. The fact that the coastal sequences are similar in diverse dynamic, geomorphological, physiographic as well as geological settings calls for a unique mechanism overall. Yet, the causes remain poorly understood. We previously advocated that this apparent uplift could result from an increasing generalized compression of continents during the Cenozoic (Pedoja et al., 2011). This would result in the compression of any margin, and uplift would be symptomatic (Yamato et al., 2013). We dismissed alternative mechanisms, such as dynamic uplift as a response to mantle flow or post-glacial rebound. The first potential alternative leads equally to either uplift or subsidence, unlike the pattern of apparently ubiquitous uplift that we found. The second potential alternative is not capable of universal uplift on all coastlines. Above all, this scenario for uplift would not persist from one glacial cycle to another but rather would be followed by subsidence prior to uplift during the following cycle.

Alternatively, sea level drop could be envisioned as a forcing mechanism in opposition to ground motion. Eustasy caused by a decreasing volume of water clearly has contributed to this scenario at least since the last $5 \mathrm{Ma}$, as suggested by the oxygen isotopic record (Lisiecki and Raymo, 2005). However, models suggest that sea-level height during interglacial maxima did not exceed the present-day height by more than a few meters (Bintanja and Van de Wal, 2008) for the last 2.9 Ma, and possibly around $25 \mathrm{~m}$ during the Mid-Pliocene Warm Period (2.9 Ma to 3.3 Ma) and earlier (Raymo et al., 2011). If glacio-eustasy were to be the overall mechanism, emerged portions of coastal sequences would be older than $2.9 \mathrm{Ma}$, in contradiction to the widespread occurrence of many younger markers above present-day sea level. Lastly, eustastic changes caused by time variations in the shape of oceanic basins are insufficient, because the changes are too small over comparatively short spans of time. All possible mechanisms (ridge volume, sediment infill, continental contraction or seafloor volcanism and dynamic topography) yield sea level drops that depart from the observed rate by an order of magnitude (see review by Conrad, 2013).

However, some differences are notable and the various settings can be classified as a function of their Upper Pleistocene coastal uplift rate. In an ascending order (increasing apparent uplift rate), the results from Table 1 read: Hotspot Chain (HS $0.01 \pm 0.01 \mathrm{~mm} / \mathrm{yr}$ ), Passive Margin (PM $0.06 \pm 0.01 \mathrm{~mm} / \mathrm{yr}$ ), Rift (R $0.11 \pm 0.01 \mathrm{~mm} / \mathrm{yr}$ ), Transform (TR $0.25 \pm 0.02 \mathrm{~mm} / \mathrm{yr}$ ) and Convergent subdivided in $\mathbf{O C}(0.37 \pm$ $0.03 \mathrm{~mm} / \mathrm{yr}), 00(0.42 \pm 0.03 \mathrm{~mm} / \mathrm{yr}), \mathbf{C O}(0.54 \pm 0.04 \mathrm{~mm} / \mathrm{yr})$, CC $(1.47 \pm 0.08 \mathrm{~mm} / \mathrm{yr})$.

Along convergent margins, the way in which forearc dynamics relates to the geometric and dynamic parameters of the subduction system remains poorly known. Uncertainties about the evolution of forearc areas underscore the fact that little or no straightforward relationships have been found between the deformation of forearc and plate kinematics (Hartley et al., 2000; Houston et al., 2008). Uplift and subsidence, erosion and detritical paroxysms poorly match changes in plate convergence both in time and space (Hartley et al., 2000; Houston et al., 2008). Additional difficulties arise from the fact that several subduction-related processes may cause comparable rates of uplift or subsidence. In a general manner, forearc uplift must at first relate to the coupling between the two converging plates. This, in turn is regulated by the lithospheric and crustal rheologies, the thermal regime, and other factors. A careful overview of such aspects is beyond the scope of this paper but they have been regarded as effective factors in generating uplift in forearc areas. Not surprisingly, continent-continent regimes (CC) display the highest uplift rates that are most likely caused by tectonic shortening. The collision of Australia against SE Asia (CO) has triggered a fast uplift of the Indonesian arc, because the continental subducting plate forces the upper plate to rapidly deform. Ocean-ocean convergence (00) is also accompanied by fast uplift rates of the adjacent islands, in spite of the global extension of the back-arc basins.
This is, of course, due to the tectonic compression, at least, in the accretionary wedge (when present) that accompanies any subduction zone regardless of the general extensional regime. Lastly, ocean-continent subduction zones $(\mathbf{O C})$ uplift at fast rates, too. There, the mechanisms are less clear as they result from the combination of co-seismic uplift (e.g. as in Vanuatu, see Taylor et al., 1980), tectonic shortening of the upper plate, crustal underplating, and magmatic addition. Overall, these mechanisms all combine to promote uplift on the various plate margins.

Uplift along passive margins is a process that significantly postdates rifting (i.e. Japsen et al., 2006). Difficulties in relating coastal uplift to the dynamics of passive margins may lie in the fact that these (specially drifted passive margins) may show very low exhumation and denudation rates over long periods of time. Thus, as suggested by Gallagher and Brown (1999) the dominant surface process in the onshore region is denudation, which acts to remove any direct evidence of surface uplift. Deep processes such as post-rift magmatic underplating and dynamic support also have been considered as dynamic aspects resulting in uplift and denudation (i.e. Gallagher and Brown, 1999; Japsen et al., 2006). Tectonic inversion of the rifted margins is probably the most important aspect generating uplift at passive margins but this aspect requires a kinematic reorganization at the plate tectonics scale that may result in ubiquitous uplift (see Pedoja et al., 2011). During the Cenozoic, changes in plate tectonics, in particular the disappearance of the Tethys and Farallon slab, the anchoring of the Nazca slab in the deep mantle (Husson et al., 2012) and the Alpine collision, increased the overall compression in the lithosphere, which in turn could have triggered deformation and uplift not only at both active and passive margins (Yamato et al., 2013).

The mean value that we derive here $(\sim 0.06 \mathrm{~mm} / \mathrm{yr})$ is half that previously reported by Pedoja et al., $2011(0.13 \mathrm{~mm} / \mathrm{yr}$ on their Fig. 5). In the present paper, we reappraised relevant data. In other words, we first roughly classified the coastal sequences for active plate boundary vs "passive margin" s.l. (Pedoja et al., 2011a). With our new classification, large amounts of data (e.g. in California, Baja California, Southern Mediterranean, etc.) exhibiting generally relatively high elevation for MIS 5e were derived from this category of geodynamical settings, thereby reducing the mean value. The revised mean elevation of the MIS 5e benchmark for passive margins now stands within the eustatic range of former estimates for MIS 5e sea level with respect to the present-day (e.g. Waelbroeck et al., 2002; Siddal et al., 2006; Kopp et al., 2009; Rohling et al., 2009). However, we must keep in mind that the MIS 5e marker is embedded in staircase coastal sequences that, in some cases, began to form during the earlier Cenozoic (e.g. Eocene and Miocene in South Australia and Argentinian Patagonia, Oligocene in Israel). Consequently, such morphologies cannot be explained by a continuous Late Cenozoic regression punctuated by recurrent stillstands in sea level and should not be interpreted straightforwardly (see Kopp et al., 2009). Again, the mean values are only indicative as they represent unevenly sampled coastlines.

As artifacts of slowly to moderately uplifting areas (geodynamic setting PM, HS and Tr on Table 1), the reclaimed lands developed during the Late Cenozoic are significant for the following reasons: 1) the Miocene shoreline in south Australia extends over $4500 \mathrm{~km}$ and is sometimes located 300-350 km inland (see figure 3 in Quigley et al., 2010); 2) the Miocene shoreline in northeastern America is traced over $350 \mathrm{~km}$ through South Carolina, North Carolina and Virginia, and typically found $140 \mathrm{~km}$ inland; 3 ) in Israel, the Miocene shoreline is present over $350 \mathrm{~km}$ of coasts and can be found $50 \mathrm{~km}$ inland; 4) in northern Spain, Miocene shorelines lay over almost $350 \mathrm{~km}$, and are located 3-8 km inland. These examples show the lateral growth of continents during Late Cenozoic times that act to reclaim land overseas. Such a widespread geomorphic record of long lasting uplift (i.e. Miocene and older) represents convincing long-term evidence of the global compression against coastal margins so well exhibited through sequences including the MIS 5e benchmark (Pedoja et al., 2011; Yamato et al., 2013). 
Overall, sequences of strandlines evolved upward from wellidentified paleocoasts during the middle late Pleistocene, towards more diffuse rasas. Lastly, mere uplifted coastal plains, with clearly individualized shoreline angles (besides the uppermost marker) are generally absent during the Neogene and Paleogene (Figs. 2 and 3) (see one rocky-shore exception in Gupta and Allen, 1999). Obviously, the morphological signature vanishes backward in time, and a variety of reasons can be invoked for this phenomenon. The first reason could be that the uppermost, mid-Cenozoic strandlines are caused by any other process than sea-level oscillations. Indeed, tectonic oscillations would sculpt coastlines just as well as Quaternary glacial cycles do.

Although this explanation cannot be excluded, it is unlikely because it requires fast operating shifts in tectonic that are incompatible with the geological time scale of tectonic movements. Moreover for Neogene sequences, erosion could have dampened the signal, which would alter the morphology of older strandlines, and turn them into rasas and/or coastal plains. Again, this explanation cannot be excluded, but it may be difficult to push back the onset of the fast oscillating glacial cycle into the Cenozoic. Instead, we suggest that Middle and Upper Pleistocene strandlines are well identified from one another thanks to the fast oscillating sea level that follows the mid-Brunhes event (Jansen et al., 1986) with a periodicity of 100,000 years, as indicated by the isotopic record (Lisiecki and Raymo, 2005). Earlier than this event, sea-level oscillations were seemingly of smaller amplitudes and faster wavelengths (40,000 yrs cycle). Because (1) sea level highstands were of shorter duration and (2) because the shorter periods and amplitudes more easily promoted the reoccupation of ancient paleocoasts (e.g. terraces), fingerprints are smaller and compound morphologies easily form as rasas. Lastly, there is no indication so far in the isostopic record for oscillating sea level during the early formation of the ice sheets in Antarctica during the Paleogene. Sea level could have then oscillated with a very long ( $1 \mathrm{Ma}$ ) period and small amplitude that only promoted the development of the extremely wide coastal plains as for instance found in Australia hundreds of kilometers inland. In principal, this likely evolution of the ice sheets explains the evolving morphology of strandlines as they age without the need for a selective erosion. In other words, we strongly suggest that the different styles of the stairs as they age in the coastal sequences are fingerprints of the switching frequencies of glacio-eustatic fluctuations rather than the marks of an increasing degradation of those markers caused by erosion (e.g. Anderson et al., 1999).

\section{Places for future refinements}

Our analysis is based on a compilation of data of variable quality that our strategy prevent from being assessed, verified, or improved individually; obviously it would be desirable to discuss each data at the light of their specific dynamic settings. The corollary is that it is unrealistic to use this database to extract single data points. Rather, we emphasize that the multiplicity of data points makes it possible to have regional, or even global analysis. Selective compilations conversely jeopardize such enterprise. Instead, a possibility to improve the reliability of our database would be to take advantage of developed probabilistic interpolations of sea level change (e.g. Choblet et al., 2013); this would allow for better averaging along documented coastlines and for excluding outliers that have no regional relevance.

While compiling the literature reviewed for this project, we found that many Upper Cenozoic geomorphic indicators are qualitatively but not quantitatively described (e.g. dating and/or leveling of the MIS $5 \mathrm{e}$ benchmark, Fig. 21). These zones are concentrated at high latitudes (Antarctic and Northern Russia, Canada and Greenland); Atlantic islands such as Sao Tomé, Tristan da Cunha, Fernando de Norhona, South Georgia, Meredith (Nunn, 1984); Central Africa, West and East. To the west, 4 sites are documented between Sierra Leone (1) and Ghana (3) along a 1500-km-long coastal stretch. Coastal sequences are found on the Ivory coast ( 3 marine terraces up to at least $12 \mathrm{~m}$, Bird, 2010) and Equatorial Guinea (Bird, 2010). To the east an exceptionally long segment of coast exhibits coral reef sequences that stretch more than $100 \mathrm{~km}$ along the Somalian coast with a prominent coral reef terrace at $7.5 \pm 1.5 \mathrm{~m}$ and reach elevations of about $145 \mathrm{~m}$ on some peninsulas (Ras Illigh for example) (Bird, 2010). In the Persian Gulf, welldeveloped sequences are not described (e.g. Kuwait and Baluchistan

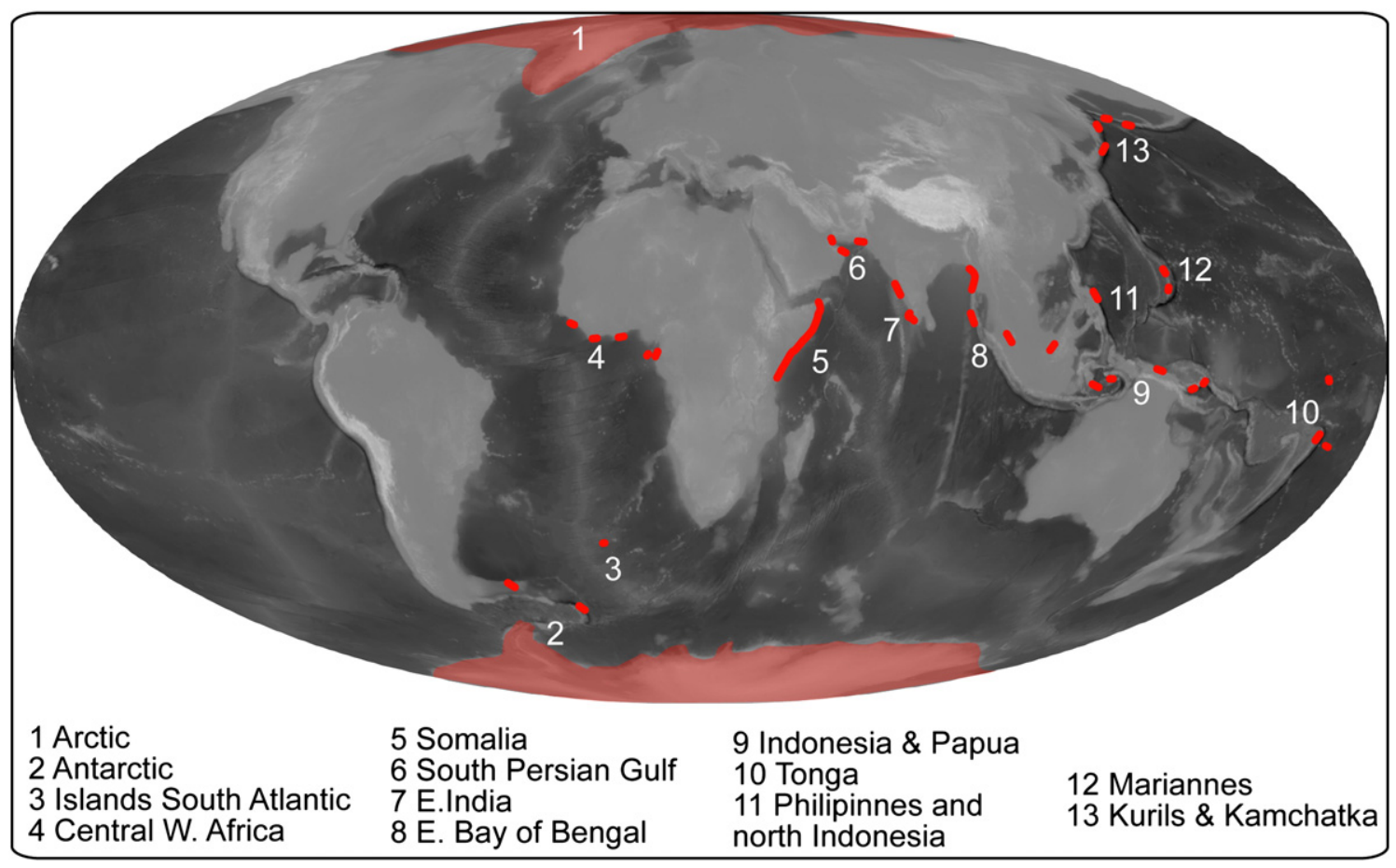

Fig. 21. Major zones (in red) were coastal sequences also are present but poorly described. 
coasts) and on the coasts of India our record is limited both to the west and east. Yet, sequences of paleoshorelines are present along the Bombay-Panjim coast (Sukhtankar, 1995) as well as on the Karnataka and Kerala coasts (Bird, 2010). Quantitative arguments are also lacking in the eastern Bay of Bengal. Sequences are also identified but poorly described on the coast of Burma and the Andaman Islands (Bird, 2010); northern Borneo (both Malaysia and Brunei, as described in Bird, 2010), central Indonesia (personal observation), New Guinea (including the Trobriand, Wollwark and New Britain islands see Ollier, 1975, 1978; Bird, 2010) also represents a vast area lacking precise descriptions of the coastal sequences. The same may be said for the Philippines and more particularly the Sulu archipelago (Voss, 1974) or the Semiraras and Talikud islands (Bird, 2010); some islands of the Marianas and Tonga. The whole coast fronting the northwestern corner of the Pacific plate features coastal sequences that are generally poorly studied, such as the coast of the Kuril Islands (ex Kunashiri Island, Korotky et al., 1995; Pushkar and Razzhigaeva, 2003), Kamchatka (Melekestsev et al., 1974), Chuchotka and Aleutian Islands (Bird, 2010).

\section{Conclusions}

In this review, we compiled the mean rate of uplift for Cenozoic coastal sequences showing staircase geometries and analyzed their conditions of formation and preservation. For sequences where the elevations of MIS 5e strandlines are known (926 sites), we added where available elevations of Holocene (MIS 1, 185 sites), MIS 3 ( 12 sites) and MIS 11 (31 sites) paleocoasts. Furthermore, we included the age and elevation of the uppermost strandline in the sequence where dating from the Early Pleistocene or older (135 "extrapolated" sites and 52 dated sites with Neogene and/or Paleogene shorelines). This allowed us to classify the different geodynamic settings as a function of their associated uplift rates. In increasing uplift rates, the principal results from Table 1 fall into the following categories: Hotspot Chains $(0.01 \pm 0.01 \mathrm{~mm} / \mathrm{yr})$, Passive Margins $(0.06 \pm 0.01 \mathrm{~mm} / \mathrm{yr})$, Rifts $(0.11 \pm 0.01 \mathrm{~mm} / \mathrm{yr})$, Transform faults $(0.25 \pm 0.02 \mathrm{~mm} / \mathrm{yr})$ and Convergent margins, further subdivided into ocean-continent $(0.37 \pm 0.03 \mathrm{~mm} / \mathrm{yr})$, ocean-ocean $(0.42 \pm$ $0.03 \mathrm{~mm} / \mathrm{yr})$, continent-ocean $(0.54 \pm 0.04 \mathrm{~mm} / \mathrm{yr})$, and continentcontinent $(1.47 \pm 0.08 \mathrm{~mm} / \mathrm{yr})$. Finally, we suggest that the formation of compound constructions in coastal sequences has been operational ubiquitously since the Miocene and locally the Eocene. The shaping of "coastal staircases" increased during the Pliocene and Pleistocene as a result of the temporal variability in the frequency and amplitude of glacioeustatic fluctuations. The glacial cycle likely evolved from low-frequency to very low-amplitude oscillations (possibly $>10$ Ma period) during the Paleogene and part of the Neogene, towards faster ( 40,000 yrs period), low amplitude $(\sim 80 \mathrm{~m})$ oscillations during the Pliocene and Early Pleistocene. Since the Middle Pleistocene, oscillations switched to slightly longer (100,000 yrs period), higher amplitude ( $120 \mathrm{~m})$ oscillations. We suggest that the changing staircase morphologies of the world coastlines as they age are fingerprints of the switching frequencies of glacio-eustatic fluctuations on uplifted margins, rather than the marks of an increasing degradation of those markers caused by erosion.

\section{Acknowledgments}

We thank the ANR GiSeLE for funding, and those many individuals who helped KP in collecting relevant references. We are particularly grateful to Philipp Gibbard and two anonymous reviewers for their careful reviews and to Colin D. Woodroffe who corrected mistakes in the southern Pacific data. Real-time updated online version is available at: http://w3.unicaen.fr/recherche/m2c/spip.php?article199.

\section{Appendix A. Supplementary data}

Supplementary data to this article can be found online at http://dx. doi.org/10.1016/j.earscirev.2014.01.007.

\section{References}

Abreu, V.S., Anderson, J.B., 1998. Glacial eustasy during the Cenozoic: sequence stratigraphics implications. Am. Assoc. Pet. Geol. Bull. 82, 1385-1400.

Aharon, P., Chappel, J., 1986. Oxygen isotopes sea level changes and the temperature history of a coral reef environment in New Guinea over the last 100000 years. Palaeogeogr. Palaeoclimatol. Palaeoecol. 56, 337-339.

Alexanderson, H., Landvik, J.Y., Molodkov, A., Murray, A.S., 2011. A multi-method approach to dating middle and late Quaternary high relative sea-level events on NW Svalbard - A case study. Quat. Geochronol. 6, 326-340.

Alvarez-Marrón, J., Hetzel, R., Niedermann, S., Menéndez, R., Marquínez, J., 2008. Origin, structure and exposure history of a wave-cut platform more than $1 \mathrm{Ma}$ in age at the coast of northern Spain: a multiple cosmogenic nuclide approach. Geomorphology 93, 316-334.

Anderson, R.S., Densmore, A.L., Ellis, M.A., 1999. The generation and degradation of marine terraces. Basin Res. 11, 7-19.

Azevedo, J.M.M., Portugal Ferreira, M.R., 1999. Volcanic gaps and subaerial records of palaeo-sea-levels on Flores Island (Azores): tectonic and morphological implications. Geodynamics 28, 117-129.

Bard, E., Jouannic, C., Hamelin, B., Pirazzoli, P.A., Arnold, M., Faure, G., Sumosusastro, P.A., Syaefudin, 1996. Pleistocene sea levels and tectonic uplift based on dating of corals from Sumba Island, Indonesia. Geophys. Res. Lett. 23, 1473-1476.

Bartek, L.R., Vail, P.R., Anderson, J.B., Emmet, P.A., Wu, S., 1991. Effect of Cenozoic ice sheet fluctuations in Antarctica on the stratigraphic signature of the Neogene. J. Geophys. Res. 96, 6753-6778.

Bates, M.R., Parfitt, S.A., Roberts, M.B., 1997. The chronology, palaeogeography and archaeological significance of the marine quaternary record of the West Sussex coastal plain, Southern England, U.K. Quat. Sci. Rev. 16, 1227-1252.

Bates, M.R., Keen, D.H., Lautridou, J.P., 2003. Pleistocene marine and periglacial deposits of the English Channel. J. Quat. Sci. 18, 319-337.

Bekaroglu, E., 2012. Comment on MIS 5a and MIS 3 relatively high sea-level stands on the Hatay-Samanda coast, Eastern Mediterranean, Turkey. U. Dogan, A. Kocyigit, B. Varol, Ä. Ozer, A. Molodkov, E. Zohra. Quaternary International West African Paleoecology and Human Responses: West African Quaternary Research Association (WAQUA), vol. $26280-83$.

Berger, A., Loutre, M.F., 2002. An exceptionally long interglacial ahead? Science 297, $1287-1288$

Berryman, K., 1992. A stratigraphic age of Rotoehu Ash and late Pleistocene climate interpretation based on marine terrace chronology, Mahia Peninsula, North Island, New Zealand. N. Z. J. Geol. Geophys. 35, 1-7.

Berryman, K., 1993a. Distribution, age, and deformation of the late Pleistocene marine terraces at Mahia Peninsula, Hikurangi subduction margin, New Zealand. Tectonics $12,1365-1379$.

Berryman, K., 1993b. Age, Height, and deformation of Holocene marine terraces at Mahia Peninsula, Hikurangi subduction margin, New Zealand. Tectonics 12, 1347-1364.

Bintanja, R., van de Wal, R.S.W., 2008. North American ice sheet dynamics and the onset of 100,000-year glacial cycles. Nature 454, 454. http://dx.doi.org/10.1038/ nature0718.

Bird, E. (Ed.), 2010. Encyclopedia of the World's coastal landforms, vol. 1. Springer, Dordrecht Heidelberg London New York (1493 pp.).

Bloom, A.L., Broecker, W.S., Chappell, J.M.A., Matthews, R.K., Mesolella, K.J., 1974. Quaternary sea level fluctuations on a tectonic coast: $\mathrm{New}^{230} \mathrm{Th} /{ }^{234} \mathrm{U}$ dates from the Huon Peninsula, New Guinea. Quat. Res. 4, 185-205.

Boekschoten, G.J., Best, M.B., Oosterbaan, A., Molenkamp, F.M., 1989. Past corals and recent reefs in Indonesia. Neth. J. Sea Res. 23, 117-122.

Bookhagen, B., Echtler, H.P., Melnick, D., Strecker, M.R., Spencer, J.Q.G., 2006. Using uplifted Holocene beach berms for paleoseismic analysis on the Santa Maria Island, south-central Chile. Geophys. Res. Lett. 33, L15302.1-L15302.5.

Boulila, S., Galbrun, B., Miller, K.G., Pekar, S.F., Browning, J.V., Laskar, J., Wright, J.D., 2011. On the origin of Cenozoic and Mesozoic "third-order" eustatic sequences. Earth Sci. Rev. 109, 94-112.

Bowen, D.Q., 2010. Sea level $\sim 400,000$ years ago (MIS 11) : analogue for present and future sea-level? Clim. Past 6, 19-29.

Brebion, P., Ortlieb, L. 1976. Nouvelles recherches géologiques et malacologiques sur le Quaternaire de la province de Tarfaya (Maroc méridional). Geobios 9, 529-550.

Briggs, R.W., Sieh, K., Amidon, W.H., Galetzka, J., Prayudi, D., Suprihanto, I., Sastra, N., Suwargadi, B., Natawidjaja, D., Farr, T.G., 2008. Persistent elastic behavior above a megathrust rupture patch: Nias island, West Sumatra. J. Geophys. Res. Solid Earth 113, B12406.

Bull, W.B., 1985. Correlation of flights of global marine terraces. 15 th Annual Geomorphology Symposium, pp. 129-152.

Bull, W.B., Cooper, A.F., 1986. Uplifted marine terraces along the Alpine Fault, New Zealand. Science 234, 1125-1228.

Bull, W.B., Cooper, A.F., 1988. Response: New Zealand Marine Terraces: uplift rates. Science 240, 804-805.

Cabioch, G., Ayliffe, L.K., 2001. Raised coral terraces at Malakula, Vanuatu, Southwest Pacific, indicate high sea level during marine isotope stage 3. Quat. Res. 56, 357-365.

Carobene, L., Cevasco, A., 2011. A large scale lateral spreading, its genesis and Quaternary evolution in the coastal sector between Cogoleto and Varazze (Liguria-Italy). Geomorphology 129, 398-411.

Chabli, A., Galindo-Zaldivar, J., Akil, M., Marin-Lechado, C., Chalouan, A., Ruano, P. Bargach, K., Sanz de Galdeano, C. , 2005. Déformations néotectonique dans les dépôts plio-quaternaires de la région de Casablanca - Mohammedia (Meseta côtière, Maroc). Revista de la Sociedad Geologica de España 18, 169-178.

Chappell, J., 1974. Geology of Coral Terraces, Huon Peninsula, New Guinea: a study of Quaternary Tectonic Movements and Sea Level Changes. Geol. Soc. Am. Bull. 85, 553-570. 
Chappell, J., 2002. Sea level changes forced ice breakouts in the Last Glacial cycle: new results from coral terraces. Quat. Sci. Rev. 21, 1229-1240.

Chappell, J., Veeh, H.H., 1978. Late Quaternary tectonic movements and sea-level changes at Timor and Atauro Island. Geol. Soc. Am. Bull. 89, 356-367.

Chappell, J., Omura, A., Esat, T., McCulloch, M., Pandolfi, J., Ota, Y., Pillans, B., 1996. Reconciliation of late Quaternary sea levels derived from coral terraces at Huon Peninsula with deep sea oxygen isotope records. Earth Planet. Sci. Lett. 141, 227-236.

Choblet, G., Husson, L., Bodin, T., 2013. Probabilistic surface reconstruction of relative sealevel during the twentieth century. AGU Fall meeting, San Francisco.

Cisternas, M., Atwater, B.F., Torrejon, F., Sawai, Y., Machuca, G., Lagos, M., Eipert, A Youlton, C., Salgado, L., Kamataki, T., Shishikura, M., Rajendran, C.P., Malik, J.K., Rizal, Y., Husni, M., 2005. Predecessors of the giant 1960 Chile earthquake. Nature 437, 404-407.

Conrad, C.P., 2013. The solid earth's influence on sea level. Geol. Soc. Am. Bull. 125, 1027-1052. http://dx.doi.org/10.1130/B30764.1.

Copeland, L., 2003. The Tayacian of the Cordon Littoral, Ras Beirut (Lebanon) and its relations with other Tayacian sites in the Levant. Paléorient 29, 87-107.

Coque, R., Jauzein, A., 1965. Le Quaternaire moyen de l'Afrique du Nord. Bulletin de l'Association Francaise pour l'Etude du Quaternaire 2, 117-132.

Coutard, S., Lautridou, J.-P., Rhodes, E., Clet, M., 2006. Tectonic, eustatic and climatic significance of raised beaches of Val de Saire, Cotentin, Normandy, France. Quat. Sci. Rev. 25, 595-611.

Darwin, C.R, 1846. Geological observations on South America. Being the third part of the geology of the voyage of the Beagle, under the command of Capt. Fitzroy, R.N. during the years 1832 to 1836. Smith Elder and Co., London (279 pp.)

Dawson, A.G., Dawson, S., Cooper, A.G., Gemmell, A., Bates, R., 2013. A Pliocene age and origin for the strandflat of the Western Isles of Scotland: a speculative hypothesis. Geol. Mag. 150, 360-366.

DeConto, R.M., Pollard, D., 2003. Rapid Cenozoic glaciation of Antarctica induced by declining atmospheric CO2. 421, 245-249.

del Rio, C.J., Griffin, M., McArthur, J.M., Martinez, S., Thirlwall, M.F., 2013. Evidence for early Pliocene and late Miocene transgressions in southern Patagonia (Argentina): $87 \mathrm{Sr} / 86 \mathrm{Sr}$ ages of the pectinid "Chlamys" actinodes (Sowerby). J. S. Am. Earth Sci. 47, 220-229.

Dogan, U., Kocyigit, A., Varol, B., Ozer, A., Molodkov, A., Zohra, E., 2012a. Reply to the comment by Erdem Bekaroglu on "MIS 5a and MIS 3 relatively high sea-level stands on the Hatay-Samanda Coast, Eastern Mediterranean, Turkey. Quaternary International West African Paleoecology and Human Responses: West African Quaternary Research Association (WAQUA), vol. 262 84-87.

Dogan, U., Kocyigit, A., Varol, B., Ozer, Ä.s., Molodkov, A., Zohra, E., 2012b. MIS 5a and MIS 3 relatively high sea-level stands on the Hatayâ-Samanday Coast, Eastern Mediterranean, Turkey. Quaternary International West African Paleoecology and Human Responses: West African Quaternary Research Association (WAQUA), vol. 262 65-79.

Dutton, A., Bard, E., Antonioli, F., Esat, T.M., Lambeck, K., McCulloch, M.T., 2009. Phasing and amplitude of sea-level and climate change during the penultimate interglacial. Nat. Geosci. 2, 355-359.

Duvall, A., Kirby, E., Burbank, D., 2004. Tectonic and lithologic controls on bedrock channe profiles and processes in coastal California. J. Geophys. Res. F: Earth Surf. 109, F03002.

El Asmar, H.M., 1997. Quaternary isotope stratigraphy and paleoclimate of coral ree terraces, Gulf of Aqaba, South Sinai, Egypt. Quat. Sci. Rev. 16, 911-924.

Fleisch, H., Sanlaville, P., 1974. La plage de $+52 \mathrm{~m}$ et son Acheuléen à Ras Beyrouth et à l'Ouadi Aabet (Liban). Paléorient 2, 45-85.

Franceschini, G., Compton, J.S., 2004. Aeolian and marine deposits of the Tabakbaai Quarry area, western Cape, South Africa. S. Afr. J. Geol. 107, 619-632.

Gabert, P., Dolfus, O., Laharie, R., 1970. Les problèmes morphologiques du piémont désertique des Andes péruviennes méridionales. Rev. Géogr. Alp. 58, 265-300.

Galipaud, J.-C., Pineda, R., 1998. Archaeological evidence of differential uplift of Malo (Vanuatu) during the Late Holocene. C. R. Acad. Sci. Paris 327, 777-779.

Gallagher, K., Brown, R., 1999. Denudation and uplift at passive margins: the record on the Atlantic Margin of southern Africa. Philos. Trans. R. Soc. London, Ser. A 357, 835-859. http://dx.doi.org/10.1098/rsta.1999.0354.

Goy, J.L., Macharé, J., Ortlieb, L., Zazo, C., 1992. Quaternary shorelines in southern Peru: A record of global sea-level fluctuations and tectonic uplift in Chala Bay. Quat. Int 15-16, 99-112.

Gradstein, F.M., Ogg, J.G., Schmitz, M.D., Ogg, G.M. (Eds.), 2012. The Geological Time Scale, vol. 2. Elsevier, Amsterdam, Boston, Heidelberg, London, New York, Oxford, Paris, San Diego, San Francisco, Singapore, Sydney, Tokyo (Volume set: 1176 pp.).

Guilcher, A., 1974. Les "rasas»: un problème de morphologie littorale générale. Ann. Geophys. 83, 1-33.

Guilcher, A., Bodéré, J.-C., Coudé, A., Hansom, J.D., Moign, A., Peulvast, J.-P., 1986. Le problème des strandflats en cinq pays de hautes latitudes. Rev. Géol. Dynam. Géog. Phys. 27, 47-79

Gupta, S., Allen, P.A., 1999. Fossil shore platforms and drowned gravel beaches: evidence for high-frequency sea-level fluctuations in the distal alpine foreland basin. J. Sediment. Res. 69, 394-413.

Guyomard, T.S., Aïssaoui, D.M., McNeill, D.F., 1996. Magnetostratigraphic dating of the uplifted atoll of Maré: Geodynamics of the Loyalty Ridge, SW Pacific. J. Geophys. Res. 101, 601-612.

Gvirtzman, G., Kronfeld, J., Buchbinder, B., 1992. Dated coral reefs of southern Sinai (Red Sea) and their implication to late Quaternary sea levels. Mar. Geol. 108, 29-37.

Gvirtzman, Z., Steinberg, J., Bar, O., Buchbinder, B., Zilberman, E., Siman-Tov, R., Calvo, R. Grossowicz, L., Almogi-Labin, A., Rosensaft, M., 2011. Retreating Late Tertiary shorelines in Israel: implications for the exposure of north Arabia and Levant during Neotethys closure. Lithosphere 3, 95-109.
Hampton, C., 2000. Deformation of the Western Edge of the North American Plate in Proximity to the San Andreas Fault in North-Central California as Recorded in Late Quaternary Marine Terraces. (Senior thesis) Trinity, San Antonio (31 pp.).

Hartley, A.J., May, G., Chong, G., Turner, P., Kape, S.J., Jolley, E.J., 2000. Development of a continental forearc: A Cenozoic example from the Central Andes, northern Chile. Geology 28, 331-334.

Hearty, P.J., 2002. Revision of the late Pleistocene stratigraphy of Bermuda. Sediment. Geol. 153, 1-21.

Hearty, P.J., Neumann, A.C., 2001. Rapid sea level and climate change at the close of the Last Interglaciation (MIS 5e): evidence from the Bahama Islands. Quat. Sci. Rev. 20, 1881-1895.

Hearty, P.J., Hollin, J.T., Neumann, A.C., O'Leary, M.J., McCulloch, M., 2007. Globa sea-level fluctuations during the Last Interglaciation (MIS 5e). Quat. Sci. Rev. 26 2090-2112.

Hoang, C.T., Ortlieb, L., Weisrock, A., 1978. Nouvelles datations 230Th/234U de terrasses marines "ouljiennes" du sud-ouest du Maroc et leurs significations stratégique et tectonique. Comptes-Rendus de l'Académie des Sciences: série D 286, 1759-1762.

Holbourn, A., Kuhnt, W., Simo, J.A.T., Li, Q., 2004. Middle Miocene isotope stratigraphy and paleoceanographic evolution of the northwest and southwest Australian margin (Wombat Plateau and Great Australian Bight). Palaeogeogr. Palaeoclimatol. Palaeoecol. 208, 1-22.

Houston, J., Hart, D., Houston, A., 2008. Neogene sedimentary deformation in the Chilean forearc and implications for Andean basin development, seismicity and uplift. J. Geol. Soc. Lond. 165, 291-306.

Husson, L., Conrad, C.P., Faccenna, C., 2012. Plate motions, Andean orogeny, and volcanism above the South Atlantic convection cell. Earth Planet. Sci. Lett. 317-318, 126-135. http://dx.doi.org/10.1016/j.epsl.2011.11.040.

Ikeda, S., Kasuya, M., Ikeya, M., 1991. ESR ages of middle Pleistocene corals from the Ryukyu Islands. Quat. Res. 36, 61-71.

Ikeya, M., Ohmura, K., 1983. Comparison of ESR ages of corals from marine terraces with $14 \mathrm{C}$ and $230 \mathrm{Th} / 234 \mathrm{U}$ ages. Earth Planet. Sci. Lett. 65, 34-38.

Imbrie, J., Hays, J.D., Martinson, D.G., McIntyren, A., Mix, A.L., Morley, J.J., Pisias, N.G., Prell, W., Shackleton, N.J., 1984. The orbital theory of Pleistocene climate: Support from revised chronology of the marine 180 record. In: Berger, A., et al. (Eds.), Milankovitch and climate. Reidel, Dordrecht, Netherlands, pp. 269-305.

Inagaki, M., Omura, A., 2006. Uranium-series Age of the Highest Marine Terrace of the Upper Pleistocene on Kikai Island, Central Ryukyus, Japan. Quat. Res. 45, 41-48.

Inman, D.L., Nordstrom, C.E., 1971. On the tectonic and morphologic classification of coasts. J. Geol. 79, 1-21.

Issar, A., Picard, L., 1969. Sur le Tyrrhénien des côtes d'Israël et du Liban. Bull. Assoc. Fr. Etud. Quatern. 6, 35-41.

James, N.P., Mountjoy, E.W., Omura, A., 1971. An early Wisconsin reef Terrace at Barbados, West Indies, and its climatic implications. Geol. Soc. Am. Bull. 82, 2011-2018.

Jankaew, K., Atwater, B.F., Sawai, Y., Choowong, M., Charoentitirat, T., Martin, M.E., Prendergast, A., 2008. Medieval forewarning of the 2004 Indian Ocean tsunami in Thailand. 455, 1228-1231.

Jansen, J.H.F., Kuijpers, A., Troelstra, S.R., 1986. A mid-Brunhes climatic event: long-term changes in atmosphere and ocean circulation. Science 232, 619-622 ( $\left.{ }^{\circ} 4750\right)$.

Japsen, P., Bonow, J., Green, P., Chalmers, J., Lidmar-Bergström, K., 2006. Elevated, passive continental margins: Long-term highs or Neogene uplifts? New evidence from West Greenland. Earth Planet. Sci. Lett. 248, 330-339.

Jardine, W.G., 1981. The determination of former shoreline positions in areas of large tidal range, with examples taken mainly from Scotland. Bull. Assoc. Fr. Etud. Quatern. 18 $67-70$.

John, C.M., Karner, G.D., Browning, E., Leckie, R.M., Mateo, Z., Carson, B., Lowery, C., 2011 Timing and magnitude of Miocene eustasy derived from the mixed siliciclasticcarbonate stratigraphic record of the northeastern Australian margin. Earth Planet. Sci. Lett. 304, 455-467.

Johnson, M.E., Baarli, B.G., 2012. Development of Intertidal Biotas Through Phanerozoic Time. In: Talent, J.D. (Ed.), Earth and Life SE-5: International Year of Planet Earth. Springer, Netherlands DA, pp. 63-128 (2012/01/01).

Johnson, M.E., Libbey, L.K., 1997. Global review of Upper Pleistocene (Substage 5e) Rocky Shores: tectonic segregation, substrate variation and biological diversity. J. Coast. Res. 13, 297-307.

Johnson, M.E., Baarli, B.G., Santos, A., Mayoral, E., 2011. Ichnofacies and microbial buildups on Late Miocene rocky shores from Menorca (Balearic Islands), Spain. Facies $57,255-265$.

Jouannic, C., Taylor, F.W., Bloom, A.L., Bernat, M., 1980. Late Quaternary uplift, from emerged reef terraces of Santo and Malekula islands, central New Hebrides island arc. Un Escap, CCOP/SOPAC. Technical Bulletin, vol. 3, pp. 91-108.

Jouannic, C., Taylor, F.W., Bloom, A.L., 1982. Sur la surrection et la déformation d'un arc jeune. l'arc des Nouvelles Hébrides: Travaux et documents ORSTOM, vol. 147 223-246.

Keskin, S., Pedoja, K., Bektas, O., 2011. Coastal Uplift along the Eastern Black Sea Coast: New Marine Terrace Data from Eastern Pontides, Trabzon (Turkey) and a Review. J. Coast. Res. 27, 63-73.

Konishi, K., Schlanger, S.O., Omura, A., 1970. Neotectonic rates in the central Ryukyu Islands derived from 230Th coral ages. Mar. Geol. 9, 225-240.

Kopp, R.E., Simons, F.J., Mitrovica, J.X., Maloof, A.C., Oppenheimer, M., 2009. Probabilistic assessment of sea level during the last interglacial stage. Nature 462, 863-867.

Korotky, A.M., Razjigaeva, N.G., Grebennikova, T.A., Ganzey, L.A., Mokhova, L.M., Bazarova, V.B., Sulerzhitsky, L.D., 1995. Holocene marine terraces of Kunashiri Island, Kurile Islands. Quat. Res. 34, 359-375.

Lajoie, K.R., 1986. Coastal Tectonics. In: Press, N.A. (Ed.), Active tectonic. National Academic Press, Washington D.C., pp. 95-124.

Lajoie, K.R., Ponti, D.J., Powell, C.L., Mathieson, A.M., Sarna- Wojcicki, A.M., 1991. Emergent marine strandlines and associated sediments, coastal California: a record of 
Quaternary sea-level fluctuations, vertical tectonic movements, climatic changes, and coastal processes. In: Morrison (Ed.), Quaternary Nonglacial Geology: Conterminous U.S.: The Geology of North America, v. K-2: Geological Society of America, Boulder, Colorado, pp. 190-214

Lay, T., Kanamori, H., Ammon, C.J., Koper, K.D., Hutko, A.R., Ye, L., Yue, H., Rushing, T.M., 2012. Depth-varying rupture properties of subduction zone megathrust faults. J. Geophys. Res. Solid Earth 117, B04311.

Lefêvre, D., Raynal, J.-P., 2002. The plio-pleistocene formations of Casablanca and the marine Quaternary chronostratigraphy of Morocco revisited. Quaternaire 13, 9-21.

Lisiecki, L.E., Raymo, M.E., 2005. A Pliocene-Pleistocene stack of 57 globally distributed benthic delta 180 records. Paleoceanography 20, PA1003.

Ludwig, K.R., Muhs, D.R., Simmons, K.R., Moore, J.G., 1992. Sr-Isotope record of Quaternary marine terraces on the California coast and off Hawaii. Quaternary Research 37, 267-280.

Maejima, Y., Matsuzaki, H., Higashi, T., 2005. Application of cosmogenic 10Be to dating soils on the raised coral reef terraces of Kikai Island, southwest Japan. Geoderma 126, 389-399.

Maouche, S., Meghraoui, M., Morhange, C., Belabbes, S., Bouhadad, Y., Haddoum, H., 2011. Active coastal thrusting and folding, and uplift rate of the Sahel Anticline and Zemmouri earthquake area (Tell Atlas, Algeria). Tectonophysics 509, 69-80.

Maouche, S., Meghraoui, M., Morhange, C., Belabbes, S., Bouhadad, Y., Haddoum, H., 2013. Reply to the comment of Pedoja et al. by Maouche, S., Meghraoui, M., Morhange, C., Belabbes, S., Bouhadad, Y. and Haddoum, H. on the published paper: Maouche, S., Meghraoui, M., Morhange, C., Belabbes, S., Bouhadad, Y. and Haddoum, H., 2011, Active coastal thrusting and folding, and uplift rate of the Sahel anticline and Zemmouri earthquake area (Tell Atlas, Algeria), Tectonophysics, 509 (2011) 69-80. Tectonophysics 601, 245-247.

Martin, J.M., Braga, J.C., Betzler, C., 2003. Late Neogene - Recent uplift of the Cabo de Gata volcanic province, Almeria, SE Spain. Geomorphology 50, 27-42.

Martinson, D.G., Pisias, N.G., Hays, J.D., Imbrie, J., Moore, T.C., Shackleton, N.J., 1987. Age dating and the orbital theory of the ice ages: Development of a high-resolution 0 to 300,000-year chronostratigraphy. Quat. Res. 27, 1-29.

Mary, G., 1983. Evolucion del margen costero de la cordillera Cantabrica en Asturias desde el Mioceno. Trab. Geol. Univ. Oviedo 13, 3-35.

Masuda, F., 2007. Paleoclimate of Interglacial Marine Isotope stage 11 (MIS 11) from strata in the Japanese Islands. Quat. Res. 46, 235-240.

McSaveney, M.J., Graham, I.J., Begg, J.G., Beu, A.G., Kim, K., Zondervan, A., 2006. Late Holocene uplift of beach ridges at Turakirae Head, south Wellington coast, New Zealand. N. Z. J. Geol. Geophys. 49, 337-358.

Meco, J., Guillou, H., Carrecedo, J.C., Lomoschitz, A., Ramos, A.-J.G., Rodriguez-Yanez, J.-J., 2002. The maximum warmings of the Pleistocene world climate recorded in the Canary Islands. Palaeogeogr. Palaeoclimatol. Palaeoecol. 185, 197-210.

Meco, J., Scaillet, S., Guillou, H., Lomoschitz, A., Carlos Carracedo, J., Ballester, J., Betancort, J.-F., Cilleros, A., 2007. Evidence for long-term uplift on the Canary Islands from emergent Mio-Pliocene littoral deposits. Glob. Planet. Chang. 57, 222-234.

Melekestsev, I.V., Braitseva, O.A., Erlikh, E.N., Shantser, A.E., Chelebaeva, A.I., Lupikina, E.G., Egorova, I.A., Kozhemvaka, N.N., 1974. Kamchatka, Kurile and Komander Islands. History of development of relief of Siberia and Far East: Moscow.

Melnick, D., Bookhagen, B., Echtler, H., Strecker, M.R., 2006. Coastal deformation and great subduction earthquakes, Isla Santa María, Chile ( $\left.37^{\circ} \mathrm{S}\right)$. Geol. Soc. Am. Bull. 118, $1463-1480$.

Melnick, D., Cisternas, M., Moreno, M., Norambuena, R., 2012. Estimating coseismic coastal uplift with an intertidal mussel: calibration for the 2010 Maule Chile earthquake $(\mathrm{Mw}=8.8)$. Quat. Sci. Rev. 42, 29-42.

Merritts, D., Vincent, K.R., 1989. Geomorphic response of coastal streams to low, intermediate, and high rates of uplift, Mendocino Triple Junction region, Northern California. Geol. Soc. Am. Bull. 110, 1373-1388.

Milne, G.A., Long, A.J., Bassett, S.E., 2005. Modelling Holocene relative sea-level observations from the Caribbean and South America. Quat. Sci. Rev. 24, 1183-1202.

Morell, K.D., Fisher, D.M., Gardner, T.W., La Femina, P., Davidson, D., Teletzke, A., 2011. Quaternary outer fore-arc deformation and uplift inboard of the Panama Triple Junction, Burica Peninsula. J. Geophys. Res. Solid Earth 116 (n/a).

Muhs, D.R., 2001. Evolution of Soils on Quaternary Reef Terraces of Barbados, West Indies. Quat. Res. 56, 66-78.

Muhs, D.R., Rockwell, T.K., Kennedy, G.L., 1992. Late quaternary uplift rates of marine terraces on the Pacific coast of North America, southern Oregon to Baja California sur. Quaternary International 15-16, 121-133.

Muhs, D.R., Simmons, K.R., Kennedy, G.L., Rockwell, T.K., 2002a. The last interglacial period on the Pacific Coast of North America: Timing and paleoclimate. Geol. Soc. Am. Bull. 114, 569-592.

Muhs, D.R., Simmons, K.R., Steinke, B., 2002b. Timing and warmth of the Last Interglacial period: new U-series evidence from Hawaii and Bermuda and a new fossil compilation for North America. Quat. Sci. Rev. 21, 1355-1383.

Nir, D., 1971. Marine Terraces of Southern Sinai. Geogr. Rev. 61, 32-50.

Nunn, P.D., 1984. Evidence For Late Quaternary Sea-Level Change Around St-Helena Island, South-Atlantic. Catena 11, 187-195.

Occhietti, S., Raynal, J.-P., Pichet, P., Lefèvre, D., 2002. Aminostratigraphie des formations littorales Pléistocènes et Holocènes de la région de Casablanca. Maroc: Quaternaire 13, 55-64.

Ollier, C.D., 1975. Coral Island Geomorphology - the Trobriand Islands. Z. Geomorphol. 19, 164-190.

Ollier, C.D., 1978. Geomorphology and tectonics of Woodlark Island, Papua New Guinea. Z. Geomorphol. 22, 1-20.

Orme, A.R., 1988. Quaternary tectonism along the Pacific coast of the Californias: a contrast in style. In: Stewart, S., Vita-Finzi, C. (Eds.), Coastal Tectonics, v. 146: Geological Society Special Publications, London, pp. 179-197.
Ortlieb, L., 1975. Recherches sur les formations Plio-Quaternaires du littoral ouestsaharien ( $20^{\circ} 30^{\prime}-20^{\circ} 40^{\prime}$ lat. N): Travaux et Documents de l'ORSTOM, v. 48, 284

Ota, Y., 1986. Marine terraces as reference surfaces in late Quaternary tectonics studies: examples from the Pacific Rim. R. Soc. N. Z. 24, 357-375.

Ota, Y., Omura, A., 1992. Contrasting styles and rates of tectonic uplift of coral reef terraces in the Ryukyu and Daito Islands, Southwestern Japan. Quat. Int. 15/16, 17-29.

Ota, Y., Yamaguchi, M., 2004. Holocene coastal uplift in the Western Pacific Rim in the context of the Late Quaternary uplift. Quat. Int. 120, 105-117.

Paine, M.D., Bennets, D.A., Webb, J.A., Morand, V.J., 2004. Nature and extent of Pliocene strandlines in southwestern Victoria and their application to Late Neogene tectonics. Aust. J. Earth Sci. 51, 407-422.

Paulson, A., Zhong, S., Wahr, J., 2005. Modelling post-glacial rebound with lateral viscosity variations. Geophys. J. Int. 163, 357-371.

Pedoja, K., Dumont, J.F., Lamothe, M., Ortlieb, L., Collot, J.-Y., Ghaleb, B., Auclair, M., Alvarez, V., Labrousse, B., 2006a. Plio-Quaternary uplift of the Manta Peninsula and La Plata Island and the subduction of the Carnegie Ridge, central coast of Ecuador. J. S. Am. Earth Sci. 22, 1-21.

Pedoja, K., Ortlieb, L., Dumont, J.F., Lamothe, M., Ghaleb, B., Auclair, M., Labrousse, B., 2006b. Quaternary coastal uplift along the Talara Arc (Ecuador, Northern Peru) from new marine terrace data. Mar. Geol. 228, 73-91.

Pedoja, K., Bourgeois, J., Pinegina, T., Higman, B., 2006c. Does Kamchatka belong to North America? An extruding Okhotsk block suggested by coastal neotectonics of the Ozernoi Peninsula, Kamchatka, Russia. Geology 34, 353-356.

Pedoja, K., Dumont, J.F., Ortlieb, L., 2009. Levantamiento Cuaternario costero del Arco de Talara (Ecuador y norte del Perú): cuantificaciones con las secuencias de terrazas marina. In: Collot, J.-Y., Sallares, V., Pazmiño, N. (Eds.), Geologia y Geofisica marina y terrestre del Ecuador desde la costa continental hasta las islas Galapagos. Comisión Nacional del Derecho del Mar (CNDM), Institut de Recherche pour le Développement (IRD), Instituto Oceanográfico de la Armada (INOCAR), Guayaquil, pp. 107-129.

Pedoja, K., Husson, L., Regard, V., Cobbold, P.R., Ostanciaux, E., Johnson, M.E., Kershaw, S., Saillard, M., Martinod, J., Furgerot, L., Weill, P., Delcaillau, B., 2011a. Relative sea-level fall since the last interglacial stage: Are coasts uplifting worldwide? Earth Sci. Rev. $108,1-15$.

Pedoja, K., Regard, V., Husson, L., Martinod, J., Guillaume, B., Fucks, E., Iglesias, M., Weill, P., 2011b. Uplift of Quaternary shorelines in Eastern Patagonia: Darwin revisited. Geomorphology 127 (2011b), 121-142.

Pedoja, K., Authemayou, C., Pinegina, T., Bourgeois, J., Nexer, M., Delcaillau, B., Regard, V., 2013a. Arc-continent collision of the Aleutian-Komandorsky arc into Kamchatka: insight into Quaternary tectonic segmentation through Pleistocene marine terraces and morphometric analysis of fluvial drainage. Tectonics 32, 827-842. http://dx.doi.org/ 10.1002/tect.20051,2013.

Pedoja, K., Djellit, H., Authemayou, C., Deverchere, J., Strzerzynski, P., Heddar, A., Nexer, M., Boudiaf, A., 2013b. Comment on: Active coastal thrusting and folding, and uplift rate of the Sahel Anticline and Zemmouri earthquake area (Tell Atlas, Algeria), by S. Maouche, M. Meghraoui, C. Morhange, S. Belabbes, y. Bouhadad, H. Haddoum. [Tectonophysics, 2011, 509, 69-80]. Tectonophysics 601, 236-244.

Peltier, W.R., 2004. Global glacial isostasy and the surface of the ice-age earth: The ICE-5G (VM2) Model and GRACE. Annu. Rev. Earth Planet. Sci. 32, 111-149.

Pickard, J., Adamson, D.A., Harwood, D.M., Miller, G.H., Quilty, P.G., Dell, R.K., 1988. Early Pliocene marine sediments, coastline, and climate of East Antarctica. Geology 16, 158-161.

Pickett, J.W., Ku, T.L., Thompson, C.H., Roman, D., Kelley, R.A., Huang, Y.P., 1989. A review of age determinations on Pleistocene corals in Eastern Australia. Quat. Res. 31, 392-395.

Pinegina, T., Kravchunovskaya, E.A., Lander, A.V., Kozhurin, A.I., Bourgeois, J., Martin, E.M., 2010. Holocene vertical movement of Kamchatsky peninsula coast (Kamchatka) based on studies of marine terraces. Bulletin of Kamchatka regional association "Educational-scientific center" Earth Sciences (Vestnik KRAUNTZ Nauki o Zemle), vol. 15 231-247.

Pinegina, T.K., Bourgeois, J., Kravchunovskaya, E.A., Lander, A.V., Arcos, M.E.M., Pedoja, K., MacInnes, B.T., 2013. A nexus of plate interaction: Vertical deformation of Holocene wave-built terraces on the Kamchatsky Peninsula (Kamchatka, Russia). Geol. Soc. Am. Bull. 125, 1554-1568. http://dx.doi.org/10.1130/B30793.1.

Pinter, N.M., Sorlien, C., 1991. Evidence for latest Pleistocene to Holocene movement on the Santa Cruz Island fault, California. Geology 19, 909-912.

Pinter, N.M., Lueddecke, S.B., Keller, E.A., Simmons, K.R., 1998. Late Quaternary slip on the Santa Cruz Island fault, California. Geol. Soc. Am. Bull. 110, 711-722.

Pirazzoli, P.A., 1991. World Atlas of Holocene Sea-Level Changes. Elsevier, Amsterdam (300 pp.).

Pirazzoli, P.A., 1994. Tectonic shorelines. In: Carter, R.W.G., Woodroffe, C.D. (Eds.), Coastal Evolution: Late Quaternary shoreline morphodynamics. Cambridge University Press, Edimburgh, p. 517.

Pirazzoli, P.A., Radtke, U., Hantoro, W.S., Jouannic, C., Hoang, C.T., Causse, C., Best, M.B., 1993. A one million-year-long sequence of marine terraces on Sumba Island, Indonesia. Mar. Geol. 109, 221-236.

Pushkar, V.S., Razzhigaeva, N.G., 2003. The Pliocene-Pleistocene Golovnin Formation of Kunashir Island (The Kuriles): stratigraphy and formation conditions. Stratigr. Geol. Correl. 11, 492-504.

Quigley, C.M., Clark, D., Sandiford, M., 2010. Tectonic geomorphology of Australia. In: Bishop, P., Pillans, B. (Eds.), Australian Landscapes. Special Publication, vol. 346. Geological Society, London, pp. 243-265.

Ramalho, R.S., Helffrich, G., Cosca, M., Vance, D., Hoffmann, D., Schmidt, D.N., 2010. Vertical movements of ocean island volcanoes: insights from a stationary plate environment. Mar. Geol. 275, 84-95.

Raymo, M.E., Mitrovica, J.X., O'Leary, M.J., DeConto, R.M., Hearty, P.J., 2011. Departures from eustasy in Pliocene sea-level records. Nat. Geosci. 4, 328-332. 
Regard, V., Saillard, M., Martinod, J., Audin, L., Carretier, S., Pedoja, K., Riquelme, R Paredes, P., Hérail, G., 2010. Renewed uplift of the Central Andes Forearc revealed by coastal evolution during the Quaternary. Earth Planet. Sci. Lett. 297, 199-210.

Rehak, K., Niedermann, S., Preusser, F., Strecker, M.R., Echtler, H., 2010. Late Pleistocene landscape evolution in south-central Chile constrained by luminescence and stable cosmogenic nuclide dating. Geol. Soc. Am. Bull. 122, 1235-1247.

Rhodes, E.J., Singarayer, J.S., Raynal, J.-P., Westaway, K.E., Sbihi-Alaoui, F.Z., 2006. New age estimates for the Palaeolithic assemblages and Pleistocene succession of Casablanca. Morocco: Quaternary Science Reviews Dating the Quaternary: progress in luminescence dating of sediments 25, 2569-2585.

Roberts, D.L., Matthews, T., Herries, A.I.R., Boulter, C., Scott, L., Dondo, C., Mtembi, P. Browning, C., Smith, R.M.H., Haarhoff, P., Bateman, M.D., 2011. Regional and globa context of the Late Cenozoic Langebaanweg (LBW) palaeontological site: West Coast of South Africa. Earth Sci. Rev. 106, 191-214

Rohling, E.J., Grant, K., Bolshaw, M., Roberts, A.P., Siddall, M., Hemleben, C., Kucera, M., 2009. Antarctic temperature and global sea level closely coupled over the past five glacial cycles. Nat. Geosci. 2, 500-504

Saillard, M., Hall, S.R., Audin, L., Farber, D.L., Hérail, G., Martinod, J., Regard, V., Finkel, R.C. Bondoux, F., 2009. Non-steady long-term uplift rates and Pleistocene marine terrace development along the Andean margin of Chile $\left(31^{\circ} \mathrm{S}\right)$ inferred from $10 \mathrm{Be}$ dating. Earth Planet. Sci. Lett. 277, 50-63.

Sandiford, M., 2007. The tilting continent: A new constraint on the dynamic topographic field from Australia. Earth Planet. Sci. Lett. 261, 152-163.

Santos, A. Mayoral, E. Da Silva, C.M., Cachao, M., Domenech, R, Martinell, J., 2008. Trace fossil assemblages on Miocene rocky shores of Southern Iberia. In: Wisshak, M. Tapanila, L. (Eds.), Current Developments in Bioerosion. Springer, Berlin Heidelberg New York, pp. 431-450.

Santos, A., Mayoral, E., Da Silva, C.M., Cachao, M., Johnson, M.E., Baarli, B.G., 2010. Miocene intertidal zonation on a volcanically active shoreline: Porto Santo in the Madeira Archipelago, Portugal. Lethaia 44, 26-32.

Sasaki, K., Omura, A., Murakami, K., Sagawa, N., Nakamori, T., 2004. Interstadial coral ree terraces and relative sea-level changes during marine oxygen isotope stages 3-4, Kikai Island, central Ryukyus, Japan. Quaternary International Coastal Environmenta Change during Sea-Level Highstands. IGCP 437 Symposium, Barbados, vol. 120, pp. 51-64.

Satake, K., Atwater, B.F., 2007. Long-Term Perspectives on Giant Earthquakes and Tsunamis at Subduction Zones. Annu. Rev. Earth Planet. Sci. 35, 349-374.

Sawai, Y., Namegaya, Y., Okamura, Y., Satake, K., Shishikura, M., 2012. Challenges of anticipating the 2011 Tohoku earthquake and tsunami using coastal geology. Geophys. Res. Lett. 39 L21309.

Siddal, M., Chappell, J., Potter, E.-K., 2006. Eustatic sea level during past interglacials. In: Sirocko, F., Claussen, M., Sanchez Goñi, M.F., Litt, T. (Eds.), The Climate of Past Interglacials. Elsevier, Amsterdam, pp. 75-92.

Sieh, K., Natawidjaja, D.H., Meltzner, A.J., Shen, C.-C., Cheng, H., Li, K.-S., Suwargadi, B.W. Galetzka, J., Philibosian, B., Edwards, R.L., 2008. Earthquake Supercycles Inferred from Sea-Level Changes Recorded in the Corals of West Sumatra. Science 322, 1674-1678

Snyder, N.P., Whipple, K.X., Tucker, G.E., Merritts, D.J., 2000. Landscape response to tectonic forcing: Digital elevation model analysis of stream profiles in the Mendocino triple junction region, northern California. Geol. Soc. Am. Bull. 112, 1250-1263.

Stirling, C.H., Esat, T.M., Lambeck, K., McCulloch, M.T., 1998. Timing and duration of the Last Interglacial: evidence for a restricted interval of widespread coral reef growth. Earth Planet. Sci. Lett. 160, 745-762.

Stocchi, P., Escutia, C., Houben, A.J.P., Vermeersen, B.L.A., Bijl, P.K., Brinkhuis, H., DeConto R.M., Galeotti, S., Passchier, S., Pollard, D., Brinkhuis, H., Escutia, C., Klaus, A., Fehr, A Williams, T., Bendle, J.A.P., Bijl, P.K., Bohaty, S.M., Carr, S.A., Dunbar, R.B., Flores, J.A GonzÃ lez, J.J., Hayden, T.G., Iwai, M., Jimenez-Espejo, F.J., Katsuki, K., Kong, G.S., McKay, R.M., Nakai, M., Olney, M.P., Passchier, S., Pekar, S.F., Pross, J., Riesselman, C., Röhl, U., Sakai, T., Shrivastava, P.K., Stickley, C.E., Sugisaki, S., Tauxe, L., Tuo, S., van de Flierdt, T., Welsh, K., Yamane, M., 2013. Relative sea-level rise around East Antarctica during Oligocene glaciation. Nat. Geosci. 6, 380-384.

Strasser, A., Strohmenger, C., Davaud, E., Bach, A., 1992. Sequential evolution and diagenesis of Pleistocene coral reefs (South Sinai, Egypt). Sediment. Geol. 78, 59-79.

Sukhtankar, R.K., 1995. An evolutionary model based on geomorphologic and tectonic characteristics of the Maharashtra Coast, India. Quat. Int. 26, 131-137.
Szabo, B.J., Vedder, J.G., 1971. Uranium-series dating of some pleistocene marine deposits in southern California. Earth and Planetary Science Letters 11, 283-290.

Taylor, F.W., Isacks, B.L., Jouannic, C., Bloom, A.L., Dubois, J., 1980. Coseismic and Quaternary Vertical Tectonic Movements, Santo and Malekula Islands, New Hebrides Island Arc. J. Geophys. Res. 85, 5367-5381.

Taylor, F.W., Jouannic, C., Gilpin, L., Bloom, A.L., 1982. Coral colonies as monitors of change in relative level of the land and sea: application to vertical tectonism. Proc.4th Int. Coral Reef congress, pp. 485-492.

Taylor, F.W., Jouannic, C., Bloom, A.L., 1985. Quaternary uplift of the Torres Islands, northern New Hebrides frontal arc:comparison with Santo and Malekula Islands, central New Hebrides frontal Arc. J. Geol. 93, 419-438.

Taylor, F.T., Frohlich, C., Lecolle, J., Strecker, M.R., 1987. Analysis of partially emerged corals and reef terraces in the central Vanuatu arc:comparison of contemporary coseismic and nonseismic with Quaternary vertical movements. J. Geophys. Res. 92, 4905-4933.

Texier, J.P., Evin, J., Occhietti, S., Raynal, J.-P., Lefèvre, D., 1994. Upper Pleistocene and Holocene records on the Casablanca coast (Morocco). Quaternaire 5, 173-180.

Texier, J.P., Lefèvre, D., Raynal, J.-P., El Graoui, M., 2002. Lithostratigraphy of the littoral deposits of the last one million years in the Casablanca region (Morocco). Quaternaire $13,23-41$.

van de Plassche, O., 1986. Sea-level research: a manual for the collection and evaluation of data. Geo Books, Norwich, UK (618 pp.).

Vidal, L., Bickert, T., Wefer, G., Röhl, U., 2002. Late Miocene stable isotope stratigraphy of SE Atlantic ODP Site 1085: Relation to Messinian events. Mar. Geol. 180, 71-85.

Voss, F., 1974. Geology and geomorphology of the Sulu Archipelago. Z. Geomorphol. 18, 389-409.

Waelbroeck, C., Labeyrie, L.D., Michel, E., Duplessy, J.C., McManus, J.F., Lambeck, K., Balbon, E., Labracherie, M., 2002. Sea-level and deep water temperature changes derived from benthic foraminifera isotopic records. Ouat. Sci. Rev. 21, 295-305.

Wallace, M.W., Dickinson, J.A., Moore, D.H., Sandiford, M., 2005. Late Neogene strandlines of southern Victoria: a unique record of eustasy and tectonics in southeast Australia. Aust. J. Earth Sci. 52, 279-297.

Wang, K., 2007. Elastic and viscoelastic models of crustal deformation in subduction earthquake cycles. In: Dixon, T.H., Moore, J.C. (Eds.), The Seismogenic Zone of Subduction Thrust Faults. Columbia Press University, pp. 540-575.

Ward, C.M., 1988. New Zealand Marine Terraces: Uplift Rates. Science 240.

Ward, C.M., Valensise, G., 1994. The Palos Verdes terraces. California: Bathtub rings from a buried reverse fault: Journal of Geophysical Research 99, 4485-4494.

Westerhold, T., Bickert, T., Röhl, U., 2005. Middle to late Miocene oxygen isotope stratigraphy of ODP site 1085 (SE Atlantic): new constrains on Miocene climate variability and sea-level fluctuations. Palaeogeogr. Palaeoclimatol. Palaeoecol. 217, 205-222.

Winograd, I.J., Landwehr, J.M., Ludwig, K.R., Coplen, T.B., Riggs, A.C., 1997. Duration and Structure of the Past Four Interglaciations. Quat. Res. 48, 141-154.

Woodroffe, C.D., 2005. Late Quaternary sea-level highstands in the central and eastern Indian Ocean. A review: Global and Planetary Change 49, 121-138.

Yamato, P., Husson, L., Becker, T., Pedoja, K., 2013. Passive margin being squeezing in the mantle convection vice. Tectonics 32 (6), 1559-1570.

Yildirim, C., Melnick, D., Ballato, P., Schildgen, T.F., Echtler, H., Evren Erginal, A., Günec Kiyak, N., Strecker, M.R., 2013. Differential uplift along the northern margin of the Central Anatolian Plateau: inferences from marine terraces. Quat. Sci. Rev. 87, 12-28.

Yokoyama, Y., Esat, T.M., Lambeck, K., 2001a. Last glacial sea-level change deduced from uplifted coral terraces of Huon Peninsula, Papua New Guinea. Quat. Int. 83-85, 275-283.

Yokoyama, Y., Esat, T.M., Lambeck, K., 2001b. Coupled climate and sea level changes deduced from Huon Peninsula coral terraces of the last ice age. Earth Planet. Sci. Lett. 193, 579-587.

Yokoyama, Y., Purcell, A., Lambeck, K., Johnston, P., 2001c. Shore-line reconstruction around Australia during the Last Glacial Maximum and Late Glacial Stage. Quat. Int. 83, 9-18.

Zazo, C., 1999. Interglacial sea levels. Quat. Int. 55, 101-113.

Zazo, C., Goy, J.L., Dabrio, C.J., Bardají, T., Hillaire-Marcel, C., Ghaleb, B., González-Delgado, -Á., Soler, V., 2003. Pleistocene raised marine terraces of the Spanish Mediterranean and Atlantic coasts: records of coastal uplift, sea-level highstands and climate changes. Mar. Geol. 194, 103-133.

Zeuner, F.E., 1952. Pleistocene Shore-lines. Int. J. Earth Sci. 40, 39-50. 